Cochrane Database of Systematic Reviews

\title{
Second-line systemic therapy for metastatic colorectal cancer
} (Review)

Mocellin S, Baretta Z, Roqué i Figuls M, Solà I, Martin-Richard M, Hallum S, Bonfill Cosp X

Mocellin S, Baretta Z, Roqué i Figuls M, Solà I, Martin-Richard M, Hallum S, Bonfill Cosp X.

Second-line systemic therapy for metastatic colorectal cancer.

Cochrane Database of Systematic Reviews 2017, Issue 1. Art. No.: CD006875.

DOI: 10.1002/14651858.CD006875.pub3. 
TABLE OF CONTENTS

HEADER 1

ABSTRACT

PLAIN LANGUAGE SUMMARY

SUMMARY OF FINDINGS

BACKGROUND

OBJECTIVES

METHODS

Figure 1.

Figure 2.

RESULTS

Figure 3.

Figure 4.

Figure 5.

Figure 6.

Figure 7.

Figure 8.

Figure 9.

Figure 10.

DISCUSSION

AUTHORS' CONCLUSIONS

ACKNOWLEDGEMENTS

REFERENCES

CHARACTERISTICS OF STUDIES

DATA AND ANALYSES

Analysis 1.1. Comparison 1 All, Outcome 1 Overall survival (OS)_modern chemotherapy (CTX) vs 5-fluorouracil (5FU).

Analysis 1.2. Comparison 1 All, Outcome 2 Progression-free survival (PFS)_modern CTX vs 5FU.

Analysis 1.3. Comparison 1 All, Outcome 3 Overall response rate (ORR)_modern CTX vs 5FU.

Analysis 1.4. Comparison 1 All, Outcome 4 Serious adverse events (SAE)_modern CTX vs 5FU.

Analysis 1.5. Comparison 1 All, Outcome 5 OS_irino combination (combo).

Analysis 1.6. Comparison 1 All, Outcome 6 PFS_irino combo.

Analysis 1.7. Comparison 1 All, Outcome 7 ORR_irino combo.

Analysis 1.8. Comparison 1 All, Outcome 8 SAE_irino combo.

Analysis 1.9. Comparison 1 All, Outcome 9 OS_bevacizumab (beva) combo.

Analysis 1.10. Comparison 1 All, Outcome 10 PFS_beva combo.

Analysis 1.11. Comparison 1 All, Outcome 11 ORR_beva combo.

Analysis 1.12. Comparison 1 All, Outcome 12 SAE_beva combo.

Analysis 1.13. Comparison 1 All, Outcome 13 OS_FOLFIRI targeted.

Analysis 1.14. Comparison 1 All, Outcome 14 PFS_FOLFIRI targeted.

Analysis 1.15. Comparison 1 All, Outcome 15 ORR_FOLFIRI targeted.

Analysis 1.16. Comparison 1 All, Outcome 16 SAE_FOLFIRI targeted.

Analysis 1.17. Comparison 1 All, Outcome 17 OS_FOLFOX targeted.

Analysis 1.18. Comparison 1 All, Outcome 18 PFS_FOLFOX targeted.

Analysis 1.19. Comparison 1 All, Outcome 19 ORR_FOLFOX targeted.

Analysis 1.20. Comparison 1 All, Outcome 20 SAE_FOLFOX targeted.

Analysis 1.21. Comparison 1 All, Outcome 21 OS_irino fraction.

Analysis 1.22. Comparison 1 All, Outcome 22 PFS_irino fraction.

Analysis 1.23. Comparison 1 All, Outcome 23 ORR_irino fraction.

Analysis 1.24. Comparison 1 All, Outcome 24 SAE_irino fraction.

Analysis 1.25. Comparison 1 All, Outcome 25 OS_FOLFIRI + beva vs other targeted.

Analysis 1.26. Comparison 1 All, Outcome 26 PFS_FOLFIRI + beva vs other targeted.

Analysis 1.27. Comparison 1 All, Outcome 27 ORR_FOLFIRI + beva vs other targeted. 
Analysis 1.28. Comparison 1 All, Outcome 28 SAE_FOLFIRI + beva vs other targeted.

Analysis 1.29. Comparison 1 All, Outcome 29 OS_FOLFOX + beva vs other targeted.

Analysis 1.30. Comparison 1 All, Outcome 30 PFS_FOLFOX + beva vs other targeted.

Analysis 1.31. Comparison 1 All, Outcome 31 ORR_FOLFOX + beva vs other targeted.

Analysis 1.32. Comparison 1 All, Outcome 32 SAE_FOLFOX + beva vs other targeted.

ADDITIONAL TABLES

APPENDICES

WHAT'S NEW

HISTORY

CONTRIBUTIONS OF AUTHORS

DECLARATIONS OF INTEREST

SOURCES OF SUPPORT 
[Intervention Review]

\section{Second-line systemic therapy for metastatic colorectal cancer}

Simone Mocellin1,2, Zora Baretta 3 , Marta Roqué i Figuls ${ }^{4}$, Ivan Solà5, Marta Martin-Richard6, Sara Hallum ${ }^{7}$, Xavier Bonfill Cosp 4

1Department of Surgery, Oncology and Gastroenterology, University of Padova, Padova, Italy. ${ }^{2}$ Istituto Oncologico Veneto, IOVIRCCS, Padova, Italy. ${ }^{3}$ U.O.C. di Oncologia ULSS5 Ovest Vicentino, Ospedale di Montecchio, Vicenza, Italy. ${ }^{4}$ beroamerican Cochrane Centre - Biomedical Research Institute Sant Pau (IIB Sant Pau), CIBER Epidemiología y Salud Pública (CIBERESP), Barcelona, Spain. 5Iberoamerican Cochrane Centre - Biomedical Research Institute Sant Pau (IIB Sant Pau), CIBER Epidemiología y Salud Pública (CIBERESP) - Universitat Autònoma de Barcelona, Barcelona, Spain. ${ }^{6}$ Clinical Oncology, Hospital de la Santa Creu i Sant Pau, Barcelona, Spain. ${ }^{7}$ Cochrane Colorectal Cancer Group, Cochrane, Copenhagen, Denmark

Contact address: Simone Mocellin, Department of Surgery, Oncology and Gastroenterology, University of Padova, Via Giustiniani 2 , Padova, Veneto, 35128, Italy.simone.mocellin@unipd.it, mocellins@hotmail.com.

Editorial group: Cochrane Colorectal Cancer Group.

Publication status and date: Edited (conclusions changed), published in Issue 1, 2017.

Citation: Mocellin S, Baretta Z, Roqué i Figuls M, Solà I, Martin-Richard M, Hallum S, Bonfill Cosp X. Second-line systemic therapy for metastatic colorectal cancer. Cochrane Database of Systematic Reviews 2017, Issue 1. Art. No.: CD006875. DOI: 10.1002/14651858.CD006875.pub3.

Copyright @ 2017 The Cochrane Collaboration. Published by John Wiley \& Sons, Ltd.

\section{A B S T R A C T}

\section{Background}

The therapeutic management of people with metastatic colorectal cancer (CRC) who did not respond to first-line treatment represents a formidable challenge.

\section{Objectives}

To determine the efficacy and toxicity of second-line systemic therapy in people with metastatic CRC.

\section{Search methods}

We searched the Cochrane Central Register of Controlled Trials (CENTRAL) (the Cochrane Library 2016, Issue 4), Ovid MEDLINE (1950 to May 2016), Ovid MEDLINE In-process \& Other Non-Indexed Citations (1946 to May 2016) and Ovid Embase (1974 to May 2016). There were no language or date of publication restrictions.

\section{Selection criteria}

Randomized controlled trials (RCTs) assessing the efficacy (survival, tumour response) and toxicity (incidence of severe adverse effects (SAEs)) of second-line systemic therapy (single or combined treatment with any anticancer drug, at any dose and number of cycles) in people with metastatic CRC that progressed, recurred or did not respond to first-line systemic therapy.

\section{Data collection and analysis}

Authors performed a descriptive analysis of each included RCT in terms of primary (survival) and secondary (tumour response, toxicity) endpoints. In the light of the variety of drug regimens tested in the included trials, we could carry out meta-analysis considering classes of (rather than single) anticancer regimens; to this aim, we applied the random-effects model to pool the data. We used hazard ratios (HRs) and risk ratios (RRs) to describe the strength of the association for survival (overall (OS) and progression-free survival (PFS)) and dichotomous (overall response rate (ORR) and SAE rate) data, respectively, with 95\% confidence intervals (CI). 


\section{Main results}

Thirty-four RCTs (enrolling 13,787 participants) fulfilled the eligibility criteria. Available evidence enabled us to address multiple clinical issues regarding the survival effects of second-line systemic therapy of people with metastatic CRC.

1. Chemotherapy (irinotecan) was more effective than best supportive care (HR for OS: $0.58,95 \% \mathrm{Cl} 0.43$ to $0.80 ; 1$ RCT; moderate-quality evidence); 2. modern chemotherapy (FOLFOX (5-fluorouracil plus leucovorin plus oxaliplatin), irinotecan) is more effective than outdated chemotherapy (5-fluorouracil) (HR for PFS: $0.59,95 \% \mathrm{Cl} 0.49$ to $0.73 ; 2 \mathrm{RCTs}$; high-quality evidence) (HR for $0 \mathrm{~S}$ : $0.69,95 \% \mathrm{CI} 0.51$ to 0.94 ; 1 RCT; moderate-quality evidence); 3 . irinotecan-based combinations were more effective than irinotecan alone (HR for PFS: $0.68,95 \%$ $\mathrm{Cl} 0.60$ to 0.76 ; 6 RCTs; moderate-quality evidence); 4. targeted agents improved the efficacy of conventional chemotherapy both when considered together (HR for OS: $0.84,95 \% \mathrm{Cl} 0.77$ to $0.91 ; 6 \mathrm{RCTs}$; high-quality evidence) and when bevacizumab was used alone (HR for PFS: $0.67,95 \% \mathrm{Cl} 0.60$ to $0.75 ; 4$ RCTs; high-quality evidence).

With regard to secondary endpoints, tumour response rates generally paralleled the survival results; moreover, higher anticancer efficacy was generally associated with worse treatment-related toxicity, with the important exception of bevacizumab-containing regimens, where the addition of the targeted agent to chemotherapy did not result in a significant increase in the rate of SAE. Finally, we found that oral (instead of intravenous) fluoropyrimidines significantly reduced the incidence of adverse effects (without compromising efficacy) in people treated with oxaliplatin-based regimens.

We could not draw any conclusions on other debated aspects in this field of oncology, such as ranking of treatments (not all possible comparisons have been tested and many comparisons were based on single trials enrolling a small number of participants) and quality of life (virtually no data available).

\section{Authors' conclusions}

Systemic therapy offers a survival benefit to people with metastatic CRC who did not respond to first-line treatment, especially when targeted agents are combined with conventional chemotherapeutic drugs. Further research is needed to define the optimal regimen and to identify people who most benefit from each treatment.

\section{PLAIN LANGUAGE SUMMARY}

\section{Second-line therapy can increase survival of people with metastatic colorectal cancer who did not respond to a first treatment}

\section{Review question}

We reviewed the ability of chemotherapy drugs (medicines used to treat cancer) to reduce tumour size and improve survival in people with metastatic colorectal cancer who had not responded to a prior treatment. We also looked at the side effects caused by the different drug regimens.

\section{Background}

People with metastatic colorectal cancer (cancer that has spread to sites other than the colon) and whose disease had progressed despite one prior chemotherapy (first-line treatment) treatment, and who can be offered a second therapy (second-line treatment) with the aim of improving their poor outcome (prognosis). The treatment regimens compared were systemic (administered intravenously (through a vein)).

\section{Study characteristics}

The evidence is current to May 2016. In this updated review, we identified 34 clinical trials that compared second-line therapy with either no chemotherapy (best supportive care) or an alternative second-line therapy, so addressing the issue of second-line therapy performance in people with metastatic colorectal cancer.

\section{Main results}

Available evidence seemed to support the use of second-line therapy because it improved survival expectations as compared to best supportive care, although this was reported in only one small trial and the result would need to be confirmed in further research. Moreover, we found that modern chemotherapy regimens were more effective than older ones that contained a drug called 5-fluorouracil, that combination chemotherapy was more effective than single agent chemotherapy and that targeted agents (so called 'smart drugs' that attack the cancer cells and do little damage to normal cells) increased the effectiveness of conventional chemotherapy. Generally, toxicity increased as effectiveness increased.

\section{Quality of the evidence}

The main conclusions of this review were based on moderate to high quality evidence. When the quality of the evidence was considered low or moderate, this was generally due to inconsistency in the main results (i.e. the result for progression-free survival (time from the start of second-line treatment to progression of the cancer) was not confirmed by overall survival (time from the start of second-line treatment to death from any cause)) and the low numbers of participants included in the analyses. Nevertheless, it should be remembered that 
progression-free survival nowadays is considered a reliable surrogate of overall survival (which includes all deaths, not just cancer-related, and requires longer follow-up to obtain an accurate estimate) in the setting of second-line therapy for metastatic colorectal cancer. Most of the trials did not report quality of life, which prevented us formally investigating the balance between survival benefits provided by second-line systemic therapy and treatment-related toxicity. 
SUMMARY OF FINDINGS

Summary of findings for the main comparison. Modern chemotherapy regimens compared with 5-flourouracil

Modern chemotherapy regimens compared with 5-fluorouracil

Patient or population: people with metastatic CRC

Settings: second-line treatment

Intervention: modern CTX (FOLFOX or irinotecan)

Comparison: $5 \mathrm{FU}$

\begin{tabular}{|c|c|c|c|c|c|c|}
\hline \multirow[t]{3}{*}{ Outcomes } & \multicolumn{2}{|c|}{$\begin{array}{l}\text { Illustrative comparative risks* } \\
(95 \% \mathrm{CI})\end{array}$} & \multirow[t]{3}{*}{$\begin{array}{l}\text { Relative effect } \\
(95 \% \mathrm{Cl})\end{array}$} & \multirow[t]{3}{*}{$\begin{array}{l}\text { No of partici- } \\
\text { pants } \\
\text { (studies) }\end{array}$} & \multirow[t]{3}{*}{$\begin{array}{l}\text { Quality of the evi- } \\
\text { dence } \\
\text { (GRADE) }\end{array}$} & \multirow[t]{3}{*}{ Comments } \\
\hline & Assumed risk & Corresponding risk & & & & \\
\hline & $5 F U$ & Modern CTX & & & & \\
\hline Overall survival & 800 per 1000 & $\begin{array}{l}671 \text { per } 1000 \\
(560 \text { to } 780)\end{array}$ & $\begin{array}{l}\text { HR } 0.69 \\
\text { (0.51 to } 0.94)\end{array}$ & $\begin{array}{l}167 \\
(1 \mathrm{RCT})\end{array}$ & $\begin{array}{l}+++- \\
\text { Moderate }\end{array}$ & $\begin{array}{l}\text { Reason for downgrad- } \\
\text { ing: only } 1 \text { trial avail- } \\
\text { able }\end{array}$ \\
\hline $\begin{array}{l}\text { Progression-free } \\
\text { survival }\end{array}$ & 900 per 1000 & $\begin{array}{l}749 \text { per } 1000 \\
\text { (669 to } 818)\end{array}$ & $\begin{array}{l}\text { HR } 0.59 \\
\text { (0.49 to } 0.73 \text { ) }\end{array}$ & $\begin{array}{l}470 \\
(2 \mathrm{RCTs})\end{array}$ & $\begin{array}{l}++++ \\
\text { High }\end{array}$ & - \\
\hline $\begin{array}{l}\text { Overall tumour re- } \\
\text { sponse }\end{array}$ & 34 per 1000 & $\begin{array}{l}99 \text { per } 1000 \\
(50 \text { to } 197)\end{array}$ & $\begin{array}{l}\text { RR } 2.96 \\
(1.66 \text { to } 5.27)\end{array}$ & $\begin{array}{l}866 \\
\text { (3 RCTs) }\end{array}$ & $\begin{array}{l}++++ \\
\text { High }\end{array}$ & - \\
\hline
\end{tabular}

${ }^{*}$ The basis for the assumed risk (median control group risk across studies) for survival outcomes is provided in footnotes. The corresponding risk (and its $95 \%$ confidence interval) is based on the assumed risk in the comparison group and the relative effect of the intervention (and its $95 \% \mathrm{Cl}$ ).

5FU: 5-fluorouracil; CI: confidence interval; CRC: colorectal cancer; CTX: chemotherapy; FOLFOX: fluorouracil + oxaliplatin + leucovorin; HR: hazard ratio; RCT: randomized controlled trial; RR: risk ratio.

GRADE Working Group grades of evidence

High quality: Further research is very unlikely to change our confidence in the estimate of effect.

Moderate quality: Further research is likely to have an important impact on our confidence in the estimate of effect and may change the estimate. 
Low quality: Further research is very likely to have an important impact on our confidence in the estimate of effect and is likely to change the estimate. Very low quality: We are very uncertain about the estimate.

${ }^{\star}$ Assumed risk in controls: 1 -year progression-free survival rate $=10 \%$; 1 -year overall survival rate $=20 \%$.

Summary of findings 2 . Chemotherapy + bevacizumab compared with chemotherapy

Chemotherapy + bevacizumab compared with chemotherapy

Patient or population: people with metastatic CRC

Settings: second-line treatment

Intervention: bevacizumab $+\mathrm{CTX}$

Comparison: CTX

\begin{tabular}{|c|c|c|c|c|c|c|}
\hline \multirow[t]{3}{*}{ Outcomes } & \multicolumn{2}{|c|}{ Illustrative comparative risks* $(95 \% \mathrm{CI})$} & \multirow{3}{*}{$\begin{array}{l}\text { Relative effect } \\
(95 \% \mathrm{CI})\end{array}$} & \multirow{3}{*}{$\begin{array}{l}\text { No of partici- } \\
\text { pants } \\
\text { (studies) }\end{array}$} & \multirow{3}{*}{$\begin{array}{l}\text { Quality of the } \\
\text { evidence } \\
\text { (GRADE) }\end{array}$} & \multirow[t]{3}{*}{ Comments } \\
\hline & Assumed risk & Corresponding risk & & & & \\
\hline & CTX & Bevacizumab + CTX & & & & \\
\hline Overall survival & 600 per 1000 & $\begin{array}{l}515 \text { per } 1000 \\
\text { (474 to } 554 \text { ) }\end{array}$ & $\begin{array}{l}\text { HR } 0.79 \\
(0.70 \text { to } 0.88)\end{array}$ & $\begin{array}{l}1723 \\
\text { (4 RCTs) }\end{array}$ & $\begin{array}{l}++++ \\
\text { High }\end{array}$ & - \\
\hline $\begin{array}{l}\text { Progression-free } \\
\text { survival }\end{array}$ & 850 per 1000 & $\begin{array}{l}720 \text { per } 1000 \\
(680 \text { to } 759)\end{array}$ & $\begin{array}{l}\text { HR } 0.67 \\
(0.60 \text { to } 0.75)\end{array}$ & $\begin{array}{l}1723 \\
\text { (4 RCTs) }\end{array}$ & $\begin{array}{l}+++ \\
\text { High }\end{array}$ & - \\
\hline $\begin{array}{l}\text { Overall tumour re- } \\
\text { sponse }\end{array}$ & 92 per 1000 & $\begin{array}{l}158 \text { per } 1000 \\
\text { (113 to } 223 \text { ) }\end{array}$ & $\begin{array}{l}\text { RR } 1.72 \\
\text { (1.23 to } 2.43 \text { ) }\end{array}$ & $\begin{array}{l}1723 \\
\text { (4 RCTs) }\end{array}$ & $\begin{array}{l}++++ \\
\text { High }\end{array}$ & - \\
\hline $\begin{array}{l}\text { Severe adverse ef- } \\
\text { fects }\end{array}$ & 585 per 1000 & $\begin{array}{l}626 \text { per } 1000 \\
(544 \text { to } 731)\end{array}$ & $\begin{array}{l}\text { RR } 1.07 \\
\text { (0.93 to } 1.25 \text { ) }\end{array}$ & $\begin{array}{l}1708 \\
\text { (4 RCTs) }\end{array}$ & $\begin{array}{l}++-- \\
\text { Low }\end{array}$ & $\begin{array}{l}\text { Reasons for down- } \\
\text { grading: } 95 \% \mathrm{Cl} \\
\text { crossed the null } \\
\text { value and be- } \\
\text { tween-study hetero- } \\
\text { geneity }\end{array}$ \\
\hline
\end{tabular}

${ }^{\star}$ The basis for the assumed risk (median control group risk across studies) for survival outcomes is provided in footnotes. The corresponding risk (and its $95 \%$ confidence interval) is based on the assumed risk in the comparison group and the relative effect of the intervention (and its $95 \% \mathrm{CI}$ ). 


\begin{tabular}{|c|c|c|c|c|c|c|}
\hline \multicolumn{7}{|c|}{$\begin{array}{l}\text { GRADE Working Group grades of evidence } \\
\text { High quality: Further research is very unlikely to change our confidence in the estimate of effect. } \\
\text { Moderate quality: Further research is likely to have an important impact on our confidence in the estimate of effect and may change the estimate. } \\
\text { Low quality: Further research is very likely to have an important impact on our confidence in the estimate of effect and is likely to change the estimate. } \\
\text { Very low quality: We are very uncertain about the estimate. }\end{array}$} \\
\hline \multicolumn{7}{|c|}{ * Assumed risk in controls: 1 -year progression-free survival rate $=15 \%$; 1 -year overall survival rate $=40 \%$. } \\
\hline \multicolumn{7}{|c|}{ Irinotecan-based regimens compared with irinotecan } \\
\hline \multicolumn{7}{|c|}{$\begin{array}{l}\text { Patient or population: people with metastatic CRC } \\
\text { Settings: second-line treatment } \\
\text { Intervention: irinotecan-based combination CTX } \\
\text { Comparison: irinotecan }\end{array}$} \\
\hline \multirow[t]{3}{*}{ Outcomes } & \multicolumn{2}{|c|}{$\begin{array}{l}\text { Illustrative comparative risks }{ }^{\star}(95 \% \\
\mathrm{Cl})\end{array}$} & \multirow[t]{3}{*}{$\begin{array}{l}\text { Relative effect } \\
(95 \% \mathrm{CI})\end{array}$} & \multirow{3}{*}{$\begin{array}{l}\text { No of partici- } \\
\text { pants } \\
\text { (studies) }\end{array}$} & \multirow{3}{*}{$\begin{array}{l}\text { Quality of the } \\
\text { evidence } \\
\text { (GRADE) }\end{array}$} & \multirow[t]{3}{*}{ Comments } \\
\hline & Assumed risk & Corresponding risk & & & & \\
\hline & Irinotecan & $\begin{array}{l}\text { Irinotecan combi- } \\
\text { nation }\end{array}$ & & & & \\
\hline $\begin{array}{l}\text { Progres- } \\
\text { sion-free sur- } \\
\text { vival }\end{array}$ & 850 per 1000 & $\begin{array}{l}725 \text { per } 1000 \\
(680 \text { to } 764)\end{array}$ & $\begin{array}{l}\text { HR } 0.68 \\
(0.60 \text { to } 0.76)\end{array}$ & $\begin{array}{l}2615 \\
\text { (6 RCTs) }\end{array}$ & $\begin{array}{l}+++- \\
\text { Moderate }\end{array}$ & $\begin{array}{l}\text { Reason for downgrading: results inconsistency } \\
\text { (progression-free survival findings not supported } \\
\text { by overall survival findings) }\end{array}$ \\
\hline Overall survival & 600 per 1000 & $\begin{array}{l}565 \text { per } 1000 \\
\text { (515 to } 614)\end{array}$ & $\begin{array}{l}\text { HR } 0.91 \text { ( } 0.79 \text { to } \\
1.04 \text { ) }\end{array}$ & $\begin{array}{l}2615 \\
\text { (6 RCTs) }\end{array}$ & $\begin{array}{l}++-- \\
\text { Low }\end{array}$ & $\begin{array}{l}\text { Reasons for downgrading: results imprecision } \\
\text { ( } 95 \% \mathrm{Cl} \text { crossed the null value) and inconsistency } \\
\text { (moderate between-study heterogeneity; overall } \\
\text { survival findings not supported by progression-free } \\
\text { survival findings) }\end{array}$ \\
\hline $\begin{array}{l}\text { Overall tumour } \\
\text { response }\end{array}$ & 67 per 1000 & $\begin{array}{l}192 \text { per } 1000 \\
\text { (141 to } 263)\end{array}$ & $\begin{array}{l}\text { RR } 2.87 \\
\text { (2.10 to } 3.93 \text { ) }\end{array}$ & $\begin{array}{l}2577 \\
\text { (6 RCTs) }\end{array}$ & $\begin{array}{l}++++ \\
\text { High }\end{array}$ & - \\
\hline
\end{tabular}




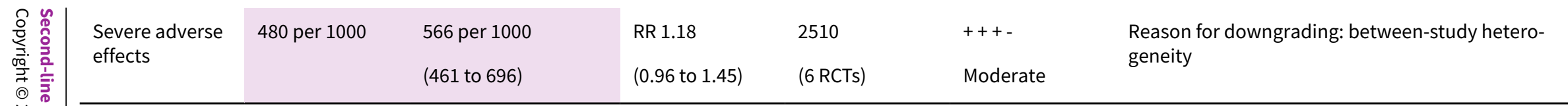

${ }^{\star}$ The basis for the assumed risk (median control group risk across studies) for survival outcomes is provided in footnotes. The corresponding risk (and its $95 \%$ confidence interval) is based on the assumed risk in the comparison group and the relative effect of the intervention (and its $95 \% \mathrm{Cl}$ ).

Cl: confidence interval; CRC: colorectal cancer; CTX: chemotherapy; HR: hazard ratio; RCT: randomized controlled trial; RR: risk ratio.

GRADE Working Group grades of evidence

High quality: Further research is very unlikely to change our confidence in the estimate of effect.

Moderate quality: Further research is likely to have an important impact on our confidence in the estimate of effect and may change the estimate.

Low quality: Further research is very likely to have an important impact on our confidence in the estimate of effect and is likely to change the estimate.

Very low quality: We are very uncertain about the estimate.

* Assumed risk in controls: 1-year progression-free survival rate $=15 \%$; 1 -year overall survival rate $=40 \%$.

\section{Summary of findings 4. Irinotecan + oxaliplatin compared with irinotecan}

\section{Irinotecan + oxaliplatin compared with irinotecan}

Patient or population: people with metastatic CRC

Settings: second-line treatment

Intervention: irinotecan + oxaliplatin (IROX)

Comparison: irinotecan

\begin{tabular}{|c|c|c|c|c|c|c|}
\hline \multirow[t]{2}{*}{ Outcomes } & \multicolumn{2}{|c|}{ Illustrative comparative risks ${ }^{\star}(95 \% \mathrm{Cl})$} & \multirow{2}{*}{$\begin{array}{l}\text { Relative effect } \\
(95 \% \mathrm{Cl})\end{array}$} & \multirow{2}{*}{$\begin{array}{l}\text { No of partici- } \\
\text { pants } \\
\text { (studies) }\end{array}$} & \multirow{2}{*}{$\begin{array}{l}\text { Quality of the } \\
\text { evidence } \\
\text { (GRADE) }\end{array}$} & \multirow[t]{2}{*}{ Comments } \\
\hline & Assumed risk & Corresponding risk & & & & \\
\hline \multirow[t]{2}{*}{ Overall survival } & 600 per 1000 & 511 per 1000 & HR 0.78 & 627 & +++- & Reason for downgrading: only 1 tria \\
\hline & & (459 to 562 ) & (0.67 to 0.90$)$ & $(1 \mathrm{RCT})$ & Moderate & \\
\hline \multirow{2}{*}{$\begin{array}{l}\text { Progres- } \\
\text { sion-free sur- } \\
\text { vival }\end{array}$} & 900 per 1000 & 749 per 1000 & HR 0.60 & 627 & +++ & Reason for downgrading: only 1 tria \\
\hline & & (718 to 781 ) & (0.55 to 0.66$)$ & (1 RCT) & Moderate & \\
\hline $\begin{array}{l}\text { Overall tumour } \\
\text { response }\end{array}$ & 221 per 1000 & 658 per 1000 & RR 2.98 & 627 & +++- & Reason for downgrading: only 1 tria \\
\hline
\end{tabular}




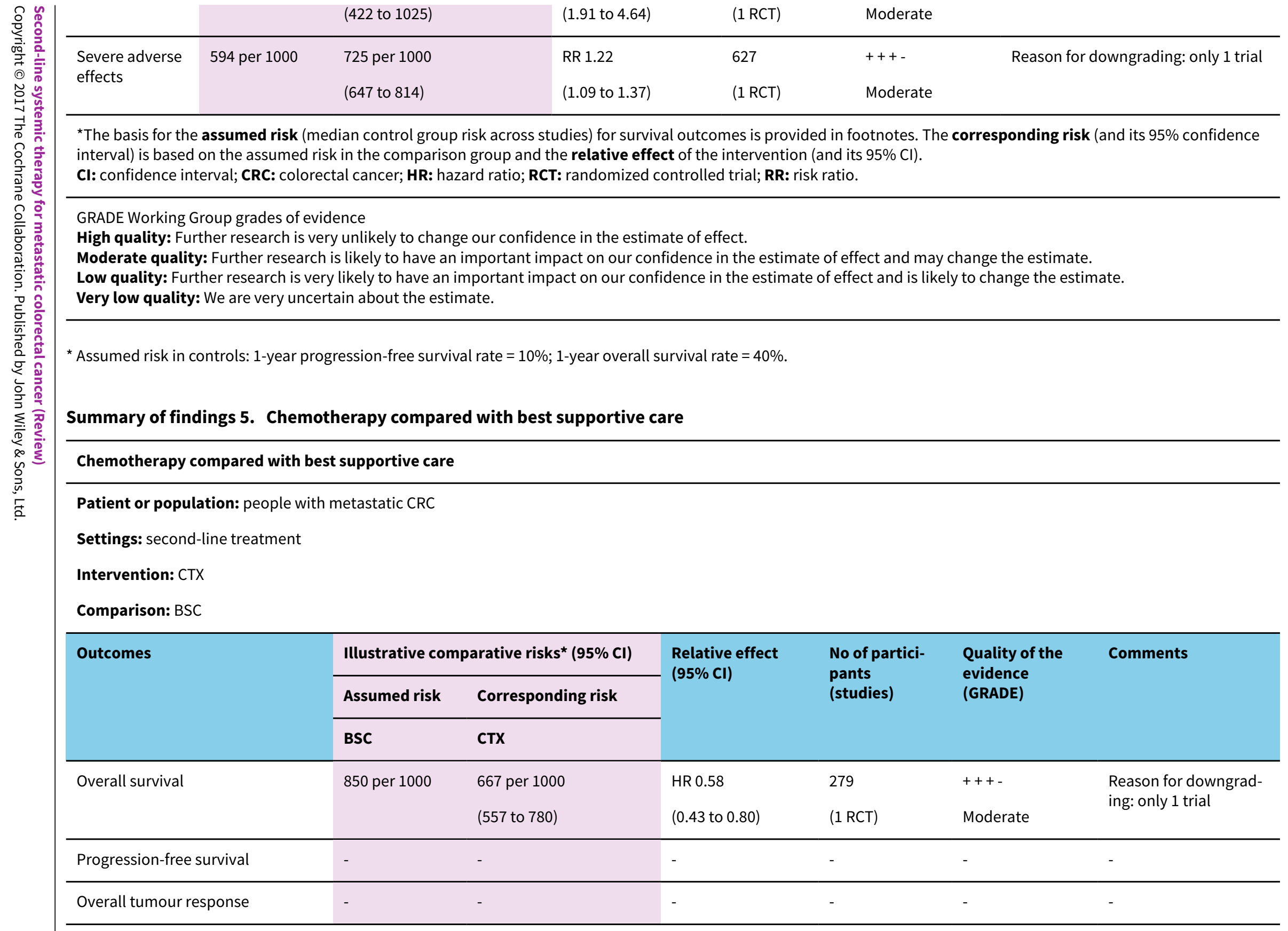




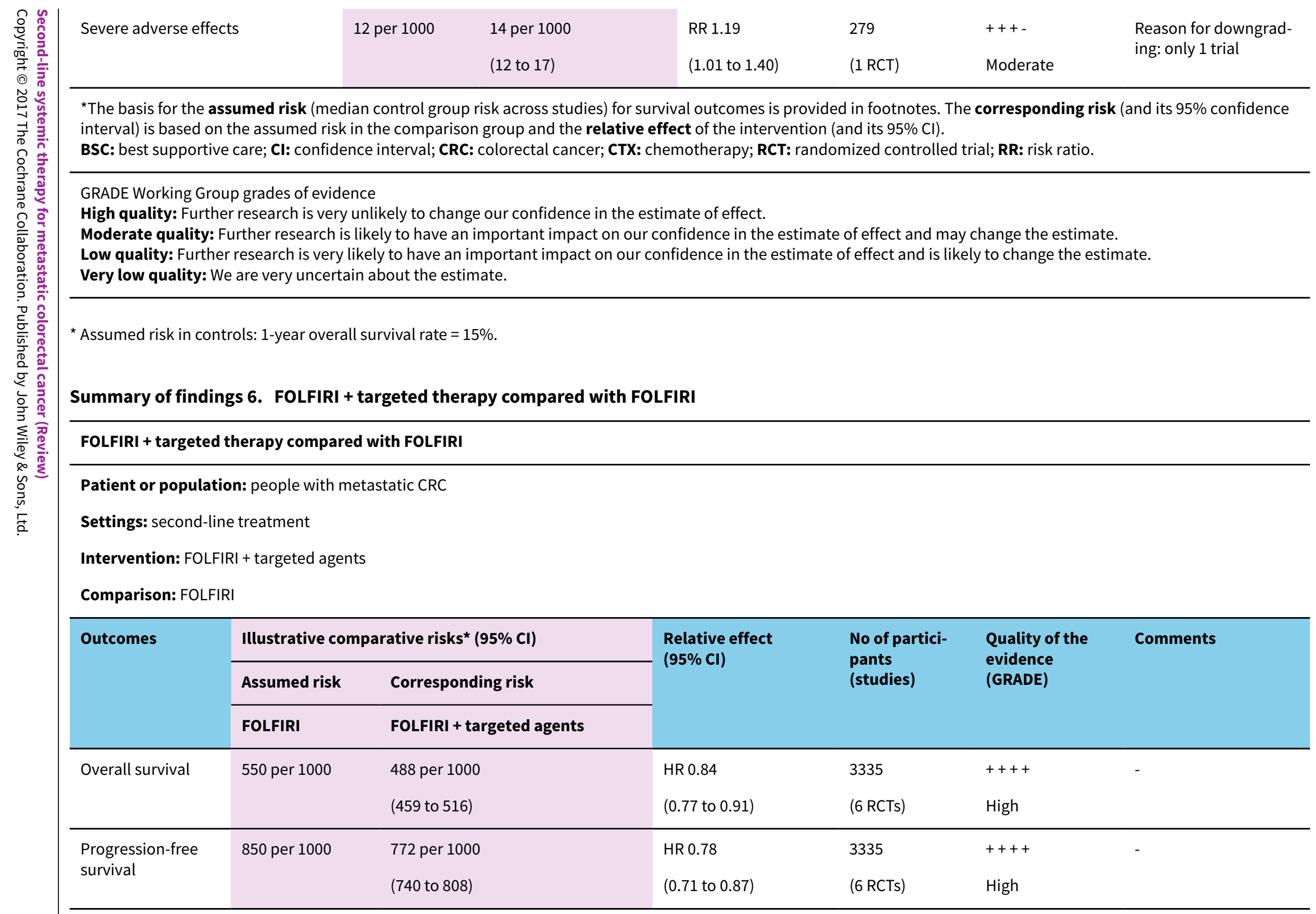




\begin{tabular}{|c|c|c|c|c|c|c|}
\hline $\begin{array}{l}\text { Overall tumour re- } \\
\text { sponse }\end{array}$ & 112 per 1000 & $\begin{array}{l}232 \text { per } 1000 \\
(147 \text { to } 367)\end{array}$ & $\begin{array}{l}\text { RR } 2.07 \\
(1.31 \text { to } 3.28)\end{array}$ & $\begin{array}{l}3192 \\
\text { (6 RCTs) }\end{array}$ & $\begin{array}{l}+++- \\
\text { Moderate }\end{array}$ & $\begin{array}{l}\text { Reason for downgrad- } \\
\text { ing: between-study } \\
\text { heterogeneity }\end{array}$ \\
\hline $\begin{array}{l}\text { Severe adverse ef- } \\
\text { fects }\end{array}$ & 494 per 1000 & $\begin{array}{l}642 \text { per } 1000 \\
(578 \text { to } 716)\end{array}$ & $\begin{array}{l}\text { RR } 1.30 \\
\text { (1.17 to } 1.45 \text { ) }\end{array}$ & $\begin{array}{l}3341 \\
\text { (6 RCTs) }\end{array}$ & $\begin{array}{l}+++- \\
\text { Moderate }\end{array}$ & $\begin{array}{l}\text { Reason for downgrad- } \\
\text { ing: between-study } \\
\text { heterogeneity }\end{array}$ \\
\hline
\end{tabular}

${ }^{*}$ The basis for the assumed risk (median control group risk across studies) for survival outcomes is provided in footnotes. The corresponding risk (and its $95 \%$ confidence interval) is based on the assumed risk in the comparison group and the relative effect of the intervention (and its $95 \% \mathrm{Cl}$ ).

CI: confidence interval; CRC: colorectal cancer; FOLFIRI: fluorouracil + irinotecan + leucovorin; HR: hazard ratio; RCT: randomized controlled trial; RR: risk ratio.

GRADE Working Group grades of evidence

High quality: Further research is very unlikely to change our confidence in the estimate of effect.

Moderate quality: Further research is likely to have an important impact on our confidence in the estimate of effect and may change the estimate.

Low quality: Further research is very likely to have an important impact on our confidence in the estimate of effect and is likely to change the estimate.

Very low quality: We are very uncertain about the estimate.

${ }^{*}$ Assumed risk in controls: 1 -year progression-free survival rate $=15 \%$; 1 -year overall survival rate $=45 \%$.

Summary of findings 7. FOLFOX + targeted therapy compared with FOLFOX

\section{FOLFOX + targeted therapy compared with FOLFOX}

Patient or population: people with metastatic CRC

Settings: second-line treatment

Intervention: FOLFOX + targeted agents

Comparison: FOLFOX

\begin{tabular}{|c|c|c|c|c|c|c|}
\hline \multirow[t]{3}{*}{ Outcomes } & \multicolumn{2}{|c|}{$\begin{array}{l}\text { Illustrative comparative risks* }(95 \% \\
\mathrm{Cl})\end{array}$} & \multirow[t]{3}{*}{$\begin{array}{l}\text { Relative effect } \\
(95 \% \mathrm{Cl})\end{array}$} & \multirow{3}{*}{$\begin{array}{l}\text { No of partici- } \\
\text { pants } \\
\text { (studies) }\end{array}$} & \multirow{3}{*}{$\begin{array}{l}\text { Quality of the } \\
\text { evidence } \\
\text { (GRADE) }\end{array}$} & \multirow[t]{3}{*}{ Comments } \\
\hline & Assumed risk & Corresponding risk & & & & \\
\hline & FOLFOX & $\begin{array}{l}\text { FOLFOX }+ \text { targeted } \\
\text { agents }\end{array}$ & & & & \\
\hline Overall survival & 600 per 1000 & 553 per 1000 & $\begin{array}{l}\text { HR } 0.92 \text { (0.82 to } \\
1.04)\end{array}$ & 1432 & +-- & $\begin{array}{l}\text { Reasons for downgrading: results imprecision } \\
\text { ( } 95 \% \mathrm{Cl} \text { crosses the null value) and inconsistency }\end{array}$ \\
\hline
\end{tabular}




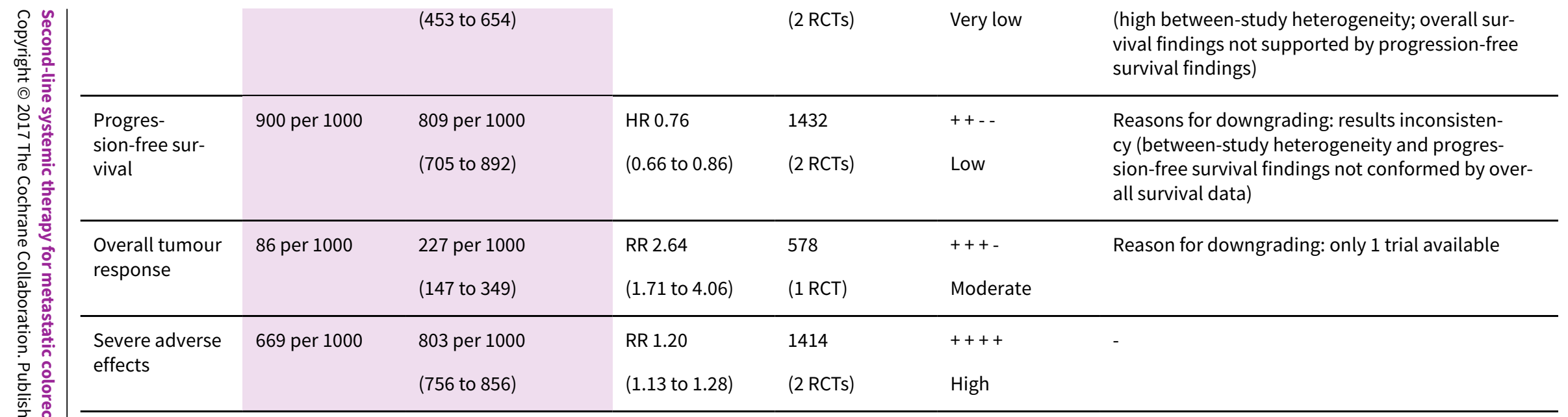

*The basis for the assumed risk (median control group risk across studies) is provided in footnotes. The corresponding risk (and its $95 \%$ confidence interval) is based on the assumed risk in the comparison group and the relative effect of the intervention (and its $95 \% \mathrm{Cl}$ ).

Cl: confidence interval; CRC: colorectal cancer; FOLFIRI: fluorouracil + irinotecan + leucovorin; HR: hazard ratio; RCT: randomized controlled trial; RR: risk ratio.

GRADE Working Group grades of evidence

High quality: Further research is very unlikely to change our confidence in the estimate of effect.

Moderate quality: Further research is likely to have an important impact on our confidence in the estimate of effect and may change the estimate.

Low quality: Further research is very likely to have an important impact on our confidence in the estimate of effect and is likely to change the estimate.

Very low quality: We are very uncertain about the estimate.

* Assumed risk in controls: 1-year progression-free survival rate $=10 \%$; 1 -year overall survival rate $=40 \%$.

\section{Summary of findings 8 . Irinotecan + targeted therapy compared with irinotecan}

\section{Irinotecan + targeted therapy compared with irinotecan}

Patient or population: people with metastatic CRC

Settings: second-line treatment

Intervention: irinotecan + targeted therapy

Comparison: irinotecan

\begin{tabular}{llllll}
\hline Outcomes & Illustrative comparative risks* $(95 \% \mathrm{CI})$ & $\begin{array}{l}\text { Relative effect } \\
(95 \% \mathrm{CI})\end{array}$ & $\begin{array}{l}\text { No of partici- } \\
\text { pants } \\
\text { (studies) }\end{array}$ & $\begin{array}{l}\text { Quality of the } \\
\text { evidence } \\
\text { (GRADE) }\end{array}$
\end{tabular}




\begin{tabular}{|c|c|c|c|c|c|c|}
\hline & Irinotecan & $\begin{array}{l}\text { Irinotecan + targeted } \\
\text { therapy }\end{array}$ & & & & \\
\hline Overall survival & 600 per 1000 & $\begin{array}{l}596 \text { per } 1000 \\
\text { (553 to } 603 \text { ) }\end{array}$ & $\begin{array}{l}\text { HR } 0.99 \\
\text { (0.88 to } 1.10)\end{array}$ & $\begin{array}{l}1758 \\
\text { (2 RCTs) }\end{array}$ & $\begin{array}{l}++-- \\
\text { Low }\end{array}$ & $\begin{array}{l}\text { Reasons for downgrading: results imprecision } \\
\text { ( } 95 \% \mathrm{Cl} \text { crosses the null value) and inconsisten- } \\
\text { cy (overall survival findings not conformed by } \\
\text { progression-free survival data) }\end{array}$ \\
\hline $\begin{array}{l}\text { Progres- } \\
\text { sion-free sur- } \\
\text { vival }\end{array}$ & 900 per 1000 & $\begin{array}{l}805 \text { per } 1000 \\
\text { (771 to } 838 \text { ) }\end{array}$ & $\begin{array}{l}\text { HR } 0.71 \\
\text { (0.64 to } 0.79 \text { ) }\end{array}$ & $\begin{array}{l}1758 \\
\text { (2 RCTs) }\end{array}$ & $\begin{array}{l}+++- \\
\text { Moderate }\end{array}$ & $\begin{array}{l}\text { Reason for downgrading: results inconsisten- } \\
\text { cy (progression-free survival findings not con- } \\
\text { formed by overall survival data) }\end{array}$ \\
\hline $\begin{array}{l}\text { Overall tumour } \\
\text { response }\end{array}$ & 61 per 1000 & $\begin{array}{l}206 \text { per } 1000 \\
\text { (154 to } 276)\end{array}$ & $\begin{array}{l}\text { RR } 3.38 \\
\text { (2.53 to } 4.52 \text { ) }\end{array}$ & $\begin{array}{l}1758 \\
\text { (2 RCTs) }\end{array}$ & $\begin{array}{l}++++ \\
\text { High }\end{array}$ & - \\
\hline $\begin{array}{l}\text { Severe adverse } \\
\text { effects }\end{array}$ & 425 per 1000 & $\begin{array}{l}612 \text { per } 1000 \\
\text { (557 to } 676 \text { ) }\end{array}$ & $\begin{array}{l}\text { RR } 1.44 \\
\text { (1.31 to } 1.59 \text { ) }\end{array}$ & $\begin{array}{l}1704 \\
\text { (2 RCTs) }\end{array}$ & $\begin{array}{l}++++ \\
\text { High }\end{array}$ & - \\
\hline
\end{tabular}

*The basis for the assumed risk (median control group risk across studies) for survival outcomes is provided in footnotes. The corresponding risk (and its $95 \%$ confidence interval) is based on the assumed risk in the comparison group and the relative effect of the intervention (and its $95 \% \mathrm{Cl}$ ).

Cl: confidence interval; CRC: colorectal cancer; HR: hazard ratio; RCT: randomized controlled trial; RR: risk ratio.

GRADE Working Group grades of evidence

High quality: Further research is very unlikely to change our confidence in the estimate of effect.

Moderate quality: Further research is likely to have an important impact on our confidence in the estimate of effect and may change the estimate.

Low quality: Further research is very likely to have an important impact on our confidence in the estimate of effect and is likely to change the estimate.

Very low quality: We are very uncertain about the estimate.

${ }^{*}$ Assumed risk in controls: 1 -year progression-free survival rate $=10 \%$; 1-year overall survival rate $=40 \%$. 


\section{B A C K G R O U N D}

\section{Description of the condition}

Colorectal cancer (CRC) is one of the most common causes of cancer and cancer death worldwide and the third cause in Western countries (Ferlay 2015; Torre 2015). The World Health Organization (WHO) estimates that there are about one million cases annually worldwide, with almost 500,000 deaths (WHO 2003). About $50 \%$ of all newly diagnosed people have metastatic disease at presentation (so called synchronous metastasis) or will ultimately develop metastatic disease (metachronous metastasis), regardless of treatment (Cunningham 1998; Cunningham 2010; Saunders 2006). Except for selected people with liver only resectable metastatic disease where radical surgery can be followed by long survival times (Adam 2012; Schmoll 2012), systemic treatment is the treatment of choice in metastatic disease since it has proved to be effective in prolonging survival (Best 2000; Cunningham 2010; Gustavsson 2015; Kirstein 2014; Schmoll 2012).

\section{Description of the intervention}

Until the introduction of irinotecan and oxaliplatin in 2000 , standard first-line chemotherapy treatment for metastatic CRC was based on regimens containing 5-fluorouracil (5FU) and leucovorin. Currently, the combination regimens FOLFOX (5FU plus leucovorin plus oxaliplatin) and FOLFIRI (5FU plus leucovorin plus irinotecan) are considered standard therapies in first-line treatment (Grothey 2006; NICE 2005). Moreover, so-called targeted therapies based on agents that selectively act on molecules that play a significant role in cancer progression (e.g. epidermal growth factor receptor (EGFR) and vascular endothelial growth factor (VEGF)) have further improved life expectancy (Kirstein 2014; Marques 2014). However, most (if not all) people with metastatic disease will eventually present clinical failure (i.e. disease recurrence or progression) or lack of response to first-line treatment, thus becoming potential candidates for second-line systemic therapy (Arnold 2013; Cunningham 2010; Goldberg 2006; Gustavsson 2015; Kirstein 2014; Marques 2014; Rougier 2005).

\section{Why it is important to do this review}

The performance (i.e. efficacy and toxicity) of second-line systemic therapy is unclear. In particular, there is uncertainty about the efficacy of chemotherapy in this population (as compared to observation/best supportive care), the role of targeted agents (e.g. whether or not they increase the efficacy of conventional chemotherapy), the optimal regimen in terms of type and number of anticancer agents and the schedule of treatment delivery. The purpose of this systematic review was to summarize the available evidence on the performance of second-line systemic therapy in people with distant metastatic CRC.

\section{O B JECTIVES}

To determine the efficacy and toxicity of second-line systemic therapy in people with metastatic CRC.

\section{METHODS}

\section{Criteria for considering studies for this review}

\section{Types of studies}

Randomized controlled trials (RCTs) in people with distant metastatic (or locally advanced unresectable) CRC, in which a second-line systemic therapy regimen is compared with placebo, best supportive care or another second-line systemic therapy regimen. Cluster-randomized trials and cross-over trials were not eligible.

\section{Types of participants}

People with distant metastatic or locally advanced unresectable CRC (that is, TNM stage IV disease) that had progressed, recurred or did not respond to first-line systemic therapy. People eligible for surgery (e.g. with resectable liver metastasis) were not included.

\section{Types of interventions}

Any second-line systemic therapy regimen (single agent or combinatory regimen). We considered the following comparisons:

- second-line systemic therapy versus control (placebo or best supportive care);

- comparisons of different second-line systemic therapy regimens.

\section{Types of outcome measures}

\section{Primary outcomes}

- Overall survival (OS, time from the start of second-line treatment to death by any cause).

- Progression-free survival (PFS, time from the start of second-line treatment to disease progression).

\section{Secondary outcomes}

- Overall tumour response rate (ORR (complete and partial response), according to WHO (WHO 1979), or Response Evaluation Criteria In Solid Tumours (RECIST) criteria (Therasse 2000)).

- Severe adverse events (SAE, treatment-related grade 3 to 5 toxicity in Common Terminology Criteria for Adverse Events (CTCAE) (CTCAE) scale, or equivalent).

- Quality of life (QoL, as assessed by dedicated questionnaires such as the European Organisation for Research and Treatment of Cancer (EORTC) QLQ-C30).

\section{Search methods for identification of studies}

\section{Electronic searches}

We conducted a comprehensive literature search to identify all published and unpublished RCTs applying no language or date of publication restrictions. We searched the following electronic databases:

- Cochrane Central Register of Controlled Trials (CENTRAL) (the Cochrane Library 2016, Issue 4) (Appendix 1);

- Ovid MEDLINE (1950 to May 2016) (Appendix 2);

- Ovid MEDLINE In-process \& Other Non-Indexed Citations (1946 to May 2016) (Appendix 3); and 
- Ovid EMBASE (1974 to May 2016) (Appendix 4).

We applied a sensitivity- and precision maximizing search filter to the MEDLINE search strategy in accordance with recommendations from Chapter 6 of the Cochrane Handbook for Systematic Reviews of Interventions (Higgins 2011).

\section{Searching other resources}

We checked the reference lists of relevant studies as well as those of both qualitative and quantitative reviews to identify additional trials.

Finally, we searched the following web-based electronic databases in May 2016: www.clinicaltrials.gov; www.clinicaltrialsregister.eu; www.eortc.org/clinical-trials, and www.cancerresearchuk.org.

\section{Data collection and analysis}

\section{Selection of studies}

Two authors (SM, ZB) independently screened the results of the bibliographic search, assessing studies against the inclusion criteria. We retrieved full copies of trial reports when necessary for a more thorough assessment. We resolved disagreements by discussion and consensus.

\section{Data extraction and management}

Two authors (SM, ZB) independently extracted the relevant data from the included trials. We resolved disagreements by discussion and consensus. We extracted information regarding trial quality, participants and disease features, study design and trial results. As regards trial findings, we retrieved and analyzed intention-totreat data. For survival data, for each comparison we extracted the corresponding hazard ratio (HR) (and its 95\% confidence interval $(\mathrm{Cl})$ ) relative to the experimental versus control arm; when these summary data were not reported in the study article, we calculated them from Kaplan-Meier survival curves (if available) as per Parmar 1998. For dichotomous data (tumour response and toxicity), we extracted events and total number of participants from both experimental and control arm.

In order to evaluate whether the number of participants included in a trial (or meta-analysis of trials) was adequate to draw robust conclusions (i.e. based on adequately powered analyses) regarding the lack of difference between two treatments, we calculated that the minimum sample size needed to get an $80 \%$ statistical power (considering an alpha level of significance of $5 \%$, a one-year survival rate in the control population of $20 \%$ and an expected HR of 0.75 ) was about 500 .

\section{Assessment of risk of bias in included studies}

Two authors (SM, ZB) independently assessed the risk of bias according to the Cochrane 'Risk of bias' tool within the following domains (Higgins 2011):

- random allocation generation;

- allocation concealment;

- blinding of participants and personnel;

- blinding of outcome assessment;

- incomplete outcome data;

- selective reporting bias; and

- other biases (see Appendix 5).

Criteria for judging as low, high or unclear risk of bias within each domain were classified based on the 'Risk of bias' assessment tool (see Appendix 5) from Chapter 8 of the Cochrane Handbook for Systematic Reviews of Interventions (Higgins 2011). We summarized the risk of bias for each included study in Figure 1 and Figure 2.

\section{Figure 1.}

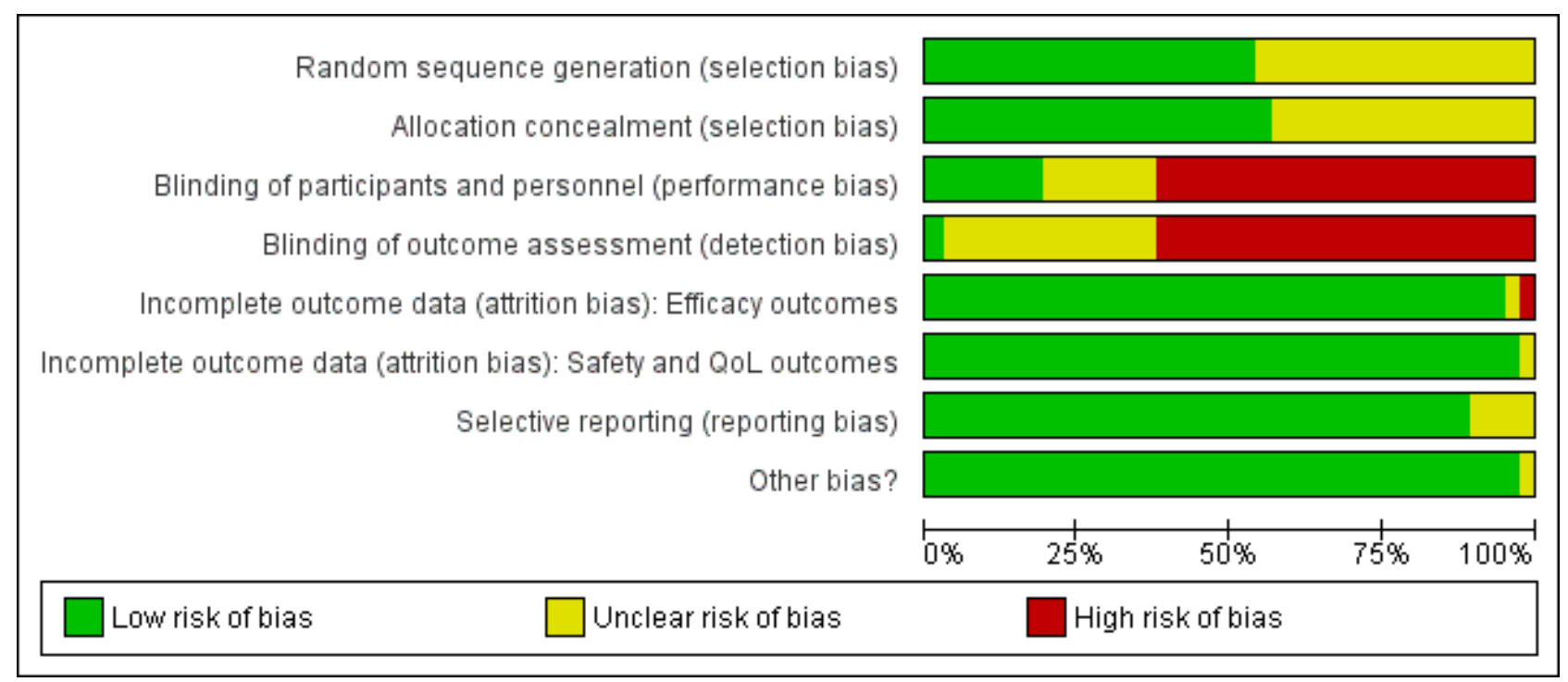


Figure 2.

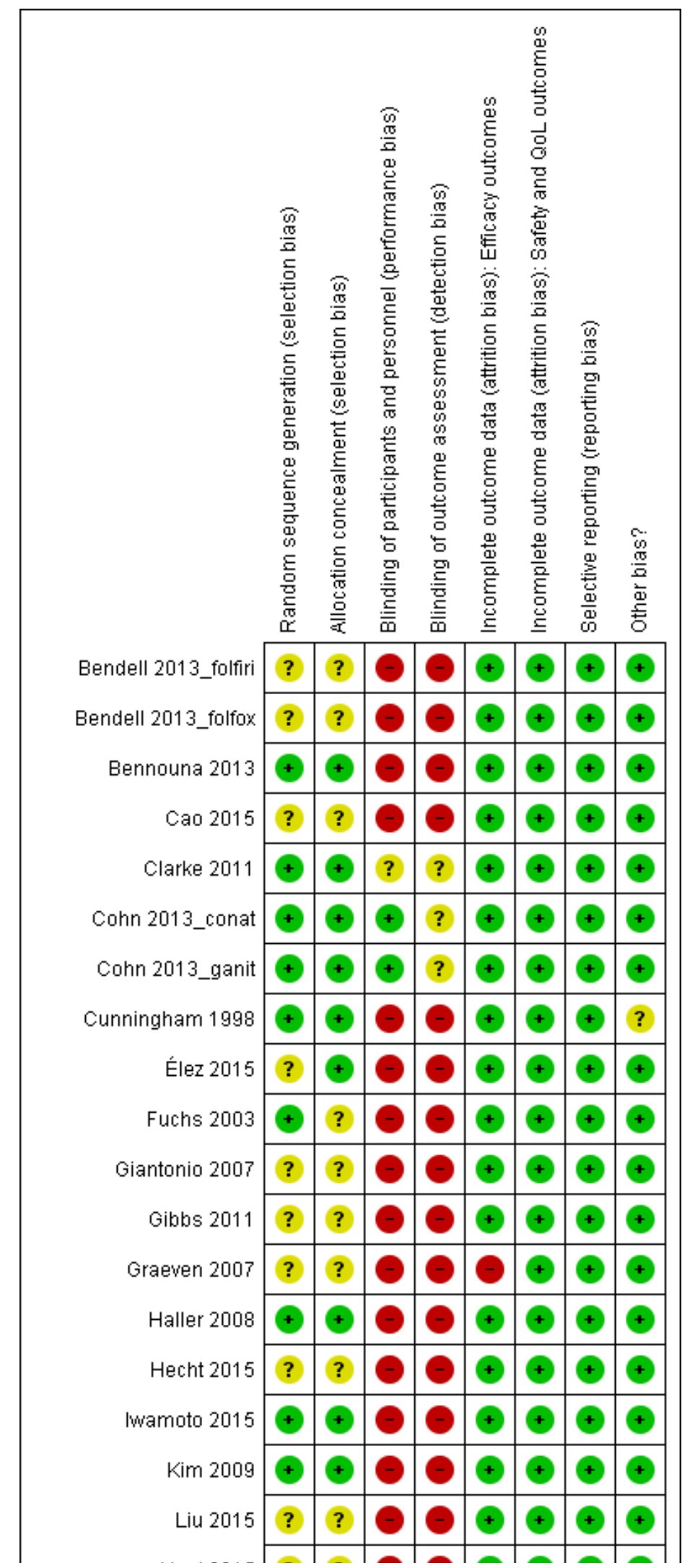


Figure 2. (Continued)

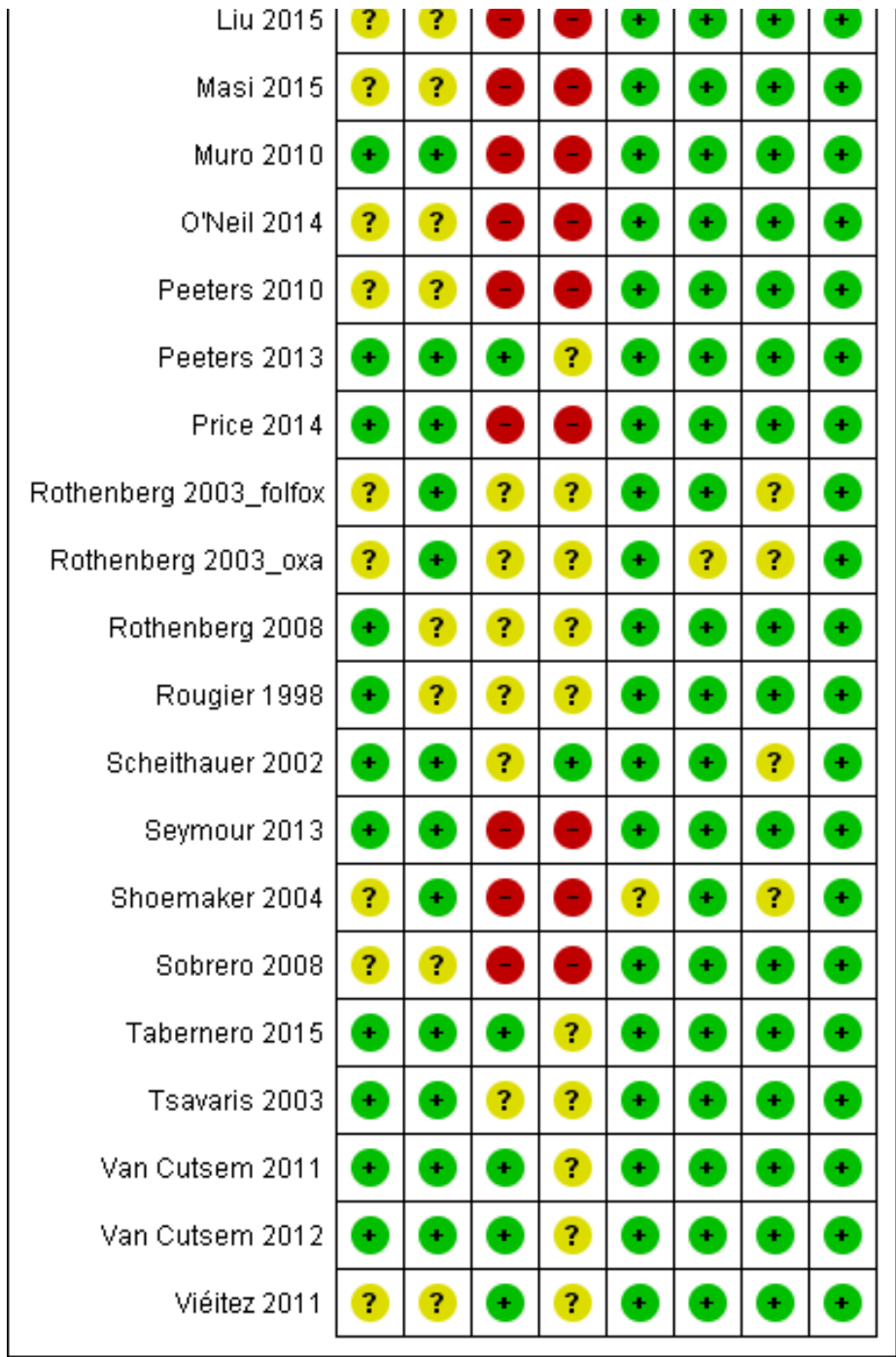

We resolved any disagreements by discussion or by involving a third author.

\section{Measures of treatment effect}

For each included trial, we measured treatment effects with HR for survival (time-to-event) data and risk ratio (RR) for dichotomous variables (i.e. ORR and SAE rate). We presented each effect estimate with its $95 \%$ confidence intervals (Cls) as a measure of uncertainty.

\section{Unit of analysis issues}

We did not encounter unit of analysis issues (we chose to exclude cluster-randomized trials and cross-over trials).

\section{Dealing with missing data}

The eligible articles did not report all outcomes of interest. We contacted the corresponding authors of these articles by email, but we could not retrieve the missing data either because the study had not been designed to collect those data or because we did not receive a reply. In case of dropouts, we considered the best-case and worse-case scenarios (for binary data only, as for time to event data this is unfeasible).

\section{Assessment of heterogeneity}

We assessed the consistency of results (effect sizes) across studies using the $1^{2}$ statistic (which indicates the percentage of the variability in effect estimates because of true betweenstudy variance rather than sampling error (within-study variance)). Heterogeneity was considered low, moderate or high for 12 values of less than $25 \%, 26 \%$ to $50 \%$ or greater than $50 \%$, respectively (Higgins 2003).

\section{Assessment of reporting biases}

Funnel plot is usually utilized to detect the so-called 'small-study effect' (Sterne 2000). Publication and selection biases in metaanalysis are more likely to affect small studies, which also tend to be of lower methodological quality: this may lead to a smaller study effect, where the smaller studies in a meta-analysis show larger treatment effects. Funnel plot asymmetry is formally investigated with the Egger linear regression approach: to be more conservative, usually this test is considered statistically significant when the $P$ value is less than 0.1 . However, since the test is poorly reliable (due to low power to detect bias, if present) when the number of trials is 
low (e.g. fewer than 10), we could not assess the small-study effect (all meta-analyses included fewer than 10 studies).

\section{Data synthesis}

When possible (at least two RCTs available), we pooled summary data for survival (OS, PFS) and dichotomous outcomes (ORR, SAE rate) obtained from relevant trials by means of meta-analysis using the random-effects model (inverse variance method). Since the estimation of between-study variance can be inaccurate when the number of trials is small, we adopted a fixed-effect model when fewer than four trials were available. Otherwise, we reported summary data (HRs, RRs along with their $95 \% \mathrm{Cl}$ ) of single RCTs.

For survival and toxicity data, a ratio lower than 1 favours the intervention, whereas for tumour response data a ratio greater than 1 favours the intervention.

Finally, we calculated the event rates in the control and experimental groups in order to provide readers with information on the absolute effect of treatment on participants' outcomes. In the light of the multiple comparisons we considered, we limited these calculations to the primary outcomes (OS and PFS), on which the main conclusions are based; since primary outcomes are based on survival data, the event rates were calculated as per Altman 1999.

\section{Subgroup analysis and investigation of heterogeneity}

We explored the potential sources of heterogeneity by means of subgroup analysis, which brings together RCTs more homogeneous by one or more features such as drug regimen (e.g. with or without targeted anticancer agents), study design (e.g. open label versus double blind), participants' characteristics (e.g. performance status, mean age) or disease characteristics (e.g. tumour stage). Testing the statistical difference between subgroups can be useful to identify regimens with better efficacy (or lower toxicity) or subsets of participants who benefit most from a given treatment. Unfortunately, the limited number of RCTs and the frequent lack of information on all these aspects did not allow us to perform all the planned subgroup analyses. Finally, sensitivity analysis was also carried out to investigate heterogeneity (see Sensitivity analysis).

Effect differences across subgroups were formally tested using the Cochrane Q-test for heterogeneity, as performed by the Review Manager 5 software (RevMan 2014).

\section{Sensitivity analysis}

We used a sensitivity analysis to assess the impact of specific trials (e.g. those with doubts about the randomization process or those characterized by a high risk of bias) by excluding them from the meta-analysis (if at least two RCTs were available). This can help test the robustness of meta-analysis findings, especially in the presence of result uncertainty (e.g. in the presence of substantial betweenstudy heterogeneity).

\section{Evidence grading}

We used the GRADE system to grade the quality of evidence (regarding primary outcome, that is, survival) into four levels (Guyatt 2011).

\begin{tabular}{ll}
\hline Grade & Definition \\
\hline High & Further research is very unlikely to change our confidence in the estimate of effect \\
\hline Moderate & $\begin{array}{l}\text { Further research is likely to have an impact on our confidence in the estimate of effect and may } \\
\text { change the estimate }\end{array}$ \\
\hline Low & $\begin{array}{l}\text { Further research is very likely to have an important impact on our confidence on the estimate of ef- } \\
\text { fect and is likely to change the estimate }\end{array}$ \\
\hline
\end{tabular}

Very low

Any estimate of effect is very uncertain

The quality of evidence can be downgraded by one (serious concern) or two (very serious concern) levels for the following reasons: risk of bias (see Assessment of risk of bias in included studies), inconsistency (unexplained heterogeneity, inconsistency of results), indirectness (indirect population, intervention, control, outcomes), imprecision (wide $\mathrm{Cls}$, single trial) and risk of publication bias. The quality can also be upgraded by one level due to large summary effect (we chose HR less than 0.6).

\section{RES U LTS}

\section{Description of studies}

\section{Results of the search}

We identified 1826 records through the electronic searches of the Cochrane Library (279 records), MEDLINE (332 records),
MEDLINE In-process \& Other Non-indexed citations (548 records) and Embase (667 records). We excluded 791 duplicates and 968 clearly irrelevant records through reading titles and abstracts. We retrieved the remaining 67 records for further assessment. Upon full-text reading, we excluded 41 studies for reasons listed in the Characteristics of excluded studies table. We identified eight additional studies through scanning reference lists of the identified RCTs.

In total, 34 RCTs fulfilled the inclusion criteria. The study flow diagram is shown in Figure 3. 
Figure 3. Study flow diagram.

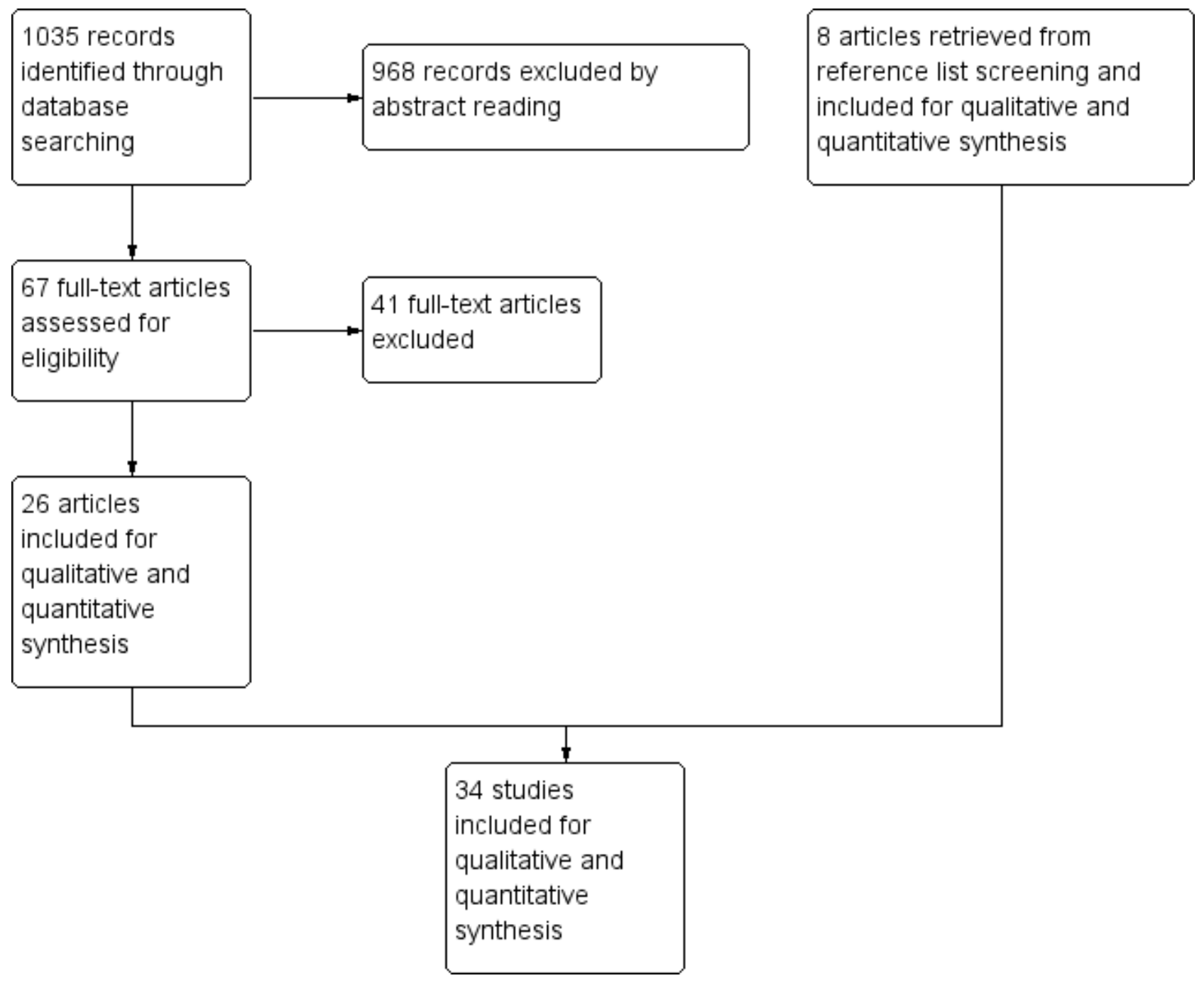

A list of abbreviations used in the text are reported in Table 1.

\section{Included studies}

The main features of each of the 34 included trials (overall enrolling 13,787 participants; range: 55 to 1298; median: 247) are reported in the Characteristics of included studies table. One trial compared four arms (Bendell 2013_folfiri), four trials compared three arms (Cohn 2013_conat; Élez 2015; O'Neil 2014; Rothenberg 2003_folfox), and the remaining 27 trials compared two arms. Only one trial compared a second-line chemotherapy regimen with best supportive care (Cunningham 1998). The other included studies compared two or more different second-line treatments.

All trials were comparable in terms of baseline characteristics (all participants enrolled had metastatic CRC and had not responded to a first-line treatment), except for the first-line regimens that could be different. As regards outcomes, OS, PFS, ORR and SAE data were reported in $31,31,30$ and 34 trials, respectively.

The drug regimens tested were heterogeneous. In particular, 17 different anticancer agents (alone or in combination) were tested: seven chemotherapy agents (5FU, oxaliplatin, irinotecan, mitomycin-C, raltitrexed, capecitabine, S-1) and 10 targeted agents (seven monoclonal antibodies: bevacizumab, cetuximab, panituzumab, abituzumab, conatumumab, ganitumab, ramucirumab; two small molecule inhibitors: vatalanib and gefitinib; and two recombinant blocking proteins: aflibercept and trebananib). The main features of these compounds are reported in Table 2. Two compounds (leucovorin and hyaluronan) utilized in some RCTs have no anticancer activity per se, but increase (leucovorin) or are supposed to increase (hyaluronan) the anticancer activity of chemotherapy agents.

The RCTs tested the following 25 drug combinations: 1 . FOLFOX (5FU plus leucovorin plus oxaliplatin), 2. FOLFIRI (5FU plus leucovorin plus irinotecan), 3. IRIS (S-1 plus irinotecan), 4. XELOX (capecitabine plus oxaliplatin), 5. bevacizumab plus FOLFIRI, 6. bevacizumab plus FOLFOX, 7. cetuximab plus irinotecan, 8 . panitumumab plus FOLFIRI, 9. panitumumab plus irinotecan, 10. panitumumab plus bevacizumab plus FOLFIRI, 11. axitinib plus FOLFOX, 12. axitinib plus FOLFIRI, 13. conatumumab plus FOLFIRI, 14. ganitumab plus FOLFIRI, 15. hyaluronan plus irinotecan, 16. oxaliplatin plus irinotecan, 17. linifanib plus FOLFOX, 18. ramucirumab plus FOLFIRI, 19. vatalanib plus FOLFOX, 20. 
aflibercept plus FOLFIRI, 21. gefitinib plus raltitrexed, 22. mitomycin plus oxaliplatin, 23. mitomycin plus irinotecan, 24) trebananib plus FOLFIRI and 25. abituzumab plus cetuximab plus irinotecan.

Only one trial used no anticancer treatment (best supportive care) as the control arm (the experimental arm was treatment with irinotecan) (Cunningham 1998).

\section{Excluded studies}

After reading the full text of 65 articles, we excluded 39 studies. Main reason for exclusion was that the trial did not focus on second-line therapy, rather the enrolment of people for first-line treatment or for third- or higher-line treatment.

Details regarding the reasons for exclusion of each study are reported in the Characteristics of excluded studies table.

\section{Risk of bias in included studies}

Figure 1 and Figure 2 show the risk of bias across trials and for each trial, respectively; details are reported in the 'Risk of bias' tables in the Characteristics of included studies table. Considering the risk of single biases across trials, a high risk was present in a significant proportion (greater than 50\%) of trials only for performance and detection bias (Figure 1). However, it should be noted that performance bias was unavoidable in some circumstances (e.g. chemotherapy compared to best supportive care); moreover, it is unlikely that this type of bias had a significant impact on the trial results and ultimately on the findings of the meta-analysis. While evaluating the risk of bias we did not find any difference between different outcomes; therefore, the risk assessment across domains is reported as a single assessment for all outcomes.

\section{Allocation}

There was no high risk of selection bias, although the risk was unclear for about $50 \%$ of the trials (Figure 1 ).

\section{Blinding}

There was high risk of bias in 22 open-label trials due to the lack of blinding (performance bias) intrinsic to the study design.

\section{Incomplete outcome data}

There was a high risk of attrition bias (incomplete outcome data) in only one study due to the following reasons: 1 . for survival outcome, neither the arm the two withdrawn participants belonged to, nor the reasons for withdrawal were reported; and 2. for tumour response, "39 patients were evaluable for response", therefore 16 participants were not evaluable (Graeven 2007).

\section{Selective reporting}

There was no high risk of reporting bias.

\section{Other potential sources of bias}

There was no high risk of other bias (e.g. baseline imbalances between arms).

\section{Effects of interventions}

See: Summary of findings for the main comparison Modern chemotherapy regimens compared with 5-flourouracil; Summary of findings 2 Chemotherapy + bevacizumab compared with

Second-line systemic therapy for metastatic colorectal cancer (Review) chemotherapy; Summary of findings 3 Irinotecan-based regimens compared with irinotecan; Summary of findings 4 Irinotecan + oxaliplatin compared with irinotecan; Summary of findings 5 Chemotherapy compared with best supportive care; Summary of findings 6 FOLFIRI + targeted therapy compared with FOLFIRI; Summary of findings 7 FOLFOX + targeted therapy compared with FOLFOX; Summary of findings $\mathbf{8}$ Irinotecan + targeted therapy compared with irinotecan

Table 3 shows a synopsis of the results (in terms of OS, PFS, ORR and SAEs) generated by each included trial.

The included RCTs rarely tested the same drugs or drug regimens. Therefore, the results of the 34 eligible trials could not be pooled. Nevertheless, the available evidence provided us with the opportunity to group (and meta-analyze) RCTs addressing the same clinical issue (e.g. does the addition of targeted agents improve the efficacy of conventional chemotherapy?), although - singularly taken - they tested drug regimens that were not always identical (e.g. different targeted agents or different chemotherapy drugs).

Due to space considerations and in order to ease the interpretation of the wealth of data reported in this review, we reported forest plots and 'Summary of findings' tables only for the primary outcome (survival) in case of clinical practice changing results (i.e. for the comparisons on which the main conclusions of this review are based).

Nine out of 34 studies (26\%) formally addressed QoL with participant compliance being 50\% to 60\% (Clarke 2011; Cunningham 1998; Fuchs 2003; Peeters 2010; Price 2014; Rougier 1998; Seymour 2013; Sobrero 2008; Tabernero 2015). Although most investigators used similar questionnaires, the (few) data could not be meta-analyzed since no article reported the actual scores (neither individual nor summary data). As regards single studies, six trials reported no significant differences in QoL (Clarke 2011; Fuchs 2003; Peeters 2010; Price 2014; Rougier 1998; Tabernero 2015). QoL was better in participants treated with irinotecan compared to those treated with best supportive care (Cunningham 1998), irinotecan plus panitumumab versus irinotecan alone (Seymour 2013), and cetuximab plus irinotecan versus irinotecan alone (Sobrero 2008).

The available evidence enabled us to address the following clinical issues.

\section{Modern chemotherapy regimens versus 5-fluorouracil}

Two RCTs (726 participants) compared 5FU (the first chemotherapeutic agent to be associated with survival advantage in first-line treatment of people with metastatic (RC) with three different chemotherapy regimens (including more modern drugs): FOLFOX (Rothenberg 2003_folfox), oxaliplatin (Rothenberg 2003_oxa), and irinotecan (Rougier 1998).

Only one trial (167 participants) addressed OS and showed a significant advantage for participants treated with irinotecan (HR $0.69,95 \% \mathrm{Cl} 0.51$ to 0.94 ) (Rougier 1998). Both trials reported PFS: considering the single comparisons, both FOLFOX and irinotecan were better than $5 \mathrm{FU}$, whereas oxaliplatin was not. By pooling the PFS data of the three comparisons, regimens other than 5FU alone performed better than 5FU alone (HR 0.84, 95\% Cl 0.73 to 0.96 ) (Figure 4), a finding characterized by a high betweenstudy heterogeneity $\left(1^{2}=91 \%\right)$ sustained by the poor activity of 
oxaliplatin alone. The 'leave-one-out' sensitivity analysis showed that heterogeneity reduced to $11 \%$ if the oxaliplatin versus $5 \mathrm{FU}$ comparison was excluded; in this case, FOLFOX and irinotecan showed a clinically relevant and statistically significant PFS advantage compared to 5FU in second-line therapy of metastatic CRC (HR 0.59, 95\% Cl 0.49 to 0.73). Based on the GRADE system, we rated this evidence as high (no reason for downgrading) (Summary of findings for the main comparison).

\section{Figure 4.}

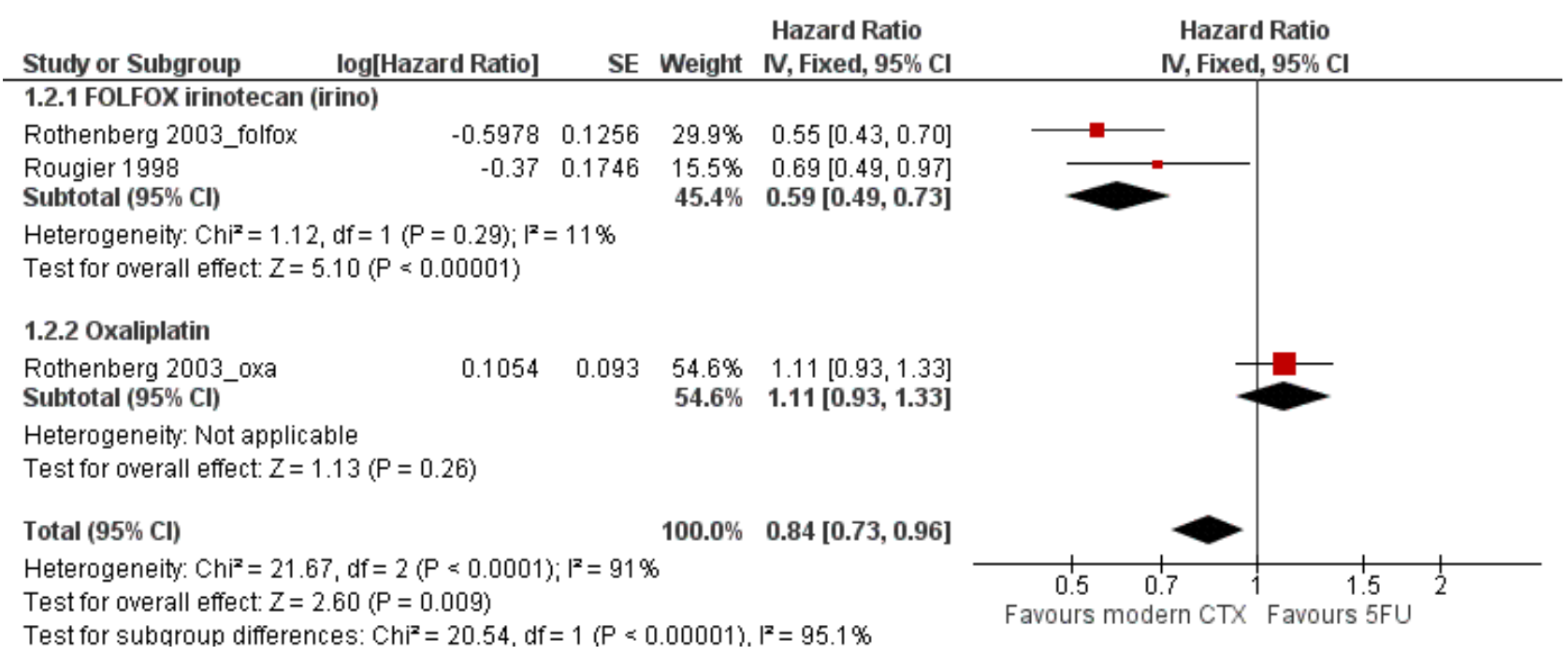

For tumour response data, at meta-analysis, ORR was significantly higher for other chemotherapy regimens compared to 5FU (RR 2.96, $95 \% \mathrm{Cl} 1.66$ to 5.27), although this finding was not supported by the oxaliplatin versus $5 \mathrm{FU}$ comparison. Finally, the SAE rate was higher in participants treated with modern chemotherapy regimens (RR $1.39,95 \% \mathrm{Cl} 1.22$ to 1.58$)$.

\section{Irinotecan plus other anticancer agents versus irinotecan}

Six trials assessed the effect of adding other anticancer agents (5FU, oxaliplatin, hyaluronan acid (a drug carrier), panitumumab, cetuximab) to irinotecan (2615 participants) (Clarke 2011; Gibbs 2011; Graeven 2007; Haller 2008; Seymour 2013; Sobrero 2008).

Only one trial (627 participants) found a statistically significant advantage for both OS (HR $0.78,95 \% \mathrm{Cl} 0.67$ to 0.90$)$ and PFS (HR
$0.60,95 \% \mathrm{Cl} 0.55$ to 0.66 ), when irinotecan was combined with oxaliplatin (also known as IROX regimen) (Haller 2008). The grade of evidence was moderate (because there was only one study) (Summary of findings 4).

When the results of the six studies were pooled together, there was no OS advantage (HR $0.91,95 \% \mathrm{Cl} 0.79$ to 1.04 ), with a nonnegligible between-study heterogeneity $(12=42 \%)$. In contrast, there was both a PFS advantage ( $\mathrm{HR} 0.68,95 \% \mathrm{Cl} 0.60$ to 0.76 ) (Figure 5) and an ORR advantage (RR $2.87,95 \% \mathrm{Cl} 2.10$ to 3.93 ) for combination regimens, with no significant difference in terms of toxicity (RR $1.18,95 \% \mathrm{Cl} 0.96$ to 1.45 ); the grade of evidence was moderate (since the PFS findings were not confirmed by the OS data) (Summary of findings 3 ).

\section{Figure 5.}

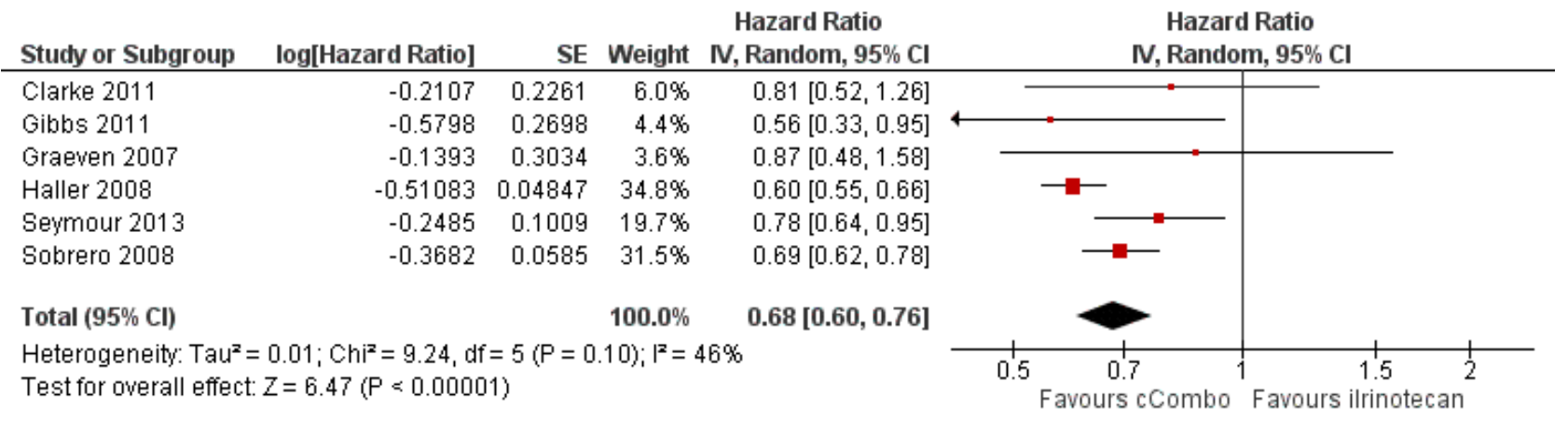

Since the between-study heterogeneity was moderate to high for all outcomes, we searched for more homogeneous results by subgroup analysis. Pooling the data of two trials (144 participants) comparing the same regimens (irinotecan versus FOLFIRI) found no OS, PFS, ORR or SAE differences (Clarke 2011; Graeven 2007). 
Heterogeneity was drastically reduced (I2 less than $25 \%$ ) when we meta-analyzed the data of the two trials (1758 participants) testing the hypothesis that the addition of targeted agents (panitumumab, cetuximab) might enhance the therapeutic efficacy of irinotecan (Seymour 2013; Sobrero 2008): both PFS (HR 0.71, 95\% Cl 0.64 to 0.79 ) and ORR (RR $3.38,95 \% \mathrm{Cl} 2.52$ to 4.53 ) were significantly better in the combination regimen; however, there was no significant OS difference (HR 0.99, $95 \% \mathrm{Cl} 0.88$ to 1.10 ), and the rate of SAEs was significantly higher with the combination regimen (RR $1.44,95 \% \mathrm{Cl}$ 1.31 to 1.59); the grade of evidence was moderate because the PFS findings were not confirmed by the OS data (Summary of findings 8).

\section{Fractionated irinotecan versus single-dose irinotecan}

Three RCTs compared irinotecan administered as single dose (every three weeks) with that of irinotecan fractionated (with different schedules) (Fuchs 2003, 391 participants; Shoemaker 2004, 85 participants; Tsavaris 2003, 120 participants). There were no statistically significant differences in terms of OS (HR 0.86, 95\% Cl 0.71 to 1.05; 2 RCTs) (Fuchs 2003; Tsavaris 2003), PFS (HR 0.90,
95\% Cl 0.71 to 1.14; 2 RCTs) (Fuchs 2003; Tsavaris 2003), ORR (RR $0.83,95 \% \mathrm{Cl} 0.45$ to $1.53 ; 2$ RCTs) (Shoemaker 2004; Tsavaris 2003), and SAE (RR 0.97, 95\% Cl 0.87 to 1.10; 3 RCTs) (Fuchs 2003; Shoemaker 2004; Tsavaris 2003).

\section{Bevacizumab plus chemotherapy versus chemotherapy}

Four RCTs (1723 participants) addressed the addition of bevacizumab to chemotherapy (oxaliplatin- or irinotecan-based regimens) (Bennouna 2013; Cao 2015; Giantonio 2007; Masi 2015).

All four studies demonstrated a survival advantage for the combination arms, although this advantage was only statistically significant in two RCTs (Bennouna 2013; Giantonio 2007). Pooling the OS data from all four studies showed that bevacizumab can lead to a survival advantage ( $\mathrm{HR} 0.79,95 \% \mathrm{Cl} 0.70$ to 0.88 ) (Figure $6)$, with no between-study heterogeneity $\left(I^{2}=0 \%\right)$. The four single trials reported even better results for PFS, which was confirmed by meta-analysis (HR $0.67,95 \% \mathrm{Cl} 0.60$ to 0.75 ) (Figure 7). Based on the GRADE system, we rated the evidence as high (no reason for downgrading) (Summary of findings 2).

Figure 6.

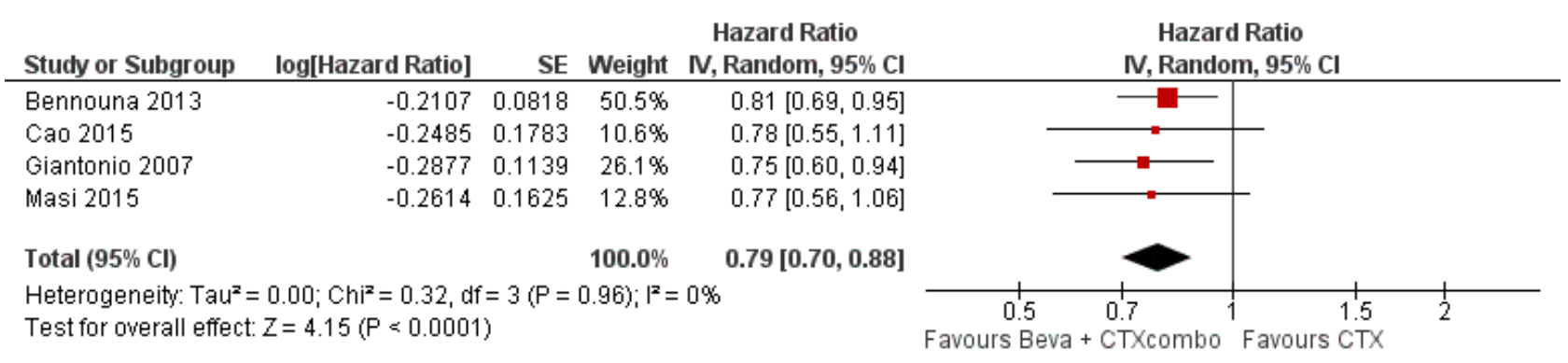

Figure 7.

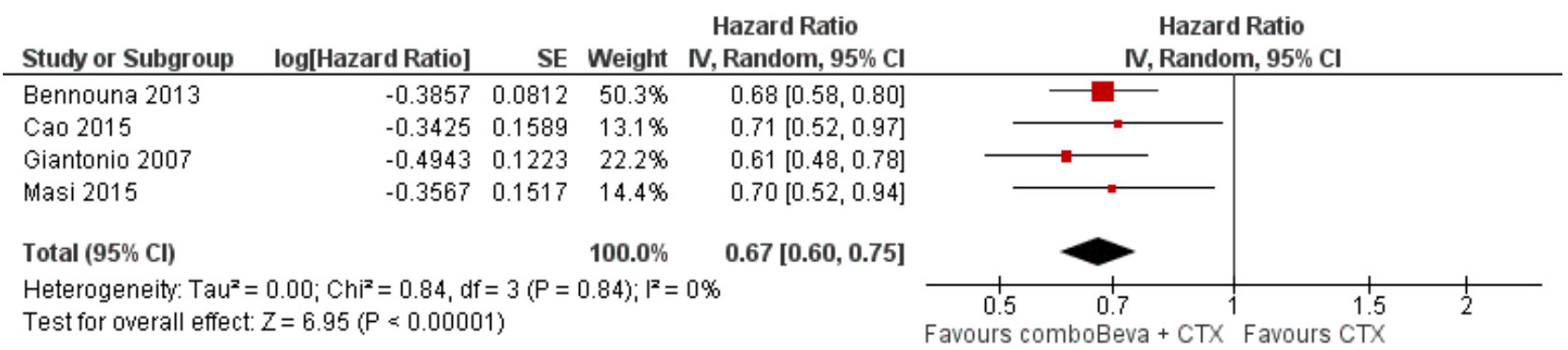

ORR data were in line with survival data as the response rates were higher in the bevacizumab-containing regimens (RR $1.72,95 \% \mathrm{Cl}$ 1.23 to 2.43). Interestingly, the addition of bevacizumab did not significantly increase the risk of SAEs (RR 1.07, 95\% Cl 0.93 to 1.25).

\section{FOLFIRI plus targeted agents versus FOLFIRI}

Six trials (3335 participants) tested the hypothesis that adding other anticancer agents to the FOLFIRI regimen (conventional chemotherapy drugs only) might increase therapeutic efficacy investigating seven different targeted drugs: conatumumab
(Cohn 2013_conat), ganitumab (Cohn 2013_ganit), panitumumab (Peeters 2010), bevacizumab (plus panitumumab) (Liu 2015), trebananib (Peeters 2013), ramucirumab (Tabernero 2015), and aflibercept (Van Cutsem 2012). Singularly taken, only three RCTs showed a significant improvement in OS (Liu 2015; Tabernero 2015; Van Cutsem 2012); pooling the data of all six trials, we found that the addition of targeted agents did increase life expectation (HR $0.84,95 \% \mathrm{Cl} 0.77$ to 0.91 ) (Figure 8 ). There were similar results when pooling PFS data (HR $0.78,95 \% \mathrm{Cl} 0.71$ to 0.87 ) (Figure 9) and ORR data (RR 2.07, $95 \% \mathrm{Cl} 1.31$ to 3.28 ). 
Figure 8.

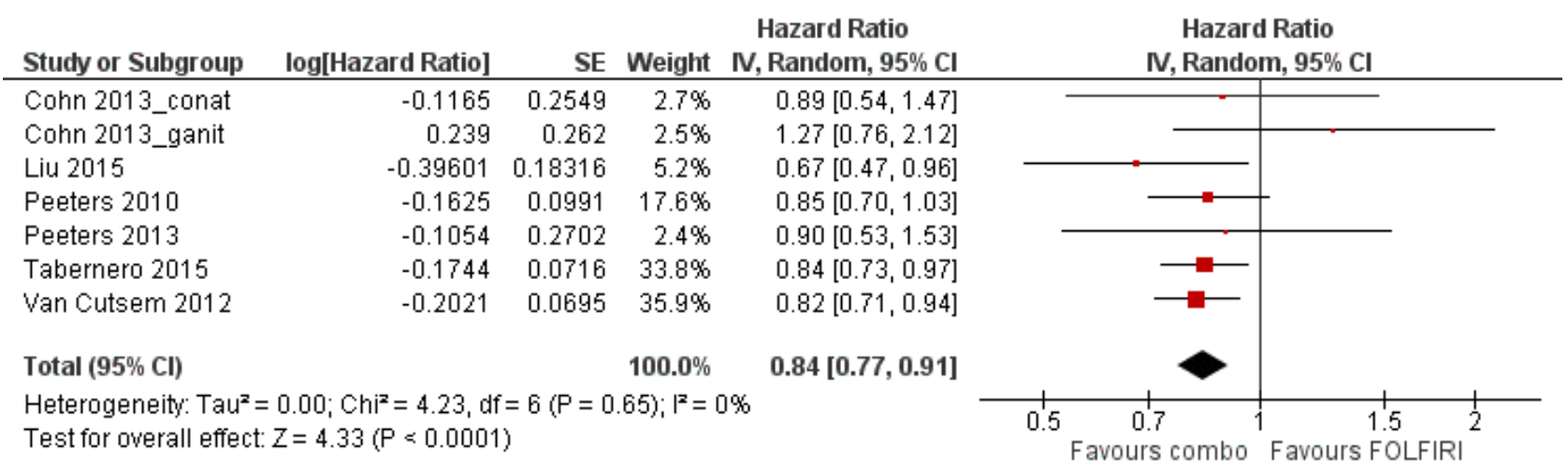

Figure 9.

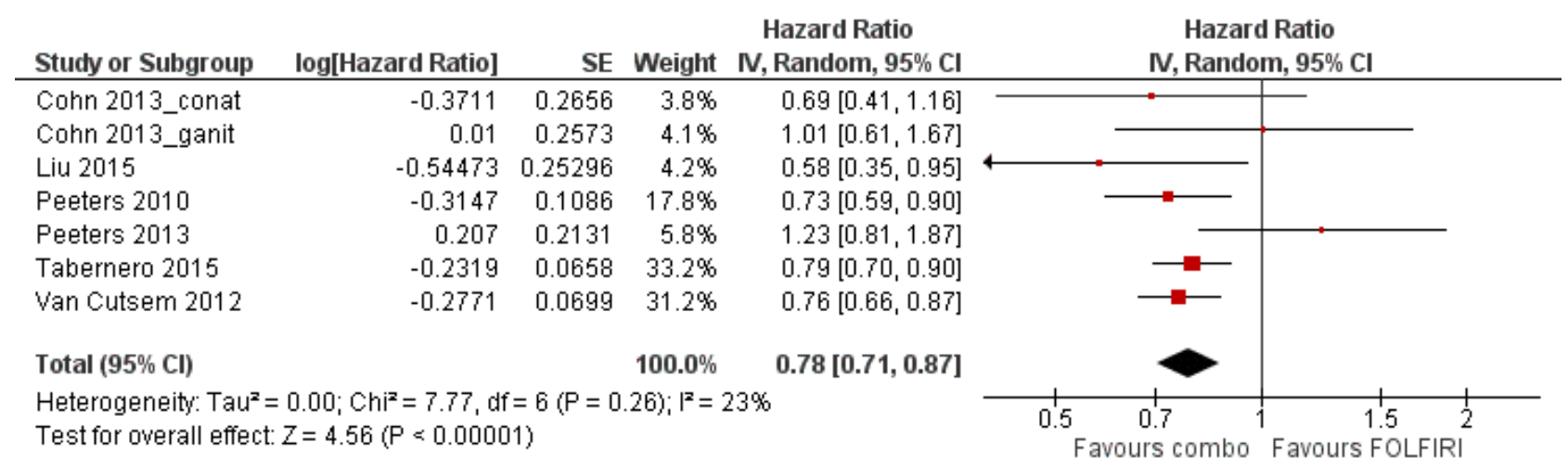

Importantly, the addition of targeted agents also significantly increased the incidence of SAES (RR $1.30,95 \% \mathrm{Cl} 1.17$ to 1.45 ). At subgroup analysis, considering the three trials (2440 participants) that investigated targeted agents blocking exclusively the VEGF pathway (bevacizumab, ramucirumab, aflibercept), findings were even more homogeneous in terms of survival (OS: HR $0.82,95 \% \mathrm{Cl}$ 0.74 to 0.90 ; PFS: HR $0.77,95 \% \mathrm{Cl} 0.70$ to 0.84 ).

Based on the GRADE system, we rated the evidence as high.

\section{FOLFOX plus targeted agents versus FOLFOX}

Two RCTs (1432 participants) tested the hypothesis that adding targeted agents (bevacizumab and vatalanib) to the FOLFOX regimen (chemotherapy drugs only) might increase therapeutic efficacy (bevacizumab: Giantonio 2007; vatalanib: Van Cutsem 2011). The meta-analysis of the two trials showed a significantly improved PFS when targeted agents were added to FOLFOX (HR $0.76,95 \% \mathrm{Cl} 0.66$ to 0.86 ) (Figure 10), although there was a high degree of heterogeneity $\left(\mathrm{I}^{2}=78 \%\right)$. Addition of targeted agents also improved OS, although this result did not reach statistical significance (HR $0.92,95 \% \mathrm{Cl} 0.82$ to 1.04 ).

Figure 10.

\begin{tabular}{|c|c|c|c|c|c|c|}
\hline Study or Subgroup & log[Hazard Ratio] & SE & Weight & $\begin{array}{c}\text { Hazard Ratio } \\
\text { IV, Fixed, } 95 \% \text { CI }\end{array}$ & \multicolumn{2}{|c|}{$\begin{array}{c}\text { Hazard Ratio } \\
\text { IV, Fixed, } 95 \% \mathrm{Cl}\end{array}$} \\
\hline Giantonio 2007 & -0.4943 & 0.1223 & $29.8 \%$ & $0.61[0.48,0.78]$ & $\longrightarrow$ & \\
\hline Van Cutsem 2011 & -0.1863 & 0.0797 & $70.2 \%$ & $0.83[0.71,0.97]$ & & \\
\hline Total $(95 \% \mathrm{Cl})$ & & & $100.0 \%$ & $0.76[0.66,0.86]$ & & \\
\hline $\begin{array}{l}\text { Heterogeneity: } \mathrm{Chi}^{2} \\
\text { Test for overall effec }\end{array}$ & $\begin{array}{l}4.45, d f=1(P=0.0 \\
Z=4.17(P \leq 0.0001\end{array}$ & ); $1^{2}=78$ & & & $\begin{array}{ll}1 & 1 \\
0.5 & 0.7 \\
\text { Favours combo }\end{array}$ & $\begin{array}{cc}1.5 & 1 \\
\text { Favours FOLFOX }\end{array}$ \\
\hline
\end{tabular}

Finally, the incidence of SAEs was significantly higher among participants receiving the combination regimen (RR 1.2, 95\% Cl 1.13 to 1.28$)$. Only one study reported ORR, which showed an advantage for the regimen including bevacizumab (Giantonio 2007). 
Based on the GRADE system, we rated the evidence as low (due to high heterogeneity and PFS data not confirmed by OS data).

\section{FOLFIRI plus bevacizumab versus FOLFIRI plus other targeted agents}

Two trials (282 participants) compared the FOLFIRI chemotherapy regimen in combination with either bevacizumab or other targeted agents (axitinib or panitumumab) (Bendell 2013_folfiri; Hecht 2015). Neither study reported a significant OS difference between the two approaches, a result confirmed by data meta-analysis (HR $1.15,95 \% \mathrm{Cl} 0.86$ to 1.53 ). There were similar findings for PFS and ORR both in single studies and meta-analysis (PFS: HR 1.10, 95\% Cl 0.81 to 1.50 ; ORR: $\mathrm{RR} 1.44,95 \% \mathrm{Cl} 0.94$ to 2.20 ).

Toxicity findings favoured the bevacizumab-containing regimen (other agents versus bevacizumab comparison: RR 1.53, 95\% $\mathrm{Cl} 1.10$ to 2.11). Due to the low number of participants randomized, any result should be interpreted with caution (due to low statistical power considerations).

Using the GRADE system, we rated the evidence as low (due to imprecision and low statistical power).

\section{FOLFOX plus bevacizumab versus FOLFOX plus other targeted agents}

Two trials (169 participants) compared the FOLFOX chemotherapy regimen in combination with either bevacizumab or other targeted agents (Axitinib or Linifanib) (Bendell 2013_folfox; O'Neil 2014). Neither study reported a significant OS difference between the two approaches, a result confirmed by data meta-analysis (HR 1.14, $95 \% \mathrm{Cl} 0.81$ to 1.61). There were similar findings for PFS and ORR both in single studies and meta-analysis (PFS: HR 1.26, 95\% Cl 0.83 to 1.91 ; ORR: RR $0.77,95 \% \mathrm{Cl} 0.46$ to 1.29 ).

Toxicity findings favoured the bevacizumab-containing regimen (other agents versus bevacizumab comparison: RR 1.27, 95\% Cl 1.03 to 1.55$)$. Due to the low number of participants randomized, any result should be interpreted with caution (due to low statistical power considerations).

Using the GRADE system, we rated the evidence as low (due to imprecision and low statistical power).

\section{Other comparisons based on single trials}

Single RCTs compared the following regimens (for details see Characteristics of included studies and Table 3).

\section{Irinotecan versus best supportive care}

This trial (279 participants) is particularly important because it showed that anticancer therapy (irinotecan) provided a significant OS advantage ( $\mathrm{HR} 0.58,95 \% \mathrm{Cl} 0.43$ to 0.80 ) even in second-line (all enrolled participants were refractory to first-line 5FU) compared to best supportive care, although at the cost of a (predictable) higher incidence of SAEs (RR 1.19, 95\% Cl 1.01 to 1.40) (Cunningham 1998).

Using the GRADE system, we rated the evidence as moderate (since there was only one trial).

\section{IRIS versus FOLFIRI}

This trial (426 participants), which compared IRIS versus FOLFIRI (both contained irinotecan), found that the two regimens were very similar in terms of survival, tumour response and toxicity outcomes (Muro 2010).

Using the GRADE system, we rated the evidence as low (due to imprecision and low statistical power).

\section{XELOX versUS FOLFOX}

This study (627 participants), in which the two combination regimens basically differed by using oral (XELOX: capecitabine) instead of intravenous (FOLFOX: 5FU) fluoropyrimidine, suggested that the survival and tumour response results achieved with XELOX were similar to those with FOLFOX, but with the advantage of a lower incidence of SAEs (RR 0.75, 95\% Cl 0.68 to 0.82) (Rothenberg 2008).

Using the GRADE system, we rated the evidence as moderate (since there was only one trial).

\section{FOLFOX versus irinotecan}

This RCT (491 participants), which compared FOLFOX with singleagent irinotecan, found no significant difference in OS; however, participants who received FOLFOX showed better PFS and ORR, which were not associated with a significant increase in toxicity (Kim 2009).

Using the GRADE system, we rated the evidence as low (due to imprecision and low statistical power).

\section{Mitomycin plus oxaliplatin versus mitomycin plus irinotecan}

The investigators of this trial (64 participants) did not report survival outcomes. There were no statistically significant differences between the two chemotherapy regimens in tumour response and toxicity (Scheithauer 2002).

Using the GRADE system, we rated the evidence as very low (due to imprecision and very low statistical power).

\section{Gefitinib plus raltitrexed versus raltitrexed}

The addition of targeted agent gefitinib to chemotherapy agent raltitrexed did not improve OS, PFS or ORR (76 participants). There were no toxicity differences reported between the two study arms (Viéitez 2011).

Using the GRADE system, we rated the evidence as very low (due to imprecision and very low statistical power).

\section{Different bevacizumab dosages}

One trial (369 participants) compared two bevacizumab dosages (used in association with FOLFIRI) (Iwamoto 2015). Since there were no statistically significant differences in terms of OS, PFS, ORR or SAEs, the authors concluded that higher-dose bevacizumab did not perform better than lower-dose bevacizumab when associated with FOLFIRI.

Using the GRADE system, we rated the evidence as low (due to imprecision and low statistical power).

\section{Panitumumab versus cetuximab}

In this trial (999 participants), the investigators did not detect significant differences between the two targeted agents 
panitumumab and cetuximab in terms of OS, PFS, ORR or SAES (Price 2014).

Using the GRADE system, we rated the evidence as moderate (since there was only one trial available).

\section{Abituzumab plus cetuximab plus irinotecan versus cetuximab plus irinotecan}

The results of this RCT (216 participants) suggested that targeted agent abituzumab (both low and high dose) does not add any advantage (in terms of OS, PFS, ORR or SAEs) to the cetuximab plus irinotecan combination (Élez 2015).

Using the GRADE system, we rated the evidence as low (due to imprecision and low statistical power).

\section{DISCUSSION}

This is the first systematic review and meta-analysis addressing the issue of the performance (efficacy plus toxicity) of second-line systemic therapy in people with metastatic (TNM stage IV) CRC. Our findings are based on the data collected from 34 eligible RCTs enrolling 13,787 participants.

Since the included RCTs tested a variety of drug regimens, it was almost always impossible to pool results from identical comparisons. Nevertheless, we exploited the available evidence in order to answer clinically relevant broad questions, which implied the meta-analysis of RCTs addressing the same issue (e.g. do targeted drugs increase the efficacy of chemotherapy?) though singularly taken - they tested different drug regimens (e.g. different targeted agents).

\section{Summary of main results}

The main findings of our work can be summarized as the answers to the following clinical questions.

- Is second-line chemotherapy effective in people with metastatic CRC?

Only one RCT addressed this issue. It demonstrated a significant survival advantage for people undergoing chemotherapy (irinotecan) compared to people treated with best supportive care. Obviously, chemotherapy was accompanied by a higher rate of toxicity. The level of evidence was moderate because this result was based on a single study.

- Are modern chemotherapy regimens superior to outdated $5 \mathrm{FU}$ ?

The results of two RCTs showed that modern chemotherapy regimens (FOLFOX and irinotecan) were more effective than 5FU alone, although at the cost of a higher toxicity rate. The level of evidence was high.

\section{- Are irinotecan-based regimens better than irinotecan alone?}

In general, irinotecan-based regimens were better than irinotecan alone, although results were heterogeneous, which was probably linked to the variety of treatments included. When we looked at more homogeneous subgroups, two combinations were significantly associated with a better efficacy: irinotecan plus targeted agents (two RCTs testing anti-EGFR agents cetuximab and panitumumab; grade of evidence: moderate, since the PFS finding was not supported by the OS finding) and irinotecan plus oxaliplatin (IROX regimen; one RCT; grade of evidence: moderate, as there was only one RCT). In both cases, improved efficacy was accompanied by a higher rate of SAEs. Of note, the combination regimen, FOLFIRI, was not superior to irinotecan alone.

- Does targeted agent bevacizumab increase the efficacy of chemotherapy?

Four RCTs addressed this issue and found that bevacizumab significantly increased the efficacy of chemotherapy (miscellany of regimens); interestingly, this benefit was not paralleled by a significant increase in toxicity rates. The grade of evidence was high.

- Do targeted agents increase the efficacy of FOLFIRI or FOLFOX?

The evidence from eight RCTs (FOLFIRI, 6 RCTs; FOLFOX, 2 RCTs) supported the superiority of combination regimens including targeted agents; however, the grade of evidence was high for FOLFIRI and low for FOLFOX (due to results heterogeneity and PFS data not confirmed by OS data). In both cases, improved efficacy was accompanied by a higher rate of SAEs.

Importantly, we would like to underscore that the answers to the last two questions strongly support the use of targeted agents in combination with chemotherapy for the treatment of people with metastatic CRC who did not respond to first-line treatment. Interestingly, the use of bevacizumab was associated with higher efficacy without increased toxicity, a common finding when dealing with regimens that show better anticancer activity (see the comparisons 'Modern chemotherapy regimens versus 5-fluorouracil', 'Irinotecan plus other anticancer agents versus irinotecan', and 'Irinotecan and best supportive care'). In particular, other widely used targeted agents, such as those targeting the EGFR pathway (e.g. cetuximab and panitumumab) which improve people's survival (when added to chemotherapy), are accompanied by a significantly worse tolerability (see comparison 'Irinotecan plus other anticancer agents versus irinotecan').

Regarding secondary endpoints, both response and toxicity rates are usually directly proportional to efficacy (i.e. the higher the efficacy, the higher the rates of both tumour shrinkage and SAEs); this was the case for the regimens compared with the exception of bevacizumab (which appeared to lead to higher response rates when combined with chemotherapy, without increasing toxicity). Another important clue comes from the comparison between oral and intravenous fluoropyrimidines (combined with oxaliplatin), which supports the use of oral administration due to similar efficacy, lower toxicity rates and easier route of administration (Rothenberg 2008).

\section{Overall completeness and applicability of evidence}

Although the above findings provide clinicians with some useful information, some unanswered questions remain. For instance, many comparisons showing no statistically significant difference between regimens were based on single trials enrolling a number of participants insufficient to obtain a satisfactory statistical power, which prevents us from drawing any definitive conclusions based on those results. Moreover, not all comparisons were available, which did not enable us to generate a full ranking of the variety of tested regimens. For example, thus far no RCT has investigated irinotecan plus bevacizumab (versus irinotecan alone), which 
would be a potentially useful combination of two drugs with established efficacy when individually taken as second-line therapy for people with metastatic CRC.

Since they are based on moderate to high quality evidence, the main findings of this review could be helpful to guide clinicians for the routine clinical practice in the choice of second-line therapy for people with metastatic CRC.

\section{Quality of the evidence}

The main conclusions of this review (see Summary of main results) are based on moderate to high-quality evidence; the main reason for downgrading being inconsistency due to the fact that PFS findings were not confirmed by OS data. Nevertheless, it should be remembered that PFS is nowadays considered a reliable surrogate of OS (which includes disease-unrelated events and requires longer follow-ups) in the setting of second-line therapy for metastatic CRC (Buyse 2007; Giessen 2015).

\section{Potential biases in the review process}

Although always possible, we believe it is unlikely that a significant bias was introduced in the search for trials. Moreover, we employed the high-quality Cochrane methods to evaluate trials and conducting data analysis.

\section{Agreements and disagreements with other studies or reviews}

Only one systematic review has so far been published on this subject (Giessen 2015); this work had the specific aim to investigate PFS and ORR as potential surrogate endpoints for OS and found 23 RCTs (our review identified 34 studies). Moreover, only one systematic review and meta-analysis has been published in this field (Beretta 2013), but its area of interest was limited to one treatment (FOLFIRI plus bevacizumab); the results of this work (based on both randomized and non-randomized trials) were in line with the findings of this review.

\section{AUTHORS' CONCLUSIONS}

\section{Implications for practice}

Systemic therapy offers a survival benefit to people with metastatic colorectal cancer (CRC) who did not respond to first-line treatment, especially when targeted agents are combined with conventional chemotherapeutic drugs. This review provides clinicians with several clues on the choice of second-line therapy for people with metastatic CRC who have not responded to first-line treatment, such as the superiority of some chemotherapy regimens and the advantage of adding targeted agents to chemotherapy.

\section{Implications for research}

Our findings highlight the need for further research in order to address some issues, such as:

- the evidence on some treatments was based on single trials, which precludes any definitive conclusion on those regimens;

- considering the positive results yielded with targeted agents, then other compounds should be tested in this setting that are being successfully used against other tumour types (e.g. coinhibitory molecule inhibitors);

- novel biomarkers predictive of tumour response are needed (besides KRAS mutational status for epidermal growth factor receptor (EGFR) pathway inhibitors) in order to improve our ability to select people with the highest likelihood of benefiting from a given therapy (personalized cancer medicine);

- data on the quality of life of people with cancer should become a mandatory item while designing and running a cancer trial in order to formally investigate the balance between survival benefits provided by second-line systemic therapy and treatment-related toxicity.

\section{ACKNOWLEDGEMENTS}

We truly thank Dr Marta Briarava (data manager of the MetaAnalysis Unit of the University of Padova, Padova, Italy) for her invaluable help with the setup and management of the dedicated database we used for the collection and analysis of the literature data.

We would also like to thank Juan-José López and the previous authors for their contribution to the first published version of this review. 


\section{R E F E R E N C E S}

\section{References to studies included in this review}

Bendell 2013_folfiri \{published data only\}

Bendell JC, Tournigand C, Swieboda-Sadlej A, Barone C, Wainberg ZA, Kim JG, et al. Axitinib or bevacizumab plus FOLFIRI or modified FOLFOX- 6 after failure of first-line therapy for metastatic colorectal cancer: a randomized phase II study. Clinical Colorectal Cancer 2013;12:239-47.

\section{Bendell 2013_folfox \{published data only\}}

Bendell JC, Tournigand C, Swieboda-Sadlej A, Barone C, Wainberg ZA, Kim JG, et al. Axitinib or bevacizumab plus FOLFIRI or modified FOLFOX-6 after failure of first-line therapy for metastatic colorectal cancer: a randomized phase II study. Clinical Colorectal Cancer 2013;12:239-47.

\section{Bennouna 2013 \{published data only\}}

Bennouna J, Sastre J, Arnold D, Österlund P, Greil R, Van Cutsem E, et al. Continuation of bevacizumab after first progression in metastatic colorectal cancer (ML18147): a randomised phase 3 trial. Lancet Oncology 2013;14:29-37.

\section{Cao 2015 \{published data only\}}

Cao R, Zhang S, Ma D, Hu L. A multicenter randomized phase Il clinical study of bevacizumab plus irinotecan, 5-fluorouracil, and leucovorin (FOLFIRI) compared with FOLFIRI alone as second-line treatment for Chinese patients with metastatic colorectal cancer. Medical Oncology 2015;32:325.

\section{Clarke 2011 \{published data only\}}

Clarke SJ, Yip S, Brown C, van Hazel GA, Ransom DT, Goldstein D, et al on behalf of the Australasian Gastro-Intestinal Trials Group. Single-agent irinotecan or 5-fluorouracil and leucovorin (FOLFIRI) as second-line chemotherapy for advanced colorectal cancer; results of a randomised phase II study (DaVINCI) and meta-analysis. European Journal of Cancer 2011;47(12):1826-36.

\section{Cohn 2013_conat \{published data only\}}

Cohn AL, Tabernero J, Maurel J, Nowara E, Sastre J, Chuah BY, et al. A randomized, placebo-controlled phase 2 study of ganitumab or conatumumab in combination with FOLFIRI for second-line treatment of mutant KRAS metastatic colorectal cancer. Annals of Oncology 2013;24:1777-85.

\section{Cohn 2013_ganit \{published data only\}}

Cohn AL, Tabernero J, Maurel J, Nowara E, Sastre J, Chuah BY, et al. A randomized, placebo-controlled phase 2 study of ganitumab or conatumumab in combination with FOLFIRI for second-line treatment of mutant KRAS metastatic colorectal cancer. Annals of Oncology 2013;24:1777-85.

\section{Cunningham 1998 \{published data only\}}

Cunningham D, Pyrhönen S, James RD, Punt CJA, Hickish TF, Heikkila R, et al. Randomised trial of irinotecan plus supportive care versus supportive care alone after fluorouracil failure for patients with metastatic colorectal cancer. Lancet 1998;352:1413-8.
Élez 2015 \{published data only\}

Élez E, Kocáková I, Höhler T, Martens UM, Bokemeyer C, Van Cutsem E, et al. Abituzumab combined with cetuximab plus irinotecan versus cetuximab plus irinotecan alone for patients with KRAS wild-type metastatic colorectal cancer: the randomised phase I/II POSEIDON trial. Annals of Oncology 2015;26:132-40.

\section{Fuchs 2003 \{published data only\}}

Fuchs CS, Moore MR, Harker G, Villa L, Rinaldi D, Hecht JR. Phase III comparison of two irinotecan dosing regimens in second-line therapy of metastatic colorectal cancer. Journal of Clinical Oncology 2003;21(5):807-14.

\section{Giantonio 2007 \{published data only\}}

Giantonio BJ, Catalano PJ, Meropol NJ, O'Dwyer PJ, Mitchell EP, Alberts SR, et al. Eastern Cooperative Oncology Group Study E3200. Bevacizumab in combination with oxaliplatin, fluorouracil, and leucovorin (FOLFOX4) for previously treated metastatic colorectal cancer: results from the Eastern Cooperative Oncology Group Study E3200. Journal of Clinical Oncology 2007;25:1539-44.

Gibbs 2011 \{published data only\}

Gibbs P, Clingan PR, Ganju V, Strickland AH, Wong SS, Tebbutt NC, et al. Hyaluronan-irinotecan improves progressionfree survival in 5-fluorouracil refractory patients with metastatic colorectal cancer: a randomized phase II trial. Cancer Chemotherapy and Pharmacology 2011;67(1):153-63.

Graeven 2007 \{published data only\}

Graeven U, Arnold D, Reinacher-Schick A, Heuer T, Nusch A, Porschen $\mathrm{R}$, et al. A randomised phase II study of irinotecan in combination with 5-FU/FA compared with irinotecan alone as second-line treatment of patients with metastatic colorectal carcinoma. Onkologie 2007;30(4):169-74.

\section{Haller 2008 \{published data only\}}

Haller DG, Rothenberg ML, Wong AO, Koralewski PM, Miller WH Jr, Bodoky G, et al. Oxaliplatin plus irinotecan compared with irinotecan alone as second-line treatment after single-agent fluoropyrimidine therapy for metastatic colorectal carcinoma. Journal of Clinical Oncology: Official Journal of the American Society of Clinical Oncology 2008;26(28):4544-50.

\section{Hecht 2015 \{published data only\}}

Hecht JR, Cohn A, Dakhil S, Saleh M, Piperdi B, ClineBurkhardt M, et al. SPIRITT: a randomized, multicenter, phase II study of panitumumab with FOLFIRI and bevacizumab with FOLFIRI as second-line treatment in patients with unresectable wild type KRAS metastatic colorectal cancer. Clinical Colorectal Cancer 2015;14:72-80.

\section{Iwamoto 2015 \{published data only\}}

Iwamoto S, Takahashi T, Tamagawa H, Nakamura M, Munemoto $\mathrm{Y}$, Kato T, et al. FOLFIRI plus bevacizumab as secondline therapy in patients with metastatic colorectal cancer after first-line bevacizumab plus oxaliplatin-based therapy: 
the randomized phase III EAGLE study. Annals of Oncology 2015;26:1427-33.

\section{Kim 2009 \{published data only\}}

Kim GP, Sargent DJ, Mahoney MR, Rowland KM Jr, Philip PA, Mitchell E, et al. Phase III noninferiority trial comparing irinotecan with oxaliplatin, fluorouracil, and leucovorin in patients with advanced colorectal carcinoma previously treated with fluorouracil: N9841. Journal of Clinical Oncology 2009;27(17):2848-54.

\section{Liu 2015 \{published data only\}}

Liu Y, Luan L, Wang X. A randomized phase II clinical study of combining panitumumab and bevacizumab, plus irinotecan, 5fluorouracil, and leucovorin (FOLFIRI) compared with FOLFIRI alone as second-line treatment for patients with metastatic colorectal cancer and KRAS mutation. Journal of OncoTargets and Therapy 2015;8:1061-8.

\section{Masi 2015 \{published data only\}}

Masi G, Salvatore L, Boni L, Loupakis F, Cremolini C, Fornaro L, et al. BEBYP Study Investigators. Continuation or reintroduction of bevacizumab beyond progression to first-line therapy in metastatic colorectal cancer: final results of the randomized BEBYP trial. Annals of Oncology 2015;26:724-30.

\section{Muro 2010 \{published data only\}}

Muro K, Boku N, Shimada Y, Tsuji A, Sameshima S, Baba H, et al. Irinotecan plus S-1 (IRIS) versus fluorouracil and folinic acid plus irinotecan (FOLFIRI) as second-line chemotherapy for metastatic colorectal cancer: a randomised phase 2/3 non-inferiority study (FIRIS study). Lancet Oncology 2010;11(9):853-60.

\section{O'Neil 2014 \{published data only\}}

O'Neil BH, Cainap C, Van Cutsem E, Gorbunova V, Karapetis CS, Berlin J, et al. Randomized phase II open-label study of mFOLFOX6 in combination with linifanib or bevacizumab for metastatic colorectal cancer. Clinical Colorectal Cancer 2014;13:156-63.

\section{Peeters 2010 \{published data only\}}

Peeters M, Price TJ, Cervantes A, Sobrero AF, Ducreux M, Hotko Y, et al. Randomized phase III study of panitumumab with fluorouracil, leucovorin, and irinotecan (FOLFIRI) compared with FOLFIRI alone as second-line treatment in patients with metastatic colorectal cancer. Journal of Clinical Oncology 2010;28:4706-13.

\section{Peeters 2013 \{published data only\}}

Peeters M, Strickland AH, Lichinitser M, Suresh AV, Manikhas G, Shapiro J, et al. A randomised, double-blind, placebocontrolled phase 2 study of trebananib (AMG 386) in combination with FOLFIRI in patients with previously treated metastatic colorectal carcinoma. British Journal of Cancer 2013;108:503-11.

\section{Price 2014 \{published data only\}}

Price TJ, Peeters M, Kim TW, Li J, Cascinu S, Ruff P, et al. Panitumumab versus cetuximab in patients with chemotherapy-refractory wild-type KRAS exon 2 metastatic colorectal cancer (ASPECCT): a randomised, multicentre, open-label, non-inferiority phase 3 study. Lancet Oncology 2014;15:569-79.

\section{Rothenberg 2003_folfox \{published data only\}}

Rothenberg ML, Oza AM, Bigelow RH, Berlin JD, Marshall JL, Ramanathan RK, et al. Superiority of oxaliplatin and fluorouracil-leucovorin compared with either therapy alone in patients with progressive colorectal cancer after irinotecan and fluorouracil-leucovorin: interim results of a phase III trial. Journal of Clinical Oncology 2003;21(11):2059-69.

\section{Rothenberg 2003_oxa \{published data only\}}

Rothenberg ML, Oza AM, Bigelow RH, Berlin JD, Marshall JL, Ramanathan RK, et al. Superiority of oxaliplatin and fluorouracil-leucovorin compared with either therapy alone in patients with progressive colorectal cancer after irinotecan and fluorouracil-leucovorin: interim results of a phase III trial. Journal of Clinical Oncology 2003;21(11):2059-69.

\section{Rothenberg 2008 \{published data only\}}

Rothenberg ML, Cox JV, Butts C, Navarro M, Bang YJ, Goel R, et al. Capecitabine plus oxaliplatin (XELOX) versus 5 -fluorouracil/ folinic acid plus oxaliplatin (FOLFOX-4) as second-line therapy in metastatic colorectal cancer: a randomized phase III noninferiority study. Annals of Oncology 2008;19:1720-6.

\section{Rougier 1998 \{published data only\}}

Rougier P, Van Cutsem E, Bajetta E, Niederle N, Possinger K, Labianca $R$, et al. Randomised trial of irinotecan versus fluorouracil by continuous infusion after fluorouracil failure in patients with metastatic colorectal cancer. Lancet 1998;352(9138):1407-12.

\section{Scheithauer 2002 \{published data only\}}

Scheithauer W, Kornek GV, Brugger S, Ullrich-Pur H, Valencak J, Raderer M, et al. Randomized phase II study of irinotecan plus mitomycin C vs. oxaliplatin plus mitomycin C in patients with advanced fluoropyrimidine/leucovorin-pretreated colorectal cancer. Cancer Investigation 2002;20(1):60-8.

\section{Seymour 2013 \{published data only\}}

Seymour MT, Brown SR, Middleton G, Maughan T, Richman S, Gwyther S, et al. Panitumumab and irinotecan versus irinotecan alone for patients with KRAS wild-type, fluorouracil-resistant advanced colorectal cancer (PICCOLO): a prospectively stratified randomised trial. Lancet Oncology 2013;14:749-59.

\section{Shoemaker 2004 \{published data only\}}

Schoemaker NE, Kuppens IELM, Moiseyenko V, Glimelius B, Kjaer M, Starkhammer H, et al. A randomised phase II multicentre trial of irinotecan (CPT-11) using four different schedules in patients with metastatic colorectal cancer. British Journal of Cancer 2004;91:1434-41.

\section{Sobrero 2008 \{published data only\}}

Sobrero AF, Maurel J, Fehrenbacher L, Scheithauer W, Abubakr YA, Lutz MP, et al. EPIC: phase III trial of cetuximab plus irinotecan after fluoropyrimidine and oxaliplatin failure in patients with metastatic colorectal cancer. Journal of Clinical Oncology 2008;26:2311-9. 
Tabernero 2015 \{published data only\}

Tabernero J, Yoshino T, Cohn AL, Obermannova R, Bodoky G, Garcia-Carbonero R, et al. RAISE Study Investigators.

Ramucirumab versus placebo in combination with second-line FOLFIRI in patients with metastatic colorectal carcinoma that progressed during or after first-line therapy with bevacizumab, oxaliplatin, and a fluoropyrimidine (RAISE): a randomised, double-blind, multicentre, phase 3 study. Lancet Oncology 2015;16:499-508.

\section{Tsavaris 2003 \{published data only\}}

Tsavaris N, Ziras N, Kosmas C, Giannakakis T, Gouveris P, Vadiaka M. Two different schedules of irinotecan (CPT-11) in patients with advanced colorectal carcinoma relapsing after a 5fluorouracil and leucovorin combination: a randomised study. Cancer Chemotherapy and Pharmacology 2003;52(6):514-9.

\section{Van Cutsem 2011 \{published data only\}}

Van Cutsem E, Bajetta E, Valle J, Köhne CH, Hecht JR, Moore M, et al. Randomized, placebo-controlled, phase III study of oxaliplatin, fluorouracil, and leucovorin with or without PTK787/ZK 222584 in patients with previously treated metastatic colorectal adenocarcinoma. Journal of Clinical Oncology 2011;29:2004-10.

\section{Van Cutsem 2012 \{published data only\}}

Van Cutsem E, Tabernero J, Lakomy R, Prenen H, Prausová J, Macarulla T, et al. Addition of aflibercept to fluorouracil, leucovorin, and irinotecan improves survival in a phase III randomized trial in patients with metastatic colorectal cancer previously treated with an oxaliplatin-based regimen. Journal of Clinical Oncology 2012;30:3499-506.

\section{Viéitez 2011 \{published data only\}}

Viéitez JM, Valladares M, Peláez I, de Sande González L, GarcíaFoncillas J, García-López JL, et al. A randomized phase II study of raltitrexed and gefitinib versus raltitrexed alone as second line chemotherapy in patients with colorectal cancer (1839IL/0143). Investigational New Drugs 2011;29:1038-44.

\section{References to studies excluded from this review}

Amado 2008 \{published data only\}

Amado RG, Wolf M, Peeters M, Van Cutsem E, Siena S, Freeman DJ, et al. Wild-type KRAS is required for panitumumab efficacy in patients with metastatic colorectal cancer. Journal of Clinical Oncology 2008;26:1626-34.

\section{Aranda 1998 \{published data only\}}

Aranda E, Díaz-Rubio E, Cervantes A, Antón-Torres A, Carrato A, Massutí $T$, et al. Randomized trial comparing monthly low-dose leucovorin and fluorouracil bolus with weekly high-dose 48hour continuous-infusion fluorouracil for advanced colorectal cancer: a Spanish Cooperative Group for Gastrointestinal Tumor Therapy (TTD) study. Annals of Oncology 1998;9:727-31.

\section{Chau 2004 \{published data only\}}

Chau I, Norman AR, Cunningham D, Waters JS, Topham C, Middleton $\mathrm{G}$, et al. Elderly patients with fluoropyrimidine and thymidylate synthase inhibitor-resistant advanced colorectal cancer derive similar benefit without excessive toxicity when treated with irinotecan monotherapy. British Journal of Cancer 2004;91(8):1453-8

\section{Chibaudel 2016 \{published data only\}}

Chibaudel B, Maindrault-Gœbel F, Bachet JB, Louvet C, Khalil A, Dupuis O, et al. PEPCOL: a GERCOR randomized phase II study of nanoliposomal irinotecan PEP02 (MM-398) or irinotecan with leucovorin/5-fluorouracil as second-line therapy in metastatic colorectal cancer. Cancer Medicine 2016;5:676-83.

\section{Comella 2000 \{published data only\}}

Comella P, De Vita F, Mancarella S, De Lucia L, Biglietto M, Casaretti $\mathrm{R}$, et al. Biweekly irinotecan or raltitrexed plus 6Sleucovorin and bolus 5-fluorouracil in advanced colorectal carcinoma: a Southern Italy Cooperative Oncology Group phase II-III randomized trial. Annals of Oncology 2000;11(10):1323-33.

\section{Comella 2002 \{published data only\}}

Comella P, Crucitta E, De Vita F, De Lucia L, Farris A, Del Gaizo F, et al. Addition of either irinotecan or methotrexate to bolus 5 -fluorouracil and high-dose folinic acid every 2 weeks in advanced colorectal carcinoma: a randomised study by the Southern Italy Cooperative Oncology Group. Annals of Oncology 2002;13(6):866-73.

\section{Cunningham 2004 \{published data only\}}

Cunningham D, Humblet $\mathrm{Y}$, Siena S, Khayat D, Bleiberg H, Santoro A, et al. Cetuximab monotherapy and cetuximab plus irinotecan in irinotecan-refractory metastatic colorectal cancer. New England Journal of Medicine 2004;351:337-45.

\section{Ducreux 2011 \{published data only\}}

Ducreux M, Malka D, Mendiboure J, Etienne PL, Texereau P, Auby $D$, et al. Fédération Francophone de Cancérologie Digestive (FFCD) 2000-05 Collaborative Group. Sequential versus combination chemotherapy for the treatment of advanced colorectal cancer (FFCD 2000-05): an open-label, randomised, phase 3 trial. Lancet Oncology 2011;12:1032-44.

\section{Garrett 2013 \{published data only\}}

Garrett CR, Bekaii-Saab TS, Ryan T, Fisher GA, Clive S, Kavan P, et al. Randomized phase 2 study of pegylated SN-38 (EZN-2208) or irinotecan plus cetuximab in patients with advanced colorectal cancer. Cancer 2013;119:4223-30.

\section{Grothey 2013 \{published data only\}}

Grothey A, Van Cutsem E, Sobrero A, Siena S, Falcone A, Ychou M, et al. CORRECT Study Group. Regorafenib monotherapy for previously treated metastatic colorectal cancer (CORRECT): an international, multicentre, randomised, placebo-controlled, phase 3 trial. Lancet Oncology 2013;381:303-12.

\section{Hendlisz 2010 \{published data only\}}

Hendlisz A, Van den Eynde M, Peeters M, Maleux G, Lambert B, Vannoote J, et al. Phase III trial comparing protracted intravenous fluorouracil infusion alone or with yttrium-90 resin microspheres radioembolization for liver-limited metastatic colorectal cancer refractory to standard chemotherapy. Journal of Clinical Oncology 2010;28:3687-94. 
Hurwitz 2004 \{published data only\}

Hurwitz H, Fehrenbacher L, Novotny W, Cartwright T, Hainsworth J, Heim W, et al. Bevacizumab plus irinotecan, fluorouracil, and leucovorin for metastatic colorectal cancer. New England Journal of Medicine 2004;350:2335-42.

\section{Jonker 2007 \{published data only\}}

Jonker DJ, O'Callaghan CJ, Karapetis CS, Zalcberg JR, Tu D, $\mathrm{Au} \mathrm{HJ}$, et al. Cetuximab for the treatment of colorectal cancer. New England Journal of Medicine 2007;357:2040-8.

\section{Kabbinavar 2003 \{published data only\}}

Kabbinavar F, Hurwitz HI, Fehrenbacher L, Meropol NJ, Novotny WF, Lieberman G, et al. Phase II, randomized trial comparing bevacizumab plus fluorouracil (FU)/leucovorin (LV) with FU/LV alone in patients with metastatic colorectal cancer . Journal of Clinical Oncology 2003;21:60-5.

\section{Kemeny 1993 \{published data only\}}

Kemeny N, Cohen A, Seiter K, Conti JA, Sigurdson ER, Tao Y, et al. Randomized trial of hepatic arterial floxuridine, mitomycin, and carmustine versus floxuridine alone in previously treated patients with liver metastases from colorectal cancer. Journal of Clinical Oncology 1993;11(2):330-5.

\section{Koopman 2007 \{published data only\}}

Koopman M, Antonini NF, Douma J, Wals J, Honkoop AH, Erdkamp FL, et al. Sequential versus combination chemotherapy with capecitabine, irinotecan, and oxaliplatin in advanced colorectal cancer (CAIRO): a phase III randomised controlled trial. Lancet 2007;370:135-42.

\section{Labianca 2011 \{published data only\}}

Labianca R, Sobrero A, Isa L, Cortesi E, Barni S, Nicolella D, et al. Italian Group for the Study of Gastrointestinal CancerGISCAD. Intermittent versus continuous chemotherapy in advanced colorectal cancer: a randomised 'GISCAD' trial. Annals of Oncology 2011;22:1236-42.

\section{Lacouture 2010 \{published data only\}}

Lacouture ME, Mitchell EP, Piperdi B, Pillai MV, Shearer H, lannotti N, et al. Skin toxicity evaluation protocol with panitumumab (STEPP), a phase II, open-label, randomized trial evaluating the impact of a pre-emptive skin treatment regimen on skin toxicities and quality of life in patients with metastatic colorectal cancer. Journal of Clinical Oncology 2010;28:1351-7.

\section{Lal 2004 \{published data only\}}

Lal R, Dickson J, Cunningham D, Chau I, Norman AR, Ross PJ, et al. A randomised trial comparing defined-duration with continuous irinotecan until disease progression in fluoropyrimidine and thymidylate synthase inhibitor-resistant advanced colorectal cancer. Journal of Clinical Oncology 2004;22(15):3023-31.

\section{Levi 1997 \{published data only\}}

Lévi F, Zidani R, Misset JL. Randomised multicentre trial of chronotherapy with oxaliplatin, fluorouracil, and folinic acid in metastatic colorectal cancer. Lancet 1997;350:681-6.

\section{Lin 2014 \{published data only\}}

Lin EH, Lenz HJ, Saleh MN, Mackenzie MJ, Knost JA, Pathiraja K, et al. A randomized, phase II study of the anti-insulin-like growth factor receptor type 1 (IGF-1R) monoclonal antibody robatumumab (SCH 717454) in patients with advanced colorectal cancer. Cancer Medicine 2014;3:988-97.

\section{Mandalá 2009 \{published data only\}}

Labianca R, Floriani I, Cortesi L, Zaniboni A, Marangolo M, et al. Alternating versus continuous "FOLFIRI" in advanced colorectal cancer (ACC): a randomized "GISCAD" trial. Journal of Clinical Oncology 2006;24 (Suppl):3505.

Mandalá M, Barni S, Floriani I, Isa L, Fornarini G, Marangolo M, et al. Incidence and clinical implications of venous thromboembolism in advanced colorectal cancer patients: the 'GISCAD-alternating schedule' study findings. European Journal of Cancer 2009;45(1):65-73.

\section{Maughan 2003 \{published data only\}}

Maughan TS, James RD, Kerr DJ, Ledermann JA, Seymour MT, Topham C, et al. Medical Research Council Colorectal Cancer Group. Comparison of intermittent and continuous palliative chemotherapy for advanced colorectal cancer: a multicentre randomised trial. Lancet 2003;361:457-64.

\section{Mayer 2015 \{published data only\}}

Mayer RJ, Van Cutsem E, Falcone A, Yoshino T, GarciaCarbonero R, Mizunuma N, et al. RECOURSE Study Group. Randomized trial of TAS-102 for refractory metastatic colorectal cancer. New England Journal of Medicine 2015;372:1909-19.

\section{Muro 2016 \{published data only\}}

Muro K, Kim T, Park Y, Uetake H, Nishina T, Nozawa H, et al. A multinational, randomized, phase III trial of XELIRI (+bevacizumab) versus FOLFIRI (+bevacizumab) as the secondline chemotherapy for metastatic colorectal cancer: Asian XELIRI project (AXEPT). Journal of Clinical Oncology 2016;Suppl 4S:TPS780.

\section{Rao 2004 \{published data only\}}

Rao S, Cunningham D, de Gramont A, Scheithauer W, Smakal M, Humblet $\mathrm{Y}$, et al. Phase III double-blind placebo-controlled study of farnesyl transferase inhibitor R115777 in patients with refractory advanced colorectal cancer. Journal of Clinical Oncology 2004;22(19):3950-7.

\section{Reidy 2010 \{published data only\}}

Reidy DL, Vakiani E, Fakih MG, Saif MW, Hecht JR, GoodmanDavis N, et al. Randomized, phase II study of the insulin-like growth factor-1 receptor inhibitor IMC-A12, with or without cetuximab, in patients with cetuximab- or panitumumabrefractory metastatic colorectal cancer. Journal of Clinical Oncology. 2010;28:4240-6.

\section{Rougier 2002 \{published data only\}}

Rougier P, Lepille D, Bennouna J, Marre A, Ducreux M, Mignot L, et al. Antitumour activity of three second-line treatment combinations in patients with metastatic colorectal cancer after optimal 5-FU regimen failure: a randomised, multicentre phase Il study. Annals of Oncology 2002;13:1558-67. 
Saltz 2000 \{published data only\}

Saltz LB, Cox JV, Blanke C, Rosen LS, Fehrenbacher L, Moore MJ, et al. Irinotecan plus fluorouracil and leucovorin for metastatic colorectal cancer. Irinotecan Study Group. New England Journal of Medicine 2000;343:905-14.

\section{Saltz 2007 \{published data only\}}

Saltz LB, Lenz HJ, Kindler HL, Hochster HS, Wadler S, Hoff PM, et al. Randomized phase II trial of cetuximab, bevacizumab, and irinotecan compared with cetuximab and bevacizumab alone in irinotecan-refractory colorectal cancer: the BOND-2 study. Journal of Clinical Oncology 2007;25:4557-61.

\section{Seymour 2007 \{published data only\}}

Seymour MT, Maughan TS, Ledermann JA, Topham C, James R, Gwyther SJ, et al for the FOCUS Trial Investigators and the National Cancer Research Institute Colorectal Clinical Studies Group. Different strategies of sequential and combination chemotherapy for patients with poor prognosis advanced colorectal cancer (MRC FOCUS): a randomised controlled trial. Lancet 2007;370:143-52.

\section{Siu 2013 \{published data only\}}

Siu LL, Shapiro JD, Jonker DJ, Karapetis CS, Zalcberg JR, Simes J, et al. Phase III randomized, placebo-controlled study of cetuximab plus brivanib alaninate versus cetuximab plus placebo in patients with metastatic, chemotherapy-refractory, wild-type K-RAS colorectal carcinoma: the NCIC Clinical Trials Group and AGITG CO.20 Trial. Journal of Clinical Oncology 2013;31:2477-84.

\section{Tournigand 2004 \{published data only\}}

Tournigand C, André T, Achille E, Lledo G, Flesh M, MeryMignard D, et al. FOLFIRI followed by FOLFOX6 or the reverse sequence in advanced colorectal cancer: a randomized GERCOR study. Journal of Clinical Oncology 2004;22:229-37.

\section{Tournigand 2006 \{published data only\}}

Tournigand C, Cervantes A, Figer A, Lledo G, Flesch M, Buyse M, et al. OPTIMOX1: a randomized study of FOLFOX4 or FOLFOX7 with oxaliplatin in a stop-and-Go fashion in advanced colorectal cancer--a GERCOR study. Journal of Clinical Oncology 2006;24:394-400.

\section{Tsavaris 2007 \{published data only\}}

Tsavaris N, Kosmas C, Skopelitis H, Papadoniou N, Polyzos A, Zografos $\mathrm{G}$, et al. Sequential administration of 5-fluorouracil (5FU)/leucovorin (LV) followed by irinotecan (CPT-11) at relapse versus CPT-11 followed by 5-FU/LV in advanced colorectal carcinoma. A phase III randomized study. Chemotherapy 2007;53(4):282-91.

\section{Van Cutsem 2005 \{published data only\}}

Van Cutsem E, Dirix L, Van Laethem JL, Van Belle S, Borner M, Gonzalez Baron M, et al. Optimisation of irinotecan dose in the treatment of patients with metastatic colorectal cancer after 5FU failure: results from a multinational, randomised phase II study. British Journal of Cancer 2005;92:1055-62.

\section{Van Cutsem 2007 \{published data only\}}

Van Cutsem E, Peeters M, Siena S, Humblet Y, Hendlisz A, Neyns B, et al. Open-label phase III trial of panitumumab plus best supportive care compared with best supportive care alone in patients with chemotherapy-refractory metastatic colorectal cancer. Journal of Clinical Oncology 2007;25:1658-64.

Van Cutsem 2012_bis \{published data only\}

Van Cutsem E, Tejpar S, Vanbeckevoort D, Peeters M, Humblet Y, Gelderblom $\mathrm{H}$, et al. Intrapatient cetuximab dose escalation in metastatic colorectal cancer according to the grade of early skin reactions: the randomized EVEREST study. Journal of Clinical Oncology 2012;30(23):2861-8.

\section{Van Cutsem 2014 \{published data only\}}

Van Cutsem E, Eng C, Nowara E, Swieboda-Sadlej A, Tebbutt NC, Mitchell E, et al. Randomized phase Ib/II trial of rilotumumab or ganitumab with panitumumab versus panitumumab alone in patients with wild-type KRAS metastatic colorectal cancer. Clinical Cancer Research 2014;20:4240-50.

\section{Yasui 2015 \{published data only\}}

Yasui H, Muro K, Shimada Y, Tsuji A, Sameshima S, Baba H, et al. A phase 3 non-inferiority study of 5-FU/l-leucovorin/ irinotecan (FOLFIRI) versus irinotecan/S-1 (IRIS) as secondline chemotherapy for metastatic colorectal cancer: updated results of the FIRIS study. Journal of Cancer Research in Clinical Oncology 2015;141:153-60.

\section{Yoshino 2012 \{published data only\}}

Yoshino T, Mizunuma N, Yamazaki K, Nishina T, Komatsu Y, Baba $\mathrm{H}$, et al. TAS-102 monotherapy for pretreated metastatic colorectal cancer: a double-blind, randomised, placebocontrolled phase 2 trial. Lancet Oncology 2012;13:993-1001.

\section{Additional references}

\section{Adam 2012}

Adam R, De Gramont A, Figueras J, Guthrie A, Kokudo N, Kunstlinger $F$, et al. The oncosurgery approach to managing liver metastases from colorectal cancer: a multidisciplinary international consensus. Oncologist 2012;17:1225-39.

\section{Altman 1999}

Altman DG, Andersen PK. Calculating the number needed to treat for trials where the outcome is time to an event. BMJ 1999;319:1492-5.

\section{Arnold 2013}

Arnold D, Stein A. New developments in the second-line treatment of metastatic colorectal cancer: potential place in therapy. Drugs 2013;73:883-91.

\section{Beretta 2013}

Beretta GD, Petrelli F, Stinco S, Cabiddu M, Ghilardi M, Squadroni M, et al. FOLFIRI + bevacizumab as second-line therapy for metastatic colorectal cancer pretreated with oxaliplatin: a pooled analysis of published trials. Medical Oncology 2013;30(1):486. 


\section{Best 2000}

Best P, Simmonds C, Baughan R, Buchanan R, Davis C, Fentiman I, et al. Palliative chemotherapy for advanced or metastatic colorectal cancer. Cochrane Database of Systematic Reviews 2000, Issue 1. [DOI: 10.1002/14651858.CD001545]

\section{Buyse 2007}

Buyse M, Burzykowski T, Carroll K, Michiels S, Sargent DJ, Miller LL, et al. Progression-free survival is a surrogate for survival in advanced colorectal cancer. Journal of Clinical Oncology 2007;25:5218-24.

\section{CTCAE}

Common Terminology Criteria for Adverse Events v3.0 (CTCAE). ctep.cancer.gov/reporting/ctc.html (accessed 16 October 2016).

\section{Cunningham 2010}

Cunningham D, Atkin W, Lenz HJ, Lynch HT, Minsky B, Nordlinger B, et al. Colorectal cancer. Lancet 2010;375:1030-47.

\section{Ferlay 2015}

Ferlay J, Soerjomataram I, Dikshit R, Eser S, Mathers C, Rebelo M, et al. Cancer incidence and mortality worldwide: sources, methods and major patterns in GLOBOCAN 2012. International Journal of Cancer 2015;136:E359-86.

\section{Giessen 2015}

Giessen C, Laubender RP, Ankerst DP, Stintzing S, Modest DP, Schulz C, et al. Surrogate endpoints in second-line treatment for mCRC: a systematic literature-based analysis from 23 randomised trials. Acta Oncologica 2015;54:187-93.

\section{Goldberg 2006}

Goldberg M. Therapy for metastatic colorectal cancer. Oncologist 2006;11:981-7.

\section{Grothey 2006}

Grothey A. Is there a third-line therapy for metastatic colorectal cancer?. Seminars in Oncology 2006;33(6 Suppl 11):S36-8.

\section{Gustavsson 2015}

Gustavsson B, Carlsson G, Machover D, Petrelli N, Roth A, Schmoll $\mathrm{HJ}$, et al. A review of the evolution of systemic chemotherapy in the management of colorectal cancer. Clinical Colorectal Cancer 2015;14:1-10.

\section{Guyatt 2011}

Guyatt GH, Oxman AD, Schunemann HJ, Tugwell P, Knottnerus A. GRADE guidelines: a new series of articles in the Journal of Clinical Epidemiology. Journal of Clinical Epidemiology 2011;64:380-2.

\section{Higgins 2003}

Higgins JP, Thompson SG, Deeks JJ, Altman DG. Measuring inconsistency in meta-analyses. BMJ 2003;327:557-60.

\section{Higgins 2011}

Higgins JPT, Green S (editors). Cochrane Handbook for Systematic Reviews of Interventions Version 5.1.0 (updated March 2011). The Cochrane Collaboration, 2011. Available from www.cochrane-handbook.org.

\section{Kirstein 2014}

Kirstein MM, Lange A, Prenzler A, Manns MP, Kubicka S, Vogel A. Targeted therapies in metastatic colorectal cancer: a systematic review and assessment of currently available data. Oncologist 2014;11:1156-68.

\section{Marques 2014}

Marques AM, Turner A, de Mello RA. Personalizing medicine for metastatic colorectal cancer: current developments. World Journal of Gastroenterology 2014;20:10425-31.

\section{NICE 2005}

National Institute for Health and Care Excellence. Colorectal cancer (advanced) - irinotecan, oxaliplatin and raltitrexed (review).www.nice.org.uk/TA093.pdf.

\section{Parmar 1998}

Parmar MKB, Torri V, Stewart L. Extracting summary statistics to perform meta-analyses of the published literature for survival endpoints. Statistics in Medicine 1998;17:2815-34.

\section{RevMan 2014 [Computer program]}

Nordic Cochrane Centre, The Cochrane Collaboration. Review Manager (RevMan). Version 5.3. Copenhagen: Nordic Cochrane Centre, The Cochrane Collaboration, 2014.

\section{Rougier 2005}

Rougier P, Lepere C. Second-line treatment of patients with metastatic colorectal cancer. Seminars in Oncology 2005;32(6 Suppl 9):S48-54.

\section{Saunders 2006}

Saunders M, Ivanson T. Management of advanced colorectal cancer: state of the art. British Journal of Cancer 2006;95:131-8.

\section{Schmoll 2012}

Schmoll HJ, Van Cutsem E, Stein A, Valentini V, Glimelius B, Haustermans $\mathrm{K}$, et al. ESMO consensus guidelines for management of patients with colon and rectal cancer. A personalized approach to clinical decision making. Annals Oncology 2012;23:2479-516.

\section{Sterne 2000}

Sterne JA, Gavaghan D, Egger M. Publication and related bias in meta-analysis: power of statistical tests and prevalence in the literature. Journal of Clinical Epidemiology 2000;53:1119-29.

\section{Therasse 2000}

Therasse P, Arbuck SG, Eisenhauer EA, Wanders J, Kaplan RS, Rubinstein L, et al. New guidelines to evaluate the response to treatment in solid tumors. Journal of the National Cancer Institute 2000;92(3):205-16.

\section{Torre 2015}

Torre LA, Bray F, Siegel RL, Ferlay J, Lortet-Tieulent J, Jemal A. Global cancer statistics, 2012. CA: A Cancer Journal for Clinicians 2015;65:87-108. 


\section{WHO 1979}

World Health Organization. Handbook for Reporting Results of Cancer Treatment. Geneva, Switzerland: World Health

Organization, 1979:15-22.

\section{CHARACTERISTICS OF STUDIES}

Characteristics of included studies [ordered by study ID]

\section{Bendell 2013_folfiri}

\begin{tabular}{ll} 
Methods & Parallel-group RCT (4-arm), open label, multicentre \\
\hline Participants & $\begin{array}{l}\text { People with metastatic CRC who did not respond to first-line therapy with oxaliplatin-containing regi- } \\
\text { men }\end{array}$ \\
& Mean age (years): 59 \\
& Males (\%): 47
\end{tabular}

Interventions $\quad$ Experimental group: axitinib + FOLFIRI $(n=49)$

Axitinib (small molecule tyrosine kinase inhibitor targeting VEGFR1-3, c-KIT and PDGFR): $5 \mathrm{mg}$ to $10 \mathrm{mg}$ twice daily, oral

Control group: bevacizumab + FOLFIRI $(n=51)$

Bevacizumab (blocking monoclonal antibody targeting VEGF): $5 \mathrm{mg} / \mathrm{kg}$ every 2 weeks, i.v.

Co-intervention: FOLFIRI (every 2 weeks, i.v.): irinotecan $\left(180 \mathrm{mg} / \mathrm{m}^{2}\right)+5 \mathrm{FU}\left(2800 \mathrm{mg} / \mathrm{m}^{2}\right)+$ leucovorin $\left(400 \mathrm{mg} / \mathrm{m}^{2}\right)$

\begin{tabular}{ll}
\hline Outcomes & OS, PFS, ORR, SAE \\
\hline Notes & Same publication as Bendell 2013_folfox (data split for presentation purposes only) \\
& Country: international (Western countries) \\
& Dropouts: none reported
\end{tabular}

\section{Risk of bias}

\begin{tabular}{lll}
\hline Bias & Authors' judgement & Support for judgement \\
\hline $\begin{array}{l}\text { Random sequence genera- } \\
\text { tion (selection bias) }\end{array}$ & Unclear risk & Unreported \\
\hline $\begin{array}{l}\text { Allocation concealment } \\
\text { (selection bias) }\end{array}$ & Unclear risk & Unreported \\
\hline $\begin{array}{l}\text { Blinding of participants } \\
\text { and personnel (perfor- } \\
\text { mance bias) } \\
\text { All outcomes }\end{array}$ & High risk & Open-label trial \\
\hline
\end{tabular}

Blinding of outcome as- High risk Open-label trial
sessment (detection bias) All outcomes
World Health Organization/International Agency for Research on Cancer. The World Cancer Report - the major findings. Central European Journal of Public Health 2003;11:177-9.

Incomplete outcome data Low risk We found no evidence of attrition bias
(attrition bias)


Bendell 2013_folfiri (Continued)

Efficacy outcomes

Incomplete outcome data Low risk $\quad$ We found no evidence of attrition bias
(attrition bias)

Safety and QoL outcomes

\begin{tabular}{lll}
$\begin{array}{l}\text { Selective reporting (re- } \\
\text { porting bias) }\end{array}$ & Low risk & We found no evidence of reporting bias \\
\hline Other bias? & Low risk & We found no evidence of other bias \\
\hline
\end{tabular}

Bendell 2013_folfox

\begin{tabular}{ll}
\hline Methods & Parallel-group RCT (4-arm), open label, multicentre, international \\
\hline Participants & $\begin{array}{l}\text { People with metastatic CRC who did not respond to first-line therapy with irinotecan-containing regi- } \\
\text { men } \\
\text { Mean age (years): } 59 \\
\text { Males (\%): } 47\end{array}$ \\
\hline
\end{tabular}

Interventions $\quad$ Experimental group: axitinib + FOLFOX $(n=36)$

Axitinib (small molecule tyrosine kinase inhibitor targeting multiple receptors such as VEGFR1-3, c-KIT and PDGFR): $5 \mathrm{mg}$ to $10 \mathrm{mg}$ twice daily, oral

Control group: bevacizumab + FOLFOX $(n=35)$

Bevacizumab (blocking monoclonal antibody targeting VEGF): $5 \mathrm{mg} / \mathrm{kg}$ every 2 weeks, i.v.

Co-intervention: FOLFOX (every 2 weeks, i.v.): oxaliplatin $\left(85 \mathrm{mg} / \mathrm{m}^{2}\right)+5 \mathrm{FU}\left(2800 \mathrm{mg} / \mathrm{m}^{2}\right)+$ leucovorin $\left(400 \mathrm{mg} / \mathrm{m}^{2}\right)$

\begin{tabular}{ll}
\hline Outcomes & OS, PFS, ORR, SAE \\
\hline Notes & Same publication as Bendell 2013_folfiri (data split for presentation purposes only) \\
& Country: international (Western countries) \\
& Dropouts: none reported
\end{tabular}

\section{Risk of bias}

\begin{tabular}{lll}
\hline Bias & Authors' judgement & Support for judgement \\
\hline $\begin{array}{l}\text { Random sequence genera- } \\
\text { tion (selection bias) }\end{array}$ & Unclear risk & Unreported \\
\hline $\begin{array}{l}\text { Allocation concealment } \\
\text { (selection bias) }\end{array}$ & Unclear risk & Unreported \\
\hline $\begin{array}{l}\text { Blinding of participants } \\
\text { and personnel (perfor- } \\
\text { mance bias) }\end{array}$ & High risk & Open-label trial \\
All outcomes & & \\
\hline
\end{tabular}


Bendell 2013_folfox (Continued)
Blinding of outcome as-
High risk
Open-label trial sessment (detection bias)
All outcomes

\begin{tabular}{lll}
\hline $\begin{array}{l}\text { Incomplete outcome data } \\
\text { (attrition bias) } \\
\text { Efficacy outcomes }\end{array}$ & Low risk & We found no evidence of attrition bias \\
\hline $\begin{array}{l}\text { Incomplete outcome data } \\
\text { (attrition bias) } \\
\text { Safety and QoL outcomes }\end{array}$ & Low risk & We found no evidence of attrition bias \\
\hline $\begin{array}{l}\text { Selective reporting (re- } \\
\text { porting bias) }\end{array}$ & Low risk & We found no evidence of reporting bias \\
\hline Other bias? & Low risk & We found no evidence of other bias \\
\hline
\end{tabular}

Bennouna 2013

\begin{tabular}{ll}
\hline Methods & Parallel-group RCT, open label, multicentre, international \\
\hline Participants & $\begin{array}{l}\text { People with metastatic CRC who did not respond to first-line therapy with oxaliplatin- or irinote- } \\
\text { can-containing regimen } \\
\text { Mean age (years): } 63 \\
\text { Males (\%): } 64\end{array}$ \\
\hline
\end{tabular}

Interventions $\quad$ Experimental group: bevacizumab + chemotherapy $(n=409)$

Bevacizumab (blocking monoclonal antibody targeting VEGF): $5 \mathrm{mg} / \mathrm{kg}$ every 2 weeks, i.v.

Control group: chemotherapy $(n=411)$

Chemotherapy: irinotecan- or oxaliplatin-containing regimen (switch with first-line regimen)

\begin{tabular}{ll}
\hline Outcomes & OS, PFS, ORR, SAE \\
\hline Notes & Country: international (Western countries) \\
& Dropouts: 4 (all in the combination regimen arm) \\
\hline
\end{tabular}

\section{Risk of bias}

\begin{tabular}{lll}
\hline Bias & Authors' judgement & Support for judgement \\
\hline $\begin{array}{l}\text { Random sequence genera- } \\
\text { tion (selection bias) }\end{array}$ & Low risk & Permuted block randomization by second-order minimization algorithm \\
\hline $\begin{array}{l}\text { Allocation concealment } \\
\text { (selection bias) }\end{array}$ & Low risk & Clinical and statistical teams were masked during the study \\
\hline $\begin{array}{l}\text { Blinding of participants } \\
\text { and personnel (perfor- } \\
\text { mance bias) }\end{array}$ & High risk \\
\begin{tabular}{l} 
All outcomes \\
\hline
\end{tabular}
\end{tabular}


Bennouna 2013 (Continued)
Blinding of outcome as-
High risk
Open-label trial sessment (detection bias)

All outcomes

\begin{tabular}{lll}
\hline $\begin{array}{l}\text { Incomplete outcome data } \\
\text { (attrition bias) } \\
\text { Efficacy outcomes }\end{array}$ & Low risk & We found no evidence of attrition bias \\
\hline $\begin{array}{l}\text { Incomplete outcome data } \\
\text { (attrition bias) } \\
\text { Safety and QoL outcomes }\end{array}$ & Low risk & We found no evidence of attrition bias \\
\hline $\begin{array}{l}\text { Selective reporting (re- } \\
\text { porting bias) }\end{array}$ & Low risk & We found no evidence of reporting bias \\
\hline Other bias? & Low risk & We found no evidence of other bias \\
\hline
\end{tabular}

\section{Cao 2015}

\begin{tabular}{ll}
\hline Methods & Parallel-group RCT, open label, multicentre, national \\
\hline Participants & $\begin{array}{l}\text { People with metastatic CRC who did not respond to first-line therapy with oxaliplatin-containing regi- } \\
\text { men } \\
\text { Mean age (years): } 62 \\
\text { Males (\%): } 62\end{array}$ \\
\hline
\end{tabular}

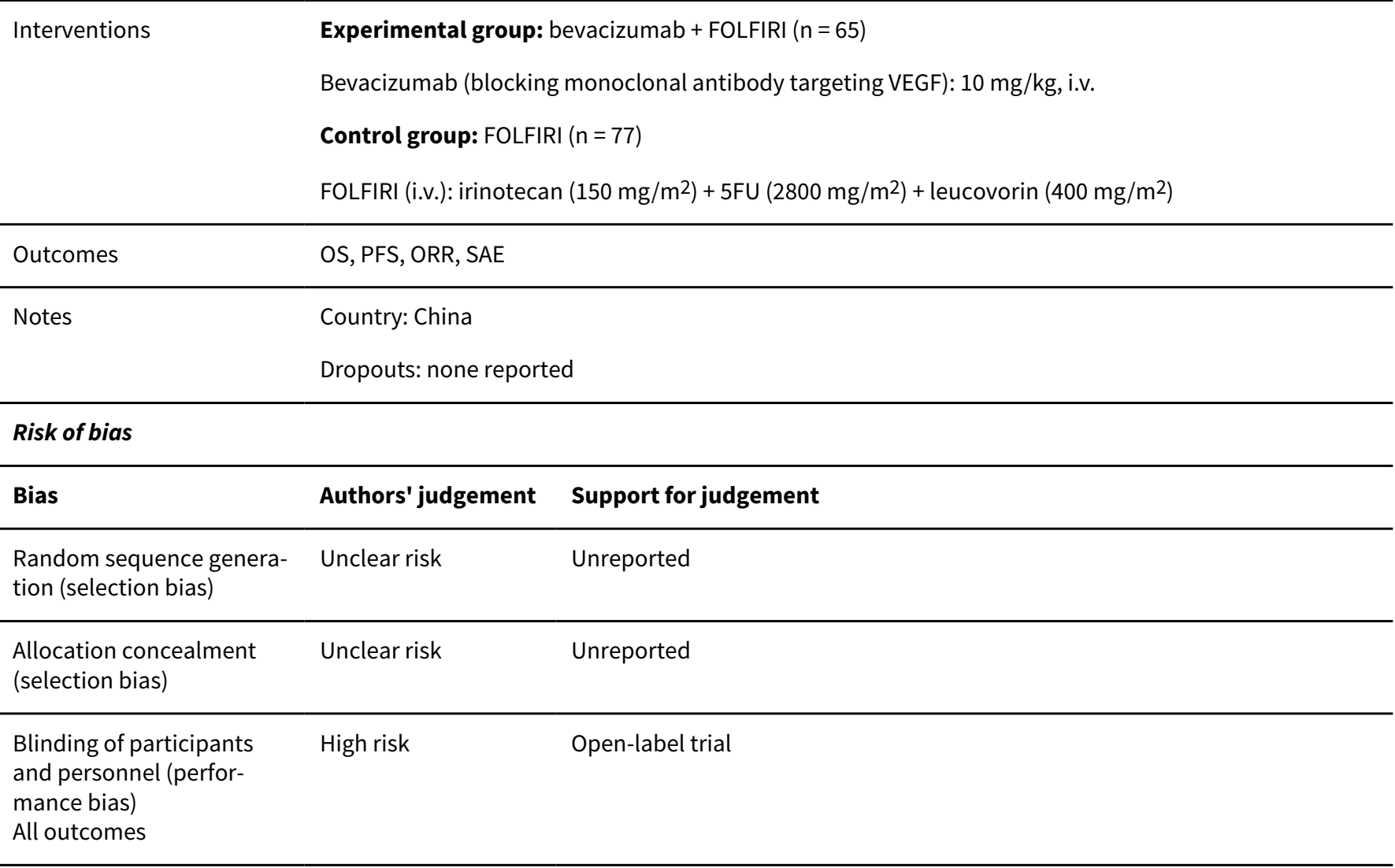


Cao 2015 (Continued)

Blinding of outcome as- High risk Open-label trial sessment (detection bias)

All outcomes

\begin{tabular}{lll}
\hline $\begin{array}{l}\text { Incomplete outcome data } \\
\text { (attrition bias) } \\
\text { Efficacy outcomes }\end{array}$ & Low risk & We found no evidence of attrition bias \\
\hline $\begin{array}{l}\text { Incomplete outcome data } \\
\text { (attrition bias) } \\
\text { Safety and QoL outcomes }\end{array}$ & Low risk & We found no evidence of attrition bias \\
\hline $\begin{array}{l}\text { Selective reporting (re- } \\
\text { porting bias) }\end{array}$ & Low risk & We found no evidence of reporting bias \\
\hline Other bias? & Low risk & We found no evidence of other bias \\
\hline
\end{tabular}

\section{Clarke 2011}

\begin{tabular}{ll}
\hline Methods & Parallel-group RCT, multicentre, national \\
\hline Participants & People with metastatic CRC who did not respond to first-line therapy with 5FU-containing regimen \\
Mean age (years): unreported \\
Males (\%): 60
\end{tabular}

Interventions Experimental group: FOLFIRI $(n=44)$

FOLFIRI (i.v., every 2 weeks): irinotecan $\left(180 \mathrm{mg} / \mathrm{m}^{2}\right)+5 \mathrm{FU}\left(2800 \mathrm{mg} / \mathrm{m}^{2}\right)+$ leucovorin $\left(20 \mathrm{mg} / \mathrm{m}^{2}\right)$

Control group: irinotecan $(n=45)$

Irinotecan: 300 or $350 \mathrm{mg} / \mathrm{m}^{2}$, i.v., every 3 weeks

\begin{tabular}{ll}
\hline Outcomes & OS, PFS, ORR, SAE, QoL \\
\hline Notes & Country: Australia \\
& Dropouts: 4 (2 in each arm)
\end{tabular}

\section{Risk of bias}

\begin{tabular}{lll}
\hline Bias & Authors' judgement & Support for judgement \\
\hline $\begin{array}{l}\text { Random sequence genera- } \\
\text { tion (selection bias) }\end{array}$ & Low risk & Randomization by minimization method \\
\hline $\begin{array}{l}\text { Allocation concealment } \\
\text { (selection bias) }\end{array}$ & Low risk & Participants were randomized centrally by telephone \\
\hline $\begin{array}{l}\text { Blinding of participants } \\
\text { and personnel (perfor- } \\
\text { mance bias) }\end{array}$ & Unclear risk & Unreported \\
All outcomes & & \\
\hline
\end{tabular}


Clarke 2011 (Continued)

Blinding of outcome as-
sessment (detection bias)

All outcomes

\begin{tabular}{lll}
\hline $\begin{array}{l}\text { Incomplete outcome data } \\
\text { (attrition bias) } \\
\text { Efficacy outcomes }\end{array}$ & Low risk & $\begin{array}{l}\text { Only 1 participant explicitly asking not to be analyzed (irinotecan arm) was ex- } \\
\text { cluded }\end{array}$ \\
\hline $\begin{array}{l}\text { Incomplete outcome data } \\
\text { (attrition bias) } \\
\text { Safety and QoL outcomes }\end{array}$ & Low risk & We found no evidence of attrition bias \\
\hline $\begin{array}{l}\text { Selective reporting (re- } \\
\text { porting bias) }\end{array}$ & Low risk & We found no evidence of reporting bias \\
\hline Other bias? & Low risk & We found no evidence of other bias \\
\hline
\end{tabular}

\section{Cohn 2013_conat}

\begin{tabular}{ll}
\hline Methods & Parallel-group RCT (3-arm), double blind, multicentre, international \\
\hline Participants & $\begin{array}{l}\text { People with mutant KRAS metastatic CRC who did not respond to first-line therapy with oxaliplatin } \\
\text { (with or without bevacizumab)-containing regimen } \\
\text { Mean age (years): } 59 \\
\text { Males (\%): } 51\end{array}$ \\
\hline
\end{tabular}

Experimental group: conatumumab + FOLFIRI $(\mathrm{n}=51)$
Conatumumab (agonistic monoclonal antibody targeting DR5 (death receptor 5)): $10 \mathrm{mg} / \mathrm{kg}$, i.v., every
2 weeks

Control group: placebo + FOLFIRI $(n=52)$

FOLFIRI: (i.v., every 2 weeks): irinotecan $\left(180 \mathrm{mg} / \mathrm{m}^{2}\right)+5 F U\left(2800 \mathrm{mg} / \mathrm{m}^{2}\right)+$ leucovorin $\left(400 \mathrm{mg} / \mathrm{m}^{2}\right)$

\begin{tabular}{ll}
\hline Outcomes & OS, PFS, ORR, SAE \\
\hline Notes & Same publication as Cohn 2013_ganit (data split for presentation purposes only) \\
& Country: international (mainly Western countries) \\
& Dropouts: none reported \\
\hline
\end{tabular}

\section{Risk of bias}

\begin{tabular}{lll}
\hline Bias & Authors' judgement & Support for judgement \\
\hline $\begin{array}{l}\text { Random sequence genera- } \\
\text { tion (selection bias) }\end{array}$ & Low risk & Permutated blocks randomization \\
\hline $\begin{array}{l}\text { Allocation concealment } \\
\text { (selection bias) }\end{array}$ & Low risk & Centralized randomization (interactive voice response system) \\
\hline
\end{tabular}


Cohn 2013_conat (Continued)
Blinding of participants
Low risk
Double-blind trial and personnel (perfor- mance bias)
All outcomes

\begin{tabular}{|c|c|c|}
\hline $\begin{array}{l}\text { Blinding of outcome as- } \\
\text { sessment (detection bias) } \\
\text { All outcomes }\end{array}$ & Unclear risk & Unreported \\
\hline
\end{tabular}

\begin{tabular}{lll}
\hline $\begin{array}{l}\text { Incomplete outcome data } \\
\text { (attrition bias) } \\
\text { Efficacy outcomes }\end{array}$ & Low risk & We found no evidence of attrition bias \\
\hline $\begin{array}{l}\text { Incomplete outcome data } \\
\text { (attrition bias) } \\
\text { Safety and QoL outcomes }\end{array}$ & Low risk & We found no evidence of attrition bias \\
\hline $\begin{array}{l}\text { Selective reporting (re- } \\
\text { porting bias) }\end{array}$ & Low risk & We found no evidence of reporting bias \\
\hline Other bias? & Low risk & We found no evidence of other bias \\
\hline
\end{tabular}

Cohn 2013_ganit

\begin{tabular}{ll}
\hline Methods & Parallel-group RCT (3-arm), double blind, multicentre, international \\
\hline Participants & $\begin{array}{l}\text { People with mutant KRAS metastatic CRC who did not respond to first-line therapy with oxaliplatin } \\
\text { (with or without bevacizumab)-containing regimen } \\
\text { Mean age (years): } 59 \\
\text { Males (\%): } 51\end{array}$ \\
\hline
\end{tabular}

Interventions $\quad$ Experimental group: ganitumab + FOLFIRI $(n=51)$

Ganitumab (blocking monoclonal antibody targeting insulin-like growth factor 1 receptor (IGF1R)): 12 $\mathrm{mg} / \mathrm{kg}$, i.v., every 2 weeks

Control group: placebo + FOLFIRI $(n=52)$

FOLFIRI: (i.v., every 2 weeks): irinotecan $\left(180 \mathrm{mg} / \mathrm{m}^{2}\right)+5 \mathrm{FU}\left(2800 \mathrm{mg} / \mathrm{m}^{2}\right)+$ leucovorin $\left(400 \mathrm{mg} / \mathrm{m}^{2}\right)$

\begin{tabular}{|c|c|c|}
\hline Outcomes & OS, PFS, ORR, SAE & \\
\hline \multirow[t]{3}{*}{ Notes } & \multicolumn{2}{|c|}{ Same publication as Cohn 2013_conat (data split for presentation purposes only) } \\
\hline & \multicolumn{2}{|c|}{ Country: international (mainly Western countries) } \\
\hline & \multicolumn{2}{|c|}{ Dropouts: none reported } \\
\hline \multicolumn{3}{|l|}{ Risk of bias } \\
\hline Bias & Authors' judgement & Support for judgement \\
\hline $\begin{array}{l}\text { Random sequence genera- } \\
\text { tion (selection bias) }\end{array}$ & Low risk & Permutated blocks randomization \\
\hline
\end{tabular}


Cohn 2013_ganit (Continued)

\begin{tabular}{lll}
$\begin{array}{l}\text { Allocation concealment } \\
\text { (selection bias) }\end{array}$ & Low risk & Centralized randomization (interactive voice response system) \\
\hline $\begin{array}{l}\text { Blinding of participants } \\
\text { and personnel (perfor- }\end{array}$ & Low risk & Double-blind trial \\
$\begin{array}{l}\text { mance bias) } \\
\text { All outcomes }\end{array}$ &
\end{tabular}

\begin{tabular}{lll}
\hline $\begin{array}{l}\text { Blinding of outcome as- } \\
\text { sessment (detection bias) } \\
\text { All outcomes }\end{array}$ & Unclear risk & Unreported \\
\hline $\begin{array}{l}\text { Incomplete outcome data } \\
\text { (attrition bias) } \\
\text { Efficacy outcomes }\end{array}$ & Low risk & We found no evidence of attrition bias \\
\hline $\begin{array}{l}\text { Incomplete outcome data } \\
\text { (attrition bias) }\end{array}$ & Low risk & We found no evidence of attrition bias \\
\hline $\begin{array}{l}\text { Safety and QoL outcomes } \\
\text { Selective reporting (re- } \\
\text { porting bias) }\end{array}$ & Low risk & We found no evidence of reporting bias \\
\hline \begin{tabular}{l} 
Other bias? \\
\hline
\end{tabular}
\end{tabular}

Cunningham 1998

\begin{tabular}{ll}
\hline Methods & Parallel-group RCT, open label, multicentre, international \\
\hline Participants & $\begin{array}{l}\text { People with metastatic CRC who did not respond to first-line therapy with 5FU. Some participants } \\
(24 \%) \text { had received } \geq 2 \text { previous chemotherapy regimens } \\
\text { Mean age (years): } 61 \\
\text { Males (\%): } 66\end{array}$ \\
\hline
\end{tabular}

Interventions

Experimental group: irinotecan $(n=189)$

Irinotecan: $350 \mathrm{mg} / \mathrm{m}^{2}$ i.v. every 21 days

Control group: best supportive care $(n=90)$

\begin{tabular}{|c|c|c|}
\hline Outcomes & \multicolumn{2}{|l|}{ OS, SAE, QoL } \\
\hline \multirow[t]{2}{*}{ Notes } & \multicolumn{2}{|c|}{ Country: international (Western countries) } \\
\hline & \multicolumn{2}{|c|}{ Dropouts: 10 (5 in each arm) } \\
\hline \multicolumn{3}{|l|}{ Risk of bias } \\
\hline Bias & Authors' judgement & Support for judgement \\
\hline $\begin{array}{l}\text { Random sequence genera- } \\
\text { tion (selection bias) }\end{array}$ & Low risk & Random sequence was generated electronically \\
\hline
\end{tabular}


Cunningham 1998 (Continued)

\begin{tabular}{lll}
$\begin{array}{l}\text { Allocation concealment } \\
\text { (selection bias) }\end{array}$ & Low risk & Centralized randomization \\
\hline $\begin{array}{l}\text { Blinding of participants } \\
\text { and personnel (perfor- }\end{array}$ & High risk & Open-label trial \\
$\begin{array}{l}\text { mance bias) } \\
\text { All outcomes }\end{array}$ &
\end{tabular}

\begin{tabular}{lll}
\hline $\begin{array}{l}\text { Blinding of outcome as- } \\
\text { sessment (detection bias) } \\
\text { All outcomes }\end{array}$ & High risk & Open-label trial \\
\hline $\begin{array}{l}\text { Incomplete outcome data } \\
\text { (attrition bias) } \\
\text { Efficacy outcomes }\end{array}$ & Low risk & We found no evidence of attrition bias \\
\hline $\begin{array}{l}\text { Incomplete outcome data } \\
\text { (attrition bias) }\end{array}$ & Low risk & We found no evidence of attrition bias \\
$\begin{array}{l}\text { Safety and QoL outcomes } \\
\begin{array}{l}\text { Selective reporting (re- } \\
\text { porting bias) }\end{array}\end{array}$ & Low risk & We found no evidence of reporting bias \\
\hline $\begin{array}{l}\text { Other bias? } \\
\text { Unclear risk }\end{array}$ & $\begin{array}{l}\text { "Characteristics were similar for both groups except for performance status } \\
\text { (more patients having poor performance status in the supportive-care group) } \\
\text { and anaemia." }\end{array}$ \\
\hline
\end{tabular}

Fuchs 2003

\begin{tabular}{ll}
\hline Methods & Parallel-group RCT, open label, multicentre, national \\
\hline Participants & People with metastatic CRC who did not respond to first-line therapy with 5FU \\
& Mean age (years): 62 \\
& Males (\%): 61 \\
\hline
\end{tabular}

Interventions $\quad$ Experimental group: irinotecan schedule-1 $(n=196)$

Irinotecan schedule-1 (single dose): $350 \mathrm{mg} / \mathrm{m}^{2}$ i.v. every 3 weeks

Control group: irinotecan schedule-2 $(n=95)$

Irinotecan schedule-2 (fractionated): $125 \mathrm{mg} / \mathrm{m}^{2}$ weekly during 4 weeks every 6 weeks

\begin{tabular}{ll}
\hline Outcomes & OS, PFS, SAE, QoL \\
\hline Notes & Country: USA \\
& Dropouts: none reported \\
\hline
\end{tabular}

\section{Risk of bias}


Fuchs 2003 (Continued)

\begin{tabular}{lll}
$\begin{array}{l}\text { Random sequence genera- } \\
\text { tion (selection bias) }\end{array}$ & Low risk & Random sequence was generated electronically \\
\hline $\begin{array}{l}\text { Allocation concealment } \\
\text { (selection bias) }\end{array}$ & Unclear risk & Unreported \\
\hline $\begin{array}{l}\text { Blinding of participants } \\
\text { and personnel (perfor- } \\
\text { mance bias) }\end{array}$ & High risk & Open-label trial \\
All outcomes & & \\
\hline
\end{tabular}

\begin{tabular}{|c|c|c|}
\hline $\begin{array}{l}\text { Blinding of outcome as- } \\
\text { sessment (detection bias) } \\
\text { All outcomes }\end{array}$ & High risk & Open-label trial \\
\hline $\begin{array}{l}\text { Incomplete outcome data } \\
\text { (attrition bias) } \\
\text { Efficacy outcomes }\end{array}$ & Low risk & We found no evidence of attrition bias \\
\hline $\begin{array}{l}\text { Incomplete outcome data } \\
\text { (attrition bias) } \\
\text { Safety and QoL outcomes }\end{array}$ & Low risk & $\begin{array}{l}\text { "A total of seven patients, one on the weekly schedule and six on the every-3- } \\
\text { weeks regimen, received no irinotecan and were excluded from the tolerability } \\
\text { analysis." Reasons for not receiving treatment are described }\end{array}$ \\
\hline $\begin{array}{l}\text { Selective reporting (re- } \\
\text { porting bias) }\end{array}$ & Low risk & We found no evidence of reporting bias \\
\hline Other bias? & Low risk & We found no evidence of other bias \\
\hline
\end{tabular}

Giantonio 2007

\begin{tabular}{ll}
\hline Methods & Parallel-group RCT, open label, multicentre, international \\
\hline Participants & People with metastatic CRC who did not respond to first-line therapy with FOLFIRI \\
& Mean age (years): 60 \\
& Males (\%): 60 \\
\hline
\end{tabular}

Interventions Experimental group: bevacizumab + FOLFOX4 $(n=286)$

Bevacizumab (blocking monoclonal antibody targeting VEGF): $10 \mathrm{mg} / \mathrm{kg}$, i.v., every 2 weeks

Control group: FOLFOX4 $(n=291)$

FOLFOX4 (i.v., every 2 weeks): oxaliplatin $\left(85 \mathrm{mg} / \mathrm{m}^{2}\right)+5 F U\left(1000 \mathrm{mg} / \mathrm{m}^{2}\right)+$ leucovorin $\left(200 \mathrm{mg} / \mathrm{m}^{2}\right)$

\begin{tabular}{ll}
\hline Outcomes & OS, PFS, ORR, SAE \\
\hline Notes & Country: international (mainly USA) \\
& Dropouts: 6 (number per arm: unreported) \\
\hline Risk of bias & Authors' judgement Support for judgement \\
\hline Bias &
\end{tabular}


Giantonio 2007 (Continued)

\begin{tabular}{lll}
$\begin{array}{l}\text { Random sequence genera- } \\
\text { tion (selection bias) }\end{array}$ & Unclear risk & Unreported \\
\hline $\begin{array}{l}\text { Allocation concealment } \\
\text { (selection bias) }\end{array}$ & Unclear risk & Unreported \\
\hline $\begin{array}{l}\text { Blinding of participants } \\
\text { and personnel (perfor- } \\
\text { mance bias) }\end{array}$ & High risk & Open-label trial \\
All outcomes & & \\
\hline
\end{tabular}

\begin{tabular}{lll}
\hline Blinding of outcome as- & High risk & Open-label trial \\
sessment (detection bias)
\end{tabular}

All outcomes

Incomplete outcome data Low risk $\quad$ We found no evidence of attrition bias
(attrition bias)

\section{Efficacy outcomes}

Incomplete outcome data Low risk We found no evidence of attrition bias

(attrition bias)

Safety and QoL outcomes

\begin{tabular}{lll}
\hline $\begin{array}{l}\text { Selective reporting (re- } \\
\text { porting bias) }\end{array}$ & Low risk & We found no evidence of reporting bias \\
\hline Other bias? & Low risk & We found no evidence of other bias \\
\hline
\end{tabular}

Gibbs 2011

\begin{tabular}{ll}
\hline Methods & Parallel-group RCT, open-label, multicentre, national \\
\hline Participants & People with metastatic CRC who did not respond to first-line therapy with 5FU without oxaliplatin \\
& Mean age (years): 63 \\
& Males (\%): 59 \\
\hline Interventions & Experimental group: hyaluronan-irinotecan $(\mathrm{n}=41)$ \\
& Hyaluronan-irinotecan (i.v., every 3 weeks): hyaluronan $\left(1000 \mathrm{mg} / \mathrm{m}^{2}\right)+$ irinotecan $\left(350 \mathrm{mg} / \mathrm{m}^{2}\right)$ \\
& Control group: irinotecan ( $\mathrm{n}=35)$ \\
& Irinotecan: 350 mg/m², i.v., every 3 weeks \\
\hline Outcomes & OS, PFS, ORR, SAE \\
\hline Notes & Country: Australia \\
& Dropouts: none reported \\
\hline
\end{tabular}

\section{Risk of bias}

Bias Authors' judgement Support for judgement


Gibbs 2011 (Continued)

\begin{tabular}{lll}
$\begin{array}{l}\text { Random sequence genera- } \\
\text { tion (selection bias) }\end{array}$ & Unclear risk & Unreported \\
\hline $\begin{array}{l}\text { Allocation concealment } \\
\text { (selection bias) }\end{array}$ & Unclear risk & Unreported \\
\hline $\begin{array}{l}\text { Blinding of participants } \\
\begin{array}{l}\text { and personnel (perfor- } \\
\text { mance bias) }\end{array}\end{array}$ & High risk & Open-label trial \\
All outcomes & & \\
\hline
\end{tabular}

\begin{tabular}{lll}
\hline $\begin{array}{l}\text { Blinding of outcome as- } \\
\text { sessment (detection bias) } \\
\text { All outcomes }\end{array}$ & High risk & Open-label trial \\
\hline $\begin{array}{l}\text { Incomplete outcome data } \\
\text { (attrition bias) } \\
\text { Efficacy outcomes }\end{array}$ & Low risk & We found no evidence of attrition bias \\
\hline $\begin{array}{l}\text { Incomplete outcome data } \\
\text { (attrition bias) } \\
\text { Safety and QoL outcomes }\end{array}$ & Low risk & We found no evidence of attrition bias \\
\hline $\begin{array}{l}\text { Selective reporting (re- } \\
\text { porting bias) }\end{array}$ & Low risk & We found no evidence of reporting bias \\
\hline \begin{tabular}{l} 
Other bias? \\
\hline
\end{tabular} & Low risk & We found no evidence of other bias \\
\hline
\end{tabular}

\section{Graeven 2007}

\begin{tabular}{ll}
\hline Methods & Parallel-group RCT, open-label, multicentre, national \\
\hline Participants & People with metastatic CRC who did not respond to first-line therapy with 5FU without oxaliplatin \\
& Mean age (years): 66 \\
& Males (\%): 64 \\
\hline
\end{tabular}

\begin{tabular}{ll} 
Interventions & Experimental group: FOLFIRI $(\mathrm{n}=28)$ \\
& FOLFIRI (i.v., every 7 weeks): irinotecan $\left(80 \mathrm{mg} / \mathrm{m}^{2}\right)+$ leucovorin $\left(500 \mathrm{mg} / \mathrm{m}^{2}\right)+5 \mathrm{FU}\left(2000 \mathrm{mg} / \mathrm{m}^{2}\right)$ \\
& Control group: irinotecan $(\mathrm{n}=27)$ \\
& Irinotecan: $125 \mathrm{mg} / \mathrm{m}^{2}$, i.v., every 6 weeks \\
\hline Outcomes & OS, PFS, ORR, SAE \\
\hline Notes & Country: Germany \\
& Dropouts: none reported
\end{tabular}

\section{Risk of bias}

Bias Authors' judgement Support for judgement


Graeven 2007 (Continued)

\begin{tabular}{lll}
$\begin{array}{l}\text { Random sequence genera- } \\
\text { tion (selection bias) }\end{array}$ & Unclear risk & Unreported \\
\hline $\begin{array}{l}\text { Allocation concealment } \\
\text { (selection bias) }\end{array}$ & Unclear risk & Unreported \\
\hline $\begin{array}{l}\text { Blinding of participants } \\
\text { and personnel (perfor- } \\
\text { mance bias) }\end{array}$ & High risk & Open-label tria \\
All outcomes & &
\end{tabular}

\begin{tabular}{lll}
$\begin{array}{l}\text { Blinding of outcome as- } \\
\text { sessment (detection bias) } \\
\text { All outcomes }\end{array}$ & High risk & Open-label trial \\
\hline $\begin{array}{l}\text { Incomplete outcome data } \\
\text { (attrition bias) }\end{array}$ & High risk & $\begin{array}{l}\text { "Efficacy analyses were based on an intent-to-treat population". } 57 \text { patients } \\
\text { were enrolled into this multicentre study. } 2 \text { patients were withdrawn prior to } \\
\text { the first administration. Therefore, the intent-to-treat population includes } 55 \\
\text { patients. Overall survival and PFS are presented for } 55 \text { participants. Neither } \\
\text { the arm the two patients belonged to, nor the reasons for withdrawal were re- } \\
\text { ported }\end{array}$ \\
$\begin{array}{l}\text { "39 patients were evaluable for response", therefore the intention-to-treat } \\
\text { population includes } 16 \text { no evaluable participants }\end{array}$
\end{tabular}

\begin{tabular}{lll}
\hline $\begin{array}{l}\text { Incomplete outcome data } \\
\text { (attrition bias) } \\
\text { Safety and QoL outcomes }\end{array}$ & Low risk & We found no evidence of attrition bias \\
\hline $\begin{array}{l}\text { Selective reporting (re- } \\
\text { porting bias) }\end{array}$ & Low risk & We found no evidence of reporting bias \\
\hline Other bias? & Low risk & We found no evidence of other bias \\
\hline
\end{tabular}

Haller 2008

\begin{tabular}{ll}
\hline Methods & Parallel-group RCT, open-label, multicentre, international \\
\hline Participants & $\begin{array}{l}\text { People with metastatic CRC who did not respond to first-line therapy with 5FU or capecitabine without } \\
\text { leucovorin } \\
\text { Mean age (years): } 62 \\
\text { Males (\%): } 60\end{array}$ \\
\hline
\end{tabular}

\begin{tabular}{ll}
\hline Interventions & Experimental group: IROX (irinotecan + oxaliplatin) $(\mathrm{n}=317)$ \\
& IROX (i.v., every 3 weeks): oxaliplatin $\left(85 \mathrm{mg} / \mathrm{m}^{2}\right)+$ irinotecan $\left(200 \mathrm{mg} / \mathrm{m}^{2}\right)$ \\
& Control group: irinotecan $(\mathrm{n}=310)$ \\
& Irinotecan: $350 \mathrm{mg} / \mathrm{m}^{2}$ (i.v., every 3 weeks) \\
\hline Outcomes & OS, PFS, ORR, SAE \\
\hline Notes & Country: international (mainly Western countries)
\end{tabular}


Haller 2008 (Continued)

Dropouts: 14 (5 in IROX arm; 9 in irinotecan arm)

\section{Risk of bias}

\begin{tabular}{lll}
\hline Bias & Authors' judgement & Support for judgement \\
\hline $\begin{array}{l}\text { Random sequence genera- } \\
\text { tion (selection bias) }\end{array}$ & Low risk & Central randomization by interactive voice response system \\
\hline
\end{tabular}

tion (selection bias)

\begin{tabular}{l}
$\begin{array}{l}\text { Allocation concealment } \\
\text { (selection bias) }\end{array} \quad$ Low risk Central randomization by interactive voice response system \\
\hline
\end{tabular}

Blinding of participants High risk $\quad$ Open-label trial
and personnel (perfor-
mance bias)
All outcomes

\begin{tabular}{lll}
\hline $\begin{array}{l}\text { Blinding of outcome as- } \\
\text { sessment (detection bias) } \\
\text { All outcomes }\end{array}$ & High risk & Open-label trial \\
\hline $\begin{array}{l}\text { Incomplete outcome data } \\
\text { (attrition bias) } \\
\text { Efficacy outcomes }\end{array}$ & Low risk & We found no evidence of attrition bias \\
\hline $\begin{array}{l}\text { Incomplete outcome data } \\
\text { (attrition bias) } \\
\text { Safety and QoL outcomes }\end{array}$ & Low risk & We found no evidence of attrition bias \\
\hline $\begin{array}{l}\text { Selective reporting (re- } \\
\text { porting bias) }\end{array}$ & Low risk & We found no evidence of reporting bias \\
\hline \begin{tabular}{l} 
Other bias? \\
\hline
\end{tabular}
\end{tabular}

Hecht 2015

\begin{tabular}{ll}
\hline Methods & Parallel-group RCT, open-label, multicentre, national \\
\hline Participants & $\begin{array}{l}\text { People with wild-type KRAS metastatic CRC who did not respond to first-line therapy with FOLFOX + be- } \\
\text { vacizumab } \\
\text { Mean age (years): } 62 \\
\text { Males (\%): } 66\end{array}$ \\
\hline
\end{tabular}

Interventions

Experimental group: panitumumab + FOLFIRI $(n=91)$

Panitumumab (blocking monoclonal antibody targeting EGFR): $6 \mathrm{mg} / \mathrm{kg}$, i.v., every 2 weeks

Control group: bevacizumab + FOLFIRI $(n=91)$

Bevacizumab (blocking monoclonal antibody targeting VEGF): $5 \mathrm{mg} / \mathrm{kg}$ to $10 \mathrm{mg} / \mathrm{kg}$, i.v., every 2 weeks

Co-intervention: FOLFIRI (i.v., every 2 weeks): irinotecan $\left(180 \mathrm{mg} / \mathrm{m}^{2}\right)+5 \mathrm{FU}\left(2800 \mathrm{mg} / \mathrm{m}^{2}\right)+$ leucovorin $\left(400 \mathrm{mg} / \mathrm{m}^{2}\right)$ 
Hecht 2015 (Continued)
Notes
Country: USA
Dropouts: none reported

\section{Risk of bias}

\begin{tabular}{|c|c|c|}
\hline Bias & Authors' judgement & Support for judgement \\
\hline $\begin{array}{l}\text { Random sequence genera- } \\
\text { tion (selection bias) }\end{array}$ & Unclear risk & Unreported \\
\hline $\begin{array}{l}\text { Allocation concealment } \\
\text { (selection bias) }\end{array}$ & Unclear risk & Unreported \\
\hline $\begin{array}{l}\text { Blinding of participants } \\
\text { and personnel (perfor- } \\
\text { mance bias) } \\
\text { All outcomes }\end{array}$ & High risk & Open-label trial \\
\hline $\begin{array}{l}\text { Blinding of outcome as- } \\
\text { sessment (detection bias) } \\
\text { All outcomes }\end{array}$ & High risk & Open-label trial \\
\hline $\begin{array}{l}\text { Incomplete outcome data } \\
\text { (attrition bias) } \\
\text { Efficacy outcomes }\end{array}$ & Low risk & We found no evidence of attrition bias \\
\hline $\begin{array}{l}\text { Incomplete outcome data } \\
\text { (attrition bias) } \\
\text { Safety and QoL outcomes }\end{array}$ & Low risk & We found no evidence of attrition bias \\
\hline $\begin{array}{l}\text { Selective reporting (re- } \\
\text { porting bias) }\end{array}$ & Low risk & We found no evidence of reporting bias \\
\hline Other bias? & Low risk & We found no evidence of other bias \\
\hline
\end{tabular}

Iwamoto 2015

\begin{tabular}{|c|c|}
\hline Methods & Parallel-group RCT, open-label, multicentre, national \\
\hline Participants & $\begin{array}{l}\text { People with metastatic CRC who did not respond to first-line therapy with FOLFOX + bevacizumab } \\
\text { Mean age (years): } 66 \\
\text { Males (\%): } 56\end{array}$ \\
\hline Interventions & $\begin{array}{l}\text { Experimental group: bevacizumab (low dose) + FOLFIRI }(\mathrm{n}=181) \\
\text { Bevacizumab (blocking monoclonal antibody targeting VEGF) low dose: } 5 \mathrm{mg} / \mathrm{kg} \text { (i.v., every } 2 \text { weeks) } \\
\text { Control group: bevacizumab (high dose) + FOLFIRI ( } \mathrm{n}=188) \\
\text { Bevacizumab (blocking monoclonal antibody targeting VEGF) high dose: } 10 \mathrm{mg} / \mathrm{kg} \text { (i.v., every } 2 \text { weeks) } \\
\text { Co-intervention: FOLFIRI (i.v., every } 2 \text { weeks): irinotecan }\left(150 \mathrm{mg} / \mathrm{m}^{2}\right)+5 \mathrm{FU}\left(2800 \mathrm{mg} / \mathrm{m}^{2}\right)+\text { leucov- } \\
\text { orin }\left(200 \mathrm{mg} / \mathrm{m}^{2} \text { ) }\right.\end{array}$ \\
\hline
\end{tabular}


Iwamoto 2015 (Continued)

\begin{tabular}{ll} 
Outcomes & OS, PFS, ORR, SAE \\
\hline Notes & Country: Japan \\
& Dropouts: 4 (1 in low-dose arm; 3 in high-dose arm)
\end{tabular}

\section{Risk of bias}

\begin{tabular}{|c|c|c|}
\hline Bias & Authors' judgement & Support for judgement \\
\hline $\begin{array}{l}\text { Random sequence genera- } \\
\text { tion (selection bias) }\end{array}$ & Low risk & Dynamic randomization with minimization method \\
\hline $\begin{array}{l}\text { Allocation concealment } \\
\text { (selection bias) }\end{array}$ & Low risk & Centralized randomization \\
\hline $\begin{array}{l}\text { Blinding of participants } \\
\text { and personnel (perfor- } \\
\text { mance bias) } \\
\text { All outcomes }\end{array}$ & High risk & Open-label trial \\
\hline $\begin{array}{l}\text { Blinding of outcome as- } \\
\text { sessment (detection bias) } \\
\text { All outcomes }\end{array}$ & High risk & Open-label trial \\
\hline $\begin{array}{l}\text { Incomplete outcome data } \\
\text { (attrition bias) } \\
\text { Efficacy outcomes }\end{array}$ & Low risk & We found no evidence of attrition bias \\
\hline $\begin{array}{l}\text { Incomplete outcome data } \\
\text { (attrition bias) } \\
\text { Safety and QoL outcomes }\end{array}$ & Low risk & We found no evidence of attrition bias \\
\hline $\begin{array}{l}\text { Selective reporting (re- } \\
\text { porting bias) }\end{array}$ & Low risk & We found no evidence of reporting bias \\
\hline Other bias? & Low risk & We found no evidence of other bias \\
\hline
\end{tabular}

Kim 2009

\begin{tabular}{ll}
\hline Methods & Parallel-group RCT, open-label, multicentre, national \\
\hline Participants & People with metastatic CRC who did not respond to first-line therapy with 5FU \\
& Mean age (years): 63 \\
& Males (\%): 62 \\
\hline
\end{tabular}

Interventions $\quad$ Experimental group: FOLFOX4 $(n=246)$

FOLFOX4 (i.v., every 2 weeks): oxaliplatin $\left(85 \mathrm{mg} / \mathrm{m}^{2}\right)+5 F U\left(1000 \mathrm{mg} / \mathrm{m}^{2}\right)+$ leucovorin $\left(200 \mathrm{mg} / \mathrm{m}^{2}\right)$

Control group: irinotecan $(n=245)$

Irinotecan: $350 \mathrm{mg} / \mathrm{m}^{2}$, i.v., every 3 weeks 
Kim 2009 (Continued)

\begin{tabular}{ll} 
Outcomes & OS, PFS, ORR, SAE \\
\hline Notes & Country: USA \\
& Dropouts: 6 (3 per arm)
\end{tabular}

\section{Risk of bias}

\begin{tabular}{|c|c|c|}
\hline Bias & Authors' judgement & Support for judgement \\
\hline $\begin{array}{l}\text { Random sequence genera- } \\
\text { tion (selection bias) }\end{array}$ & Low risk & $\begin{array}{l}\text { "Patients were randomly assigned to treatment through dynamic allocation } \\
\text { designed to balance assignment for stratification factors" }\end{array}$ \\
\hline $\begin{array}{l}\text { Allocation concealment } \\
\text { (selection bias) }\end{array}$ & Low risk & Remote registration and randomization through a website or by telephone \\
\hline $\begin{array}{l}\text { Blinding of participants } \\
\text { and personnel (perfor- } \\
\text { mance bias) } \\
\text { All outcomes }\end{array}$ & High risk & Open-label trial \\
\hline $\begin{array}{l}\text { Blinding of outcome as- } \\
\text { sessment (detection bias) } \\
\text { All outcomes }\end{array}$ & High risk & Open-label trial \\
\hline $\begin{array}{l}\text { Incomplete outcome data } \\
\text { (attrition bias) } \\
\text { Efficacy outcomes }\end{array}$ & Low risk & We found no evidence of attrition bias \\
\hline $\begin{array}{l}\text { Incomplete outcome data } \\
\text { (attrition bias) } \\
\text { Safety and QoL outcomes }\end{array}$ & Low risk & We found no evidence of attrition bias \\
\hline $\begin{array}{l}\text { Selective reporting (re- } \\
\text { porting bias) }\end{array}$ & Low risk & We found no evidence of reporting bias \\
\hline Other bias? & Low risk & We found no evidence of other bias \\
\hline
\end{tabular}

Liu 2015

\begin{tabular}{ll}
\hline Methods & Parallel-group RCT, open label, single centre \\
\hline Participants & $\begin{array}{l}\text { People with metastatic CRC who did not respond to first-line therapy with 5FU- or oxaliplatin-based } \\
\text { regimen } \\
\text { Mean age (years): } 62 \\
\text { Males (\%): } 61\end{array}$ \\
\hline
\end{tabular}

FOLFIRI: (i.v., every 2 weeks): irinotecan $\left(180 \mathrm{mg} / \mathrm{m}^{2}\right)+5 F U\left(2800 \mathrm{mg} / \mathrm{m}^{2}\right)+$ leucovorin $\left(400 \mathrm{mg} / \mathrm{m}^{2}\right)$ 
Liu 2015 (Continued)

\section{Control group: FOLFIRI $(\mathrm{n}=77)$}

FOLFIRI: (i.v., every 2 weeks): irinotecan $\left(180 \mathrm{mg} / \mathrm{m}^{2}\right)+5 \mathrm{FU}\left(2800 \mathrm{mg} / \mathrm{m}^{2}\right)+$ leucovorin $\left(400 \mathrm{mg} / \mathrm{m}^{2}\right)$

\begin{tabular}{ll}
\hline Outcomes & OS, PFS, ORR, SAE \\
\hline Notes & Country: China \\
& $\begin{array}{l}\text { Quality issue: outcome findings (effect size + confidence intervals) do not appear to coincide with Ka- } \\
\text { plan-Meier curves findings } \\
\text { Dropouts: none reported }\end{array}$
\end{tabular}

\section{Risk of bias}

\begin{tabular}{|c|c|c|}
\hline Bias & Authors' judgement & Support for judgement \\
\hline $\begin{array}{l}\text { Random sequence genera- } \\
\text { tion (selection bias) }\end{array}$ & Unclear risk & Unreported \\
\hline $\begin{array}{l}\text { Allocation concealment } \\
\text { (selection bias) }\end{array}$ & Unclear risk & Unreported \\
\hline $\begin{array}{l}\text { Blinding of participants } \\
\text { and personnel (perfor- } \\
\text { mance bias) } \\
\text { All outcomes }\end{array}$ & High risk & Open-label trial \\
\hline $\begin{array}{l}\text { Blinding of outcome as- } \\
\text { sessment (detection bias) } \\
\text { All outcomes }\end{array}$ & High risk & Open-label trial \\
\hline $\begin{array}{l}\text { Incomplete outcome data } \\
\text { (attrition bias) } \\
\text { Efficacy outcomes }\end{array}$ & Low risk & We found no evidence of attrition bias \\
\hline $\begin{array}{l}\text { Incomplete outcome data } \\
\text { (attrition bias) } \\
\text { Safety and QoL outcomes }\end{array}$ & Low risk & We found no evidence of attrition bias \\
\hline $\begin{array}{l}\text { Selective reporting (re- } \\
\text { porting bias) }\end{array}$ & Low risk & We found no evidence of reporting bias \\
\hline Other bias? & Low risk & We found no evidence of other bias \\
\hline
\end{tabular}

\section{Masi 2015}

\begin{tabular}{ll}
\hline Methods & Parallel-group RCT, open label, multicentre, national \\
\hline Participants & $\begin{array}{l}\text { People with metastatic CRC who did not respond to first-line therapy with bevacizumab-containing } \\
\text { regimen }\end{array}$ \\
& Mean age (years): 64 \\
& Males (\%): 60
\end{tabular}

Experimental group: bevacizumab + chemotherapy (FOLFOX or FOLFIRI) ( $n=92)$ 
Masi 2015 (Continued)

Bevacizumab (blocking monoclonal antibody targeting VEGF): schedule unreported

Chemotherapy: FOLFOX or FOLFIRI (based on first-line regimen)

Control group: chemotherapy (FOLFOX or FOLFIRI) ( $n=92)$

Chemotherapy: FOLFOX or FOLFIRI (based on first-line regimen)

\begin{tabular}{ll}
\hline Outcomes & OS, PFS, ORR, SAE \\
\hline Notes & Country: Italy \\
& Dropouts: none reported \\
\hline
\end{tabular}

\section{Risk of bias}

\begin{tabular}{|c|c|c|}
\hline Bias & Authors' judgement & Support for judgement \\
\hline $\begin{array}{l}\text { Random sequence genera- } \\
\text { tion (selection bias) }\end{array}$ & Unclear risk & Unreported \\
\hline $\begin{array}{l}\text { Allocation concealment } \\
\text { (selection bias) }\end{array}$ & Unclear risk & Unreported \\
\hline $\begin{array}{l}\text { Blinding of participants } \\
\text { and personnel (perfor- } \\
\text { mance bias) } \\
\text { All outcomes }\end{array}$ & High risk & Open-label trial \\
\hline $\begin{array}{l}\text { Blinding of outcome as- } \\
\text { sessment (detection bias) } \\
\text { All outcomes }\end{array}$ & High risk & Open-label trial \\
\hline $\begin{array}{l}\text { Incomplete outcome data } \\
\text { (attrition bias) } \\
\text { Efficacy outcomes }\end{array}$ & Low risk & We found no evidence of attrition bias \\
\hline $\begin{array}{l}\text { Incomplete outcome data } \\
\text { (attrition bias) } \\
\text { Safety and QoL outcomes }\end{array}$ & Low risk & We found no evidence of attrition bias \\
\hline $\begin{array}{l}\text { Selective reporting (re- } \\
\text { porting bias) }\end{array}$ & Low risk & We found no evidence of reporting bias \\
\hline Other bias? & Low risk & We found no evidence of other bias \\
\hline
\end{tabular}

\section{Muro 2010}

\begin{tabular}{ll}
\hline Methods & Parallel-group RCT, open label, multicentre, national \\
\hline Participants & People with metastatic CRC who did not respond to first-line therapy without irinotecan \\
& Mean age (years): 61 \\
& Males (\%): 54
\end{tabular}

Interventions

Experimental group: IRIS (S-1 + irinotecan) $(n=213)$ 
Muro 2010 (Continued)

IRIS: irinotecan ( $125 \mathrm{mg} / \mathrm{m}^{2}$ every 14 days, i.v.) + S-1 (40 mg to $60 \mathrm{mg}$ twice daily for 2 weeks from days 1 to 14 and then a 2-week pause; orally); S-1 is an oral fluoropyrimidine consisting of tegafur, 5 chloro-2,4-dihydroxypyridine (CDHP) and potassium oxonate, in which tegafur is a prodrug of fluorouracil

Control group: FOLFIRI $(n=213)$

FOLFIRI (i.v., every 2 weeks): irinotecan $\left(150 \mathrm{mg} / \mathrm{m}^{2}\right)+5 F U\left(2800 \mathrm{mg} / \mathrm{m}^{2}\right)+$ leucovorin $\left(200 \mathrm{mg} / \mathrm{m}^{2}\right)$

\begin{tabular}{ll}
\hline Outcomes & OS, PFS, ORR, SAE \\
\hline Notes & Country: Japan \\
& Trial acronym: FIRIS \\
& Dropouts: none reported
\end{tabular}

\section{Risk of bias}

\begin{tabular}{|c|c|c|}
\hline Bias & Authors' judgement & Support for judgement \\
\hline $\begin{array}{l}\text { Random sequence genera- } \\
\text { tion (selection bias) }\end{array}$ & Low risk & "Randomisation by a computer program, by use of a minimisation method" \\
\hline $\begin{array}{l}\text { Allocation concealment } \\
\text { (selection bias) }\end{array}$ & Low risk & $\begin{array}{l}\text { "Investigators provided the patient's details to the central registration centre } \\
\text { through a web-based registration system. After an eligibility check, patients } \\
\text { were randomly assigned to receive FOLFIRI or IRIS at the central. Assignment } \\
\text { of patients was concealed from the investigator" }\end{array}$ \\
\hline $\begin{array}{l}\text { Blinding of participants } \\
\text { and personnel (perfor- } \\
\text { mance bias) } \\
\text { All outcomes }\end{array}$ & High risk & Open-label trial \\
\hline $\begin{array}{l}\text { Blinding of outcome as- } \\
\text { sessment (detection bias) } \\
\text { All outcomes }\end{array}$ & High risk & Open-label trial \\
\hline $\begin{array}{l}\text { Incomplete outcome data } \\
\text { (attrition bias) } \\
\text { Efficacy outcomes }\end{array}$ & Low risk & We found no evidence of attrition bias \\
\hline $\begin{array}{l}\text { Incomplete outcome data } \\
\text { (attrition bias) } \\
\text { Safety and QoL outcomes }\end{array}$ & Low risk & We found no evidence of attrition bias \\
\hline $\begin{array}{l}\text { Selective reporting (re- } \\
\text { porting bias) }\end{array}$ & Low risk & We found no evidence of reporting bias \\
\hline Other bias? & Low risk & We found no evidence of other bias \\
\hline
\end{tabular}

\section{O'Neil 2014}

\begin{tabular}{ll}
\hline Methods & Parallel-group RCT (3-arm), open label, multicentre, international \\
\hline Participants & $\begin{array}{l}\text { People with metastatic CRC who did not respond to first-line therapy with irinotecan- or 5FU-contain- } \\
\text { ing regimen }\end{array}$
\end{tabular}


O'Neil 2014 (Continued)

Mean age (years): 60

Males (\%): 51

\begin{tabular}{ll}
\hline Interventions & Experimental group: linifanib low dose + FOLFOX $(\mathrm{n}=49)$ \\
& Linifanib low dose (small molecule tyrosine kinase inhibitor targeting VEGFR and PDGFR): $7.5 \mathrm{mg} / \mathrm{day}$, \\
& oral \\
& Control group: bevacizumab + FOLFOX ( $\mathrm{n}=49)$ \\
& Bevacizumab (blocking monoclonal antibody targeting VEGF): $10 \mathrm{mg} / \mathrm{kg}$ (i.v., every 2 weeks) \\
& $\begin{array}{l}\text { Co-intervention: FOLFOX (i.v., every } 2 \text { weeks): oxaliplatin }\left(85 \mathrm{mg} / \mathrm{m}^{2}\right)+5 \mathrm{FU}\left(2800 \mathrm{mg} / \mathrm{m}^{2}\right)+\text { leucovorin } \\
\left(400 \mathrm{mg} / \mathrm{m}^{2}\right)\end{array}$ \\
\hline Outcomes & OS, PFS, ORR, SAE \\
\hline Notes & Country: international (Western countries) \\
Dropouts: none reported
\end{tabular}

\section{Risk of bias}

\begin{tabular}{lll}
\hline Bias & Authors' judgement & Support for judgement \\
\hline $\begin{array}{l}\text { Random sequence genera- } \\
\text { tion (selection bias) }\end{array}$ & Unclear risk & Unreported \\
\hline $\begin{array}{l}\text { Allocation concealment } \\
\text { (selection bias) }\end{array}$ & Unclear risk & Unreported \\
\hline $\begin{array}{l}\text { Blinding of participants } \\
\text { and personnel (perfor- } \\
\text { mance bias) }\end{array}$ & High risk & Open-label trial \\
All outcomes & & \\
\hline
\end{tabular}

Blinding of outcome as- High risk Open-label trial

sessment (detection bias)

All outcomes

\begin{tabular}{lll}
\hline $\begin{array}{l}\text { Incomplete outcome data } \\
\text { (attrition bias) } \\
\text { Efficacy outcomes }\end{array}$ & Low risk & We found no evidence of attrition bias \\
\hline $\begin{array}{l}\text { Incomplete outcome data } \\
\text { (attrition bias) } \\
\text { Safety and QoL outcomes }\end{array}$ & Low risk & We found no evidence of attrition bias \\
\hline $\begin{array}{l}\text { Selective reporting (re- } \\
\text { porting bias) }\end{array}$ & Low risk & We found no evidence of reporting bias \\
\hline Other bias? & Low risk & We found no evidence of other bias \\
\hline
\end{tabular}

\section{Peeters 2010}

Methods Parallel-group RCT, open label, multicentre, international


Peeters 2010 (Continued)

Participants
People with KRAS wild-type metastatic CRC who did not respond to first-line therapy with 5FU-containing regimen (neither irinotecan nor anti-EGFR drugs allowed)

Mean age (years): 62

Males (\%): 61
Interventions
Experimental group: panitumumab + FOLFIRI $(n=303)$

Panitumumab (blocking monoclonal antibody targeting EGFR): $6 \mathrm{mg} / \mathrm{kg}$ (i.v., every 2 weeks)

FOLFIRI (i.v., every 2 weeks): irinotecan $\left(180 \mathrm{mg} / \mathrm{m}^{2}\right)+5 F U\left(2800 \mathrm{mg} / \mathrm{m}^{2}\right)+$ leucovorin $\left(400 \mathrm{mg} / \mathrm{m}^{2}\right)$

Control group: FOLFIRI $(n=294)$

FOLFIRI (i.v., every 2 weeks): irinotecan $\left(180 \mathrm{mg} / \mathrm{m}^{2}\right)+5 F U\left(2800 \mathrm{mg} / \mathrm{m}^{2}\right)+$ leucovorin $\left(400 \mathrm{mg} / \mathrm{m}^{2}\right)$
OS, PFS, ORR, SAE, QOL

Country: international (Western countries)

Note: the trial originally included also 483 participants with KRAS mutated CRC: since no effect is expected in this population (as the authors acknowledge), only the results from participants with KRAS wild-type CRC are presented here (dropouts: none reported)

\section{Risk of bias}

\begin{tabular}{|c|c|c|}
\hline Bias & Authors' judgement & Support for judgement \\
\hline $\begin{array}{l}\text { Random sequence genera- } \\
\text { tion (selection bias) }\end{array}$ & Unclear risk & Unreported \\
\hline $\begin{array}{l}\text { Allocation concealment } \\
\text { (selection bias) }\end{array}$ & Unclear risk & Unreported \\
\hline $\begin{array}{l}\text { Blinding of participants } \\
\text { and personnel (perfor- } \\
\text { mance bias) } \\
\text { All outcomes }\end{array}$ & High risk & Open-label trial \\
\hline $\begin{array}{l}\text { Blinding of outcome as- } \\
\text { sessment (detection bias) } \\
\text { All outcomes }\end{array}$ & High risk & Open-label trial \\
\hline $\begin{array}{l}\text { Incomplete outcome data } \\
\text { (attrition bias) } \\
\text { Efficacy outcomes }\end{array}$ & Low risk & We found no evidence of attrition bias \\
\hline $\begin{array}{l}\text { Incomplete outcome data } \\
\text { (attrition bias) } \\
\text { Safety and QoL outcomes }\end{array}$ & Low risk & We found no evidence of attrition bias \\
\hline $\begin{array}{l}\text { Selective reporting (re- } \\
\text { porting bias) }\end{array}$ & Low risk & We found no evidence of reporting bias \\
\hline Other bias? & Low risk & We found no evidence of other bias \\
\hline
\end{tabular}


Peeters 2013

\begin{tabular}{ll}
\hline Methods & Parallel-group RCT, double blind, multicentre, international \\
\hline Participants & People with metastatic CRC who did not respond to first-line therapy with FOLFOX regimen \\
& Mean age (years): 56 \\
& Males (\%): 62 \\
\hline Interventions & Experimental group: trebananib + FOLFIRI ( $=95)$ \\
& Trebananib (anti-angiogenic fusion protein targeting the Tie2 receptor): $10 \mathrm{mg} / \mathrm{kg}$, i.v., weekly \\
& Control group: placebo + FOLFIRI ( $\mathrm{n}=49)$ \\
& Co-intervention: FOLFIRI (i.v., every 2 weeks): irinotecan $(180 \mathrm{mg} / \mathrm{kg})+5 \mathrm{FU}(2800 \mathrm{mg} / \mathrm{kg})+$ leucovorin \\
& $(400$ mg/kg) \\
\hline Outcomes & OS, PFS, ORR, SAE \\
\hline Notes & Country: international \\
Dropouts: none reported
\end{tabular}

\section{Risk of bias}

\begin{tabular}{|c|c|c|}
\hline Bias & Authors' judgement & Support for judgement \\
\hline $\begin{array}{l}\text { Random sequence genera- } \\
\text { tion (selection bias) }\end{array}$ & Low risk & Randomization by interactive voice response system \\
\hline $\begin{array}{l}\text { Allocation concealment } \\
\text { (selection bias) }\end{array}$ & Low risk & Randomization by interactive voice response system \\
\hline $\begin{array}{l}\text { Blinding of participants } \\
\text { and personnel (perfor- } \\
\text { mance bias) } \\
\text { All outcomes }\end{array}$ & Low risk & Double-blind trial \\
\hline $\begin{array}{l}\text { Blinding of outcome as- } \\
\text { sessment (detection bias) } \\
\text { All outcomes }\end{array}$ & Unclear risk & Unreported \\
\hline $\begin{array}{l}\text { Incomplete outcome data } \\
\text { (attrition bias) } \\
\text { Efficacy outcomes }\end{array}$ & Low risk & We found no evidence of attrition bias \\
\hline $\begin{array}{l}\text { Incomplete outcome data } \\
\text { (attrition bias) } \\
\text { Safety and QoL outcomes }\end{array}$ & Low risk & We found no evidence of attrition bias \\
\hline $\begin{array}{l}\text { Selective reporting (re- } \\
\text { porting bias) }\end{array}$ & Low risk & We found no evidence of reporting bias \\
\hline Other bias? & Low risk & We found no evidence of other bias \\
\hline
\end{tabular}


Price 2014

\begin{tabular}{ll}
\hline Methods & Parallel-group RCT, open label, multicentre, international \\
\hline Participants & $\begin{array}{l}\text { People with wild-type KRAS metastatic CRC who did not respond to first-line therapy with FOLFOX + be- } \\
\text { vacizumab } \\
\text { Mean age (years): } 61 \\
\text { Males (\%): } 63\end{array}$ \\
\hline
\end{tabular}

Interventions

Experimental group: panitumumab $(n=499)$

Panitumumab (blocking monoclonal antibody targeting EGFR): $6 \mathrm{mg} / \mathrm{kg}$ (i.v., every 2 weeks)

Control group: cetuximab $(n=500)$

Cetuximab (blocking monoclonal antibody targeting EGFR): $400 \mathrm{mg} / \mathrm{kg}$ followed by $250 \mathrm{mg} / \mathrm{kg}$ (i.v., weekly)

Study design: non-inferiority trial

\begin{tabular}{ll}
\hline Outcomes & OS, PFS, ORR, SAE, QoL \\
\hline Notes & Country: international (Western and Eastern countries) \\
& Dropouts: 11 (7 in experimental arm; 4 in control arm) \\
\hline
\end{tabular}

\section{Risk of bias}

\begin{tabular}{|c|c|c|}
\hline Bias & Authors' judgement & Support for judgement \\
\hline $\begin{array}{l}\text { Random sequence genera- } \\
\text { tion (selection bias) }\end{array}$ & Low risk & Randomization by interactive voice response system \\
\hline $\begin{array}{l}\text { Allocation concealment } \\
\text { (selection bias) }\end{array}$ & Low risk & Randomization by interactive voice response system \\
\hline $\begin{array}{l}\text { Blinding of participants } \\
\text { and personnel (perfor- } \\
\text { mance bias) } \\
\text { All outcomes }\end{array}$ & High risk & Open-label trial \\
\hline $\begin{array}{l}\text { Blinding of outcome as- } \\
\text { sessment (detection bias) } \\
\text { All outcomes }\end{array}$ & High risk & Open-label trial \\
\hline $\begin{array}{l}\text { Incomplete outcome data } \\
\text { (attrition bias) } \\
\text { Efficacy outcomes }\end{array}$ & Low risk & We found no evidence of attrition bias \\
\hline $\begin{array}{l}\text { Incomplete outcome data } \\
\text { (attrition bias) } \\
\text { Safety and QoL outcomes }\end{array}$ & Low risk & We found no evidence of attrition bias \\
\hline $\begin{array}{l}\text { Selective reporting (re- } \\
\text { porting bias) }\end{array}$ & Low risk & We found no evidence of reporting bias \\
\hline Other bias? & Low risk & We found no evidence of other bias \\
\hline
\end{tabular}


Rothenberg 2003_folfox

\begin{tabular}{ll}
\hline Methods & Parallel-group RCT (3-arm), open label (?), multicentre, international \\
\hline Participants & People with metastatic CRC who did not respond to first-line therapy with irinotecan-based regimen \\
& Mean age (years): 60 \\
& Males (\%): 58 \\
\hline
\end{tabular}

Interventions $\quad$ Experimental group: FOLFOX $(n=152)$

FOLFOX (i.v., every 2 weeks): oxaliplatin $\left(85 \mathrm{mg} / \mathrm{m}^{2}\right)+5 \mathrm{FU}\left(2000 \mathrm{mg} / \mathrm{m}^{2}\right)+$ leucovorin $\left(400 \mathrm{mg} / \mathrm{m}^{2}\right)$

Control group: $5 \mathrm{FU}(\mathrm{n}=151)$

5FU (i.v., every 2 weeks): $5 F U\left(2000 \mathrm{mg} / \mathrm{m}^{2}\right)+$ leucovorin $\left(400 \mathrm{mg} / \mathrm{m}^{2}\right)$

\begin{tabular}{ll}
\hline Outcomes & PFS, ORR, SAE \\
\hline Notes & Country: international (North America) \\
& Dropouts: 10 (number per arm: unreported) \\
\hline
\end{tabular}

\section{Risk of bias}

\begin{tabular}{|c|c|c|}
\hline Bias & Authors' judgement & Support for judgement \\
\hline $\begin{array}{l}\text { Random sequence genera- } \\
\text { tion (selection bias) }\end{array}$ & Unclear risk & Unreported \\
\hline $\begin{array}{l}\text { Allocation concealment } \\
\text { (selection bias) }\end{array}$ & Low risk & Centralized randomization \\
\hline $\begin{array}{l}\text { Blinding of participants } \\
\text { and personnel (perfor- } \\
\text { mance bias) } \\
\text { All outcomes }\end{array}$ & Unclear risk & Open-label trial (?) \\
\hline $\begin{array}{l}\text { Blinding of outcome as- } \\
\text { sessment (detection bias) } \\
\text { All outcomes }\end{array}$ & Unclear risk & Open-label trial (?) \\
\hline $\begin{array}{l}\text { Incomplete outcome data } \\
\text { (attrition bias) } \\
\text { Efficacy outcomes }\end{array}$ & Low risk & $\begin{array}{l}\text { Intention-to-treat efficacy analysis with } 459 \text { eligible participants out of } 463 \\
\text { randomized participants. Reasons for ineligibility are described for these } 4 \\
\text { participants, but not treatment group assignment }\end{array}$ \\
\hline $\begin{array}{l}\text { Incomplete outcome data } \\
\text { (attrition bias) } \\
\text { Safety and QoL outcomes }\end{array}$ & Low risk & $\begin{array}{l}\text { Safety analysis performed with } 445 \text { participants that received treatment dur- } \\
\text { ing the study out of } 463 \text { randomized participants. Group assignment and rea- } \\
\text { sons for not receiving treatment are not described }\end{array}$ \\
\hline $\begin{array}{l}\text { Selective reporting (re- } \\
\text { porting bias) }\end{array}$ & Unclear risk & OS findings unreported \\
\hline Other bias? & Low risk & We found no evidence of other bias \\
\hline
\end{tabular}


Rothenberg 2003_oxa

\begin{tabular}{ll}
\hline Methods & Parallel-group RCT (3-arm), open label (?), multicentre, international \\
\hline Participants & People with metastatic CRC who did not respond to first-line therapy with irinotecan-based regimen \\
& Mean age (years): 60 \\
& Males (\%): 58
\end{tabular}

\begin{tabular}{ll}
\hline Interventions & Experimental group: oxaliplatin $(\mathrm{n}=156)$ \\
& Oxaliplatin (i.v., every 2 weeks): $85 \mathrm{mg} / \mathrm{m}^{2}$ \\
& Control group: $5 \mathrm{FU}(\mathrm{n}=151)$ \\
& $5 \mathrm{FU}$ (i.v., every 2 weeks): $5 \mathrm{FU}\left(2000 \mathrm{mg} / \mathrm{m}^{2}\right)+$ leucovorin $\left(400 \mathrm{mg} / \mathrm{m}^{2}\right)$ \\
\hline Outcomes & PFS, ORR, SAE \\
\hline Notes & Country: international (North America) \\
& Dropouts: 10 (number per arm: unreported)
\end{tabular}

\section{Risk of bias}

\begin{tabular}{|c|c|c|}
\hline Bias & Authors' judgement & Support for judgement \\
\hline $\begin{array}{l}\text { Random sequence genera- } \\
\text { tion (selection bias) }\end{array}$ & Unclear risk & Unreported \\
\hline $\begin{array}{l}\text { Allocation concealment } \\
\text { (selection bias) }\end{array}$ & Low risk & Centralized randomization \\
\hline $\begin{array}{l}\text { Blinding of participants } \\
\text { and personnel (perfor- } \\
\text { mance bias) } \\
\text { All outcomes }\end{array}$ & Unclear risk & Open-label trial (?) \\
\hline $\begin{array}{l}\text { Blinding of outcome as- } \\
\text { sessment (detection bias) } \\
\text { All outcomes }\end{array}$ & Unclear risk & Open-label trial (?) \\
\hline $\begin{array}{l}\text { Incomplete outcome data } \\
\text { (attrition bias) } \\
\text { Efficacy outcomes }\end{array}$ & Low risk & $\begin{array}{l}\text { Intention-to-treat efficacy analysis with } 459 \text { eligible participants out of } 463 \\
\text { randomized participants. Reasons for ineligibility are described for these } 4 \\
\text { participants, but not treatment group assignment }\end{array}$ \\
\hline $\begin{array}{l}\text { Incomplete outcome data } \\
\text { (attrition bias) } \\
\text { Safety and QoL outcomes }\end{array}$ & Unclear risk & $\begin{array}{l}\text { Safety analysis performed with } 445 \text { participants that received treatment dur- } \\
\text { ing the study out of } 463 \text { randomized participants. Group assignment and rea- } \\
\text { sons for not receiving treatment are not described }\end{array}$ \\
\hline $\begin{array}{l}\text { Selective reporting (re- } \\
\text { porting bias) }\end{array}$ & Unclear risk & OS findings unreported \\
\hline Other bias? & Low risk & We found no evidence of other bias \\
\hline
\end{tabular}


Rothenberg 2008

\begin{tabular}{ll}
\hline Methods & Parallel-group RCT, open label (?), multicentre, international \\
\hline Participants & People with metastatic CRC who did not respond to first-line therapy with irinotecan-based regimen \\
& Mean age (years): 60 \\
& Males (\%): 62 \\
\hline Interventions & Experimental group: XELOX ( $=313)$ \\
& XELOX (every 3 weeks): oxaliplatin $\left(130 \mathrm{mg} / \mathrm{m}^{2}\right.$, i.v. $)+$ capecitabine $\left(1000 \mathrm{mg} / \mathrm{m}^{2}\right.$ twice daily for 15 days) \\
& Control group: FOLFOX ( $=314)$ \\
& FOLFOX (i.v., every 2 weeks): oxaliplatin $\left(85 \mathrm{mg} / \mathrm{m}^{2}\right)+5 \mathrm{FU}\left(2000 \mathrm{mg} / \mathrm{m}^{2}\right)+l$ leucovorin $\left(400 \mathrm{mg} / \mathrm{m}^{2}\right)$ \\
\hline Outcomes & OS, PFS, ORR, SAE \\
\hline Notes & Country: international (Western countries) \\
Study design: non-inferiority trial \\
Dropouts: 8 ( 2 in XELOX arm; 6 in FOLFOX arm)
\end{tabular}

\section{Risk of bias}

\begin{tabular}{|c|c|c|}
\hline Bias & Authors' judgement & Support for judgement \\
\hline $\begin{array}{l}\text { Random sequence genera- } \\
\text { tion (selection bias) }\end{array}$ & Low risk & "Dynamic randomization was used to assign patients to treatment" \\
\hline $\begin{array}{l}\text { Allocation concealment } \\
\text { (selection bias) }\end{array}$ & Unclear risk & Unreported \\
\hline $\begin{array}{l}\text { Blinding of participants } \\
\text { and personnel (perfor- } \\
\text { mance bias) } \\
\text { All outcomes }\end{array}$ & Unclear risk & Open-label trial (?) \\
\hline $\begin{array}{l}\text { Blinding of outcome as- } \\
\text { sessment (detection bias) } \\
\text { All outcomes }\end{array}$ & Unclear risk & $\begin{array}{l}\text { "Assessment of tumor response was made by an independent response review } \\
\text { committee (IRC) that was blinded to treatment assignment" }\end{array}$ \\
\hline $\begin{array}{l}\text { Incomplete outcome data } \\
\text { (attrition bias) } \\
\text { Efficacy outcomes }\end{array}$ & Low risk & We found no evidence of attrition bias \\
\hline $\begin{array}{l}\text { Incomplete outcome data } \\
\text { (attrition bias) } \\
\text { Safety and QoL outcomes }\end{array}$ & Low risk & We found no evidence of attrition bias \\
\hline $\begin{array}{l}\text { Selective reporting (re- } \\
\text { porting bias) }\end{array}$ & Low risk & We found no evidence of reporting bias \\
\hline Other bias? & Low risk & We found no evidence of other bias \\
\hline
\end{tabular}


Rougier 1998

\begin{tabular}{ll}
\hline Methods & Parallel-group RCT, open label (?), multicentre, international \\
\hline Participants & People with metastatic CRC who did not respond to first-line therapy with 5FU-based regimen \\
& Mean age (years): 58 \\
& Males (\%): 60 \\
\hline
\end{tabular}

\begin{tabular}{ll}
\hline Interventions & Experimental group: irinotecan $(\mathrm{n}=134)$ \\
& Irinotecan: $350 \mathrm{mg} / \mathrm{m}^{2}$ (i.v., every 3 weeks) \\
& Control group: $5 \mathrm{FU}(\mathrm{n}=133)$ \\
& $5 \mathrm{FU}$ (i.v., every 2 weeks): $5 \mathrm{FU}\left(2000 \mathrm{mg} / \mathrm{m}^{2}\right)+$ leucovorin $\left(200 \mathrm{mg} / \mathrm{m}^{2}\right)$ \\
\hline Outcomes & OS, PFS, ORR, SAE, QoL \\
\hline Notes & Country: international (Europe) \\
& Dropouts: 10 (5 per arm)
\end{tabular}

\section{Risk of bias}

\begin{tabular}{lll}
\hline Bias & Authors' judgement & Support for judgement \\
\hline $\begin{array}{l}\text { Random sequence genera- } \\
\text { tion (selection bias) }\end{array}$ & Low risk & $\begin{array}{l}\text { "Randomization stratified by centre and performance status was done with a } \\
\text { minimisation procedure" }\end{array}$ \\
\hline $\begin{array}{l}\text { Allocation concealment } \\
\text { (selection bias) }\end{array}$ & Unclear risk & Unreported \\
\hline $\begin{array}{l}\text { Blinding of participants } \\
\text { and personnel (perfor- } \\
\text { mance bias) }\end{array}$ & Unclear risk & Open-label trial (?) \\
All outcomes & & \\
\hline
\end{tabular}

$\begin{array}{lll}\text { Blinding of outcome as- } & \text { Unclear risk } & \text { Open-label trial (?) } \\ \text { sessment (detection bias) } & \end{array}$

All outcomes

$\begin{array}{ll}\begin{array}{l}\text { Incomplete outcome data } \\ \text { (attrition bias) }\end{array} & \text { Low risk } \\ \begin{array}{l}\text { Efficacy outcomes } \\ \text { cle of treatment." The } 11 \text { dropout or withdrawn participants were balanced } \\ \text { among treatment arms with regard to number and reason of exclusion }\end{array} \\ \text { All efficacy results were presented for } 256 \text { participants }\end{array}$

\begin{tabular}{lll}
\hline $\begin{array}{l}\text { Incomplete outcome data } \\
\text { (attrition bias) } \\
\text { Safety and QoL outcomes }\end{array}$ & Low risk & Safety results are presented for 256 participants \\
\hline $\begin{array}{l}\text { Selective reporting (re- } \\
\text { porting bias) }\end{array}$ & Low risk & We found no evidence of reporting bias \\
\hline Other bias? & Low risk & $\begin{array}{l}\text { "A significant difference in baseline was found for the percentage of patients } \\
\text { with hyperleukocytosis, but the mean white-blood-cell counts in both groups } \\
\text { were similar." }\end{array}$
\end{tabular}


Rougier 1998 (Continued)

The review authors considered this imbalance as unimportant and not a source of bias

Scheithauer 2002

\begin{tabular}{ll}
\hline Methods & Parallel-group RCT, open label (?), multicentre, international \\
\hline Participants & People with metastatic CRC who did not respond to first-line therapy with 5FU-based regimen \\
& Mean age (years): 66 \\
Males (\%): 44 \\
\hline
\end{tabular}

Interventions

Experimental group: oxaliplatin + mitomycin $(n=33)$

Oxaliplatin (i.v.): $85 \mathrm{mg} / \mathrm{m}^{2}$ on days $1+15$

Control group: irinotecan + mitomycin $(n=31)$

Irinotecan (i.v.): $120 \mathrm{mg} / \mathrm{m}^{2}$ on days $1+15$

Co-intervention: mitomycin-C (i.v.): $8 \mathrm{mg} / \mathrm{m}^{2}$ every 4 weeks

\begin{tabular}{ll}
\hline Outcomes & ORR, SAE \\
\hline Notes & Country: Austria \\
& Dropouts: none reported \\
\hline
\end{tabular}

\section{Risk of bias}

\begin{tabular}{|c|c|c|}
\hline Bias & Authors' judgement & Support for judgement \\
\hline $\begin{array}{l}\text { Random sequence genera- } \\
\text { tion (selection bias) }\end{array}$ & Low risk & $\begin{array}{l}\text { "Patients were stratified. [...] Balance across strata was attained using the } \\
\text { method of Pocock and Simon" }\end{array}$ \\
\hline $\begin{array}{l}\text { Allocation concealment } \\
\text { (selection bias) }\end{array}$ & Low risk & Centralized randomization \\
\hline $\begin{array}{l}\text { Blinding of participants } \\
\text { and personnel (perfor- } \\
\text { mance bias) } \\
\text { All outcomes }\end{array}$ & Unclear risk & Open-label trial (?) \\
\hline $\begin{array}{l}\text { Blinding of outcome as- } \\
\text { sessment (detection bias) } \\
\text { All outcomes }\end{array}$ & Low risk & Treatment efficacy evaluated by personnel blinded to treatment \\
\hline $\begin{array}{l}\text { Incomplete outcome data } \\
\text { (attrition bias) } \\
\text { Efficacy outcomes }\end{array}$ & Low risk & We found no evidence of attrition bias \\
\hline $\begin{array}{l}\text { Incomplete outcome data } \\
\text { (attrition bias) } \\
\text { Safety and QoL outcomes }\end{array}$ & Low risk & We found no evidence of attrition bias \\
\hline
\end{tabular}


Scheithauer 2002 (Continued)
Selective reporting (re-
Unclear risk
No survival data (hazard ratios or survival curves) reported porting bias)

Other bias? Low risk We found no evidence of other bias

\section{Seymour 2013}

\begin{tabular}{ll}
\hline Methods & Parallel-group RCT, open label, multicentre, national \\
\hline Participants & $\begin{array}{l}\text { People with KRAS wild-type metastatic CRC who did not respond to first-line therapy with 5FU-based } \\
\text { regimen (without oxaliplatin) } \\
\text { Mean age (years): } 64 \\
\text { Males (\%): } 69\end{array}$ \\
\hline
\end{tabular}

Experimental group: irinotecan + panitumumab $(\mathrm{n}=230)$
Irinotecan: $350 \mathrm{mg} / \mathrm{m}^{2}$ (i.v., every 3 weeks)
Panitumumab (blocking monoclonal antibody targeting EGFR): $9 \mathrm{mg} / \mathrm{kg}$ (i.v., every 3 weeks)
Control group: irinotecan $(\mathrm{n}=230)$
Irinotecan: $350 \mathrm{mg} / \mathrm{m}^{2}$ (i.v., every 3 weeks)

\begin{tabular}{ll}
\hline Outcomes & OS, PFS, ORR, SAE, QoL \\
\hline Notes & Country: UK \\
& Dropouts: 12 (6 per arm) \\
\hline
\end{tabular}

\section{Risk of bias}

\begin{tabular}{lll}
\hline Bias & Authors' judgement & Support for judgement \\
\hline $\begin{array}{l}\text { Random sequence genera- } \\
\text { tion (selection bias) }\end{array}$ & Low risk & Computer-generated randomization sequence \\
\hline $\begin{array}{l}\text { Allocation concealment } \\
\text { (selection bias) }\end{array}$ & Low risk & An automated telephonic system was used \\
\hline $\begin{array}{l}\text { Blinding of participants } \\
\text { and personnel (perfor- } \\
\text { mance bias) }\end{array}$ & High risk & Open-label trial \\
All outcomes & \\
\hline $\begin{array}{l}\text { Blinding of outcome as- } \\
\text { sessment (detection bias) } \\
\text { All outcomes }\end{array}$ & High risk & Open-label trial \\
\hline $\begin{array}{l}\text { Incomplete outcome data } \\
\text { (attrition bias) } \\
\text { Efficacy outcomes }\end{array}$ & Low risk & We found no evidence of attrition bias \\
\hline $\begin{array}{l}\text { Incomplete outcome data } \\
\text { (attrition bias) }\end{array}$ & Low risk & We found no evidence of attrition bias \\
\hline
\end{tabular}


Seymour 2013 (Continued)

Safety and QoL outcomes

Selective reporting (re- Low risk We found no evidence of reporting bias porting bias)

Other bias? Low risk We found no evidence of other bias

Shoemaker 2004

\begin{tabular}{ll}
\hline Methods & Parallel-group RCT, open label, multicentre, international \\
\hline Participants & People with metastatic CRC who did not respond to first-line therapy with 5FU-based regimen \\
& Mean age (years): 61 \\
Males (\%): 58
\end{tabular}

Interventions

Experimental group: irinotecan schedule-1 $(n=41)$

Irinotecan schedule-1 (single dose): $350 \mathrm{mg} / \mathrm{m}^{2}$, i.v., every 3 weeks

Control group: irinotecan schedule-2 $(n=44)$

Irinotecan schedule-2 (fractionated): $125 \mathrm{mg} / \mathrm{m}^{2}$, i.v. weekly for 4 weeks every 6 weeks

\begin{tabular}{ll}
\hline Outcomes & ORR, SAE \\
\hline Notes & Country: international (Europe) \\
& Dropouts: 6 (number per arm: unreported)
\end{tabular}

\section{Risk of bias}

\begin{tabular}{|c|c|c|}
\hline Bias & Authors' judgement & Support for judgement \\
\hline $\begin{array}{l}\text { Random sequence genera- } \\
\text { tion (selection bias) }\end{array}$ & Unclear risk & Unreported \\
\hline $\begin{array}{l}\text { Allocation concealment } \\
\text { (selection bias) }\end{array}$ & Low risk & Centralized randomization \\
\hline $\begin{array}{l}\text { Blinding of participants } \\
\text { and personnel (perfor- } \\
\text { mance bias) } \\
\text { All outcomes }\end{array}$ & High risk & Open-label trial \\
\hline $\begin{array}{l}\text { Blinding of outcome as- } \\
\text { sessment (detection bias) } \\
\text { All outcomes }\end{array}$ & High risk & Open-label trial \\
\hline $\begin{array}{l}\text { Incomplete outcome data } \\
\text { (attrition bias) } \\
\text { Efficacy outcomes }\end{array}$ & Unclear risk & $\begin{array}{l}174 \text { participants entered the study. } 168 \text { received medication and comprised } \\
\text { the intention-to-treat population. No information reported on the } 6 \text { partici- } \\
\text { pants who did not receive medication, and to which group they belonged to }\end{array}$ \\
\hline $\begin{array}{l}\text { Incomplete outcome data } \\
\text { (attrition bias) } \\
\text { Safety and QoL outcomes }\end{array}$ & Low risk & We found no evidence of attrition bias \\
\hline
\end{tabular}


Shoemaker 2004 (Continued)

Selective reporting (re- Unclear risk No survival data (hazard ratios or survival curves) reported
porting bias)

Other bias? Low risk We found no evidence of other bias

\section{Sobrero 2008}

\begin{tabular}{ll}
\hline Methods & Parallel-group RCT, open label, multicentre, international \\
\hline Participants & People with metastatic CRC who did not respond to first-line therapy with FOLFOX regimen \\
& Mean age (years): 62 \\
& Males (\%): 63 \\
\hline
\end{tabular}

\begin{tabular}{ll} 
Interventions & Experimental group: irinotecan + cetuximab $(\mathrm{n}=648)$ \\
& Irinotecan: $350 \mathrm{mg} / \mathrm{m}^{2}$ (i.v., every 3 weeks) \\
& Cetuximab (blocking monoclonal antibody targeting EGFR): $400 \mathrm{mg} / \mathrm{m}^{2}$ followed by $250 \mathrm{mg} / \mathrm{m}^{2}$ (i.v., \\
weekly) & Control group: irinotecan ( $\mathrm{n}=650)$ \\
& Irinotecan: $350 \mathrm{mg} / \mathrm{m}^{2}$ (i.v., every 3 weeks) \\
& OS, PFS, ORR, SAE, QoL \\
\hline Outcomes & Country: international (Western countries) \\
People were not selected based on the KRAS status (which is today mandatory for cetuximab adminis- \\
tration because only KRAS wild-type tumours can respond to the drug) \\
Dropouts: none reported
\end{tabular}

\section{Risk of bias}

\begin{tabular}{lll}
\hline Bias & Authors' judgement & Support for judgement \\
\hline $\begin{array}{l}\text { Random sequence genera- } \\
\text { tion (selection bias) }\end{array}$ & Unclear risk & Unreported \\
\hline $\begin{array}{l}\text { Allocation concealment } \\
\text { (selection bias) }\end{array}$ & Unclear risk & Unreported \\
\hline $\begin{array}{l}\text { Blinding of participants } \\
\text { and personnel (perfor- } \\
\text { mance bias) }\end{array}$ & High risk & Open-label trial \\
All outcomes & \\
\hline $\begin{array}{l}\text { Blinding of outcome as- } \\
\text { sessment (detection bias) }\end{array}$ & High risk & \\
All outcomes & & Open-label trial \\
\hline $\begin{array}{l}\text { Incomplete outcome data } \\
\text { (attrition bias) } \\
\text { Efficacy outcomes }\end{array}$ & Low risk & We found no evidence of attrition bias \\
\hline
\end{tabular}


Sobrero 2008 (Continued)

Incomplete outcome data Low risk We found no evidence of attrition bias
(attrition bias)

Safety and QoL outcomes

Selective reporting (re- Low risk $\quad$ We found no evidence of reporting bias
porting bias)

\begin{tabular}{ll}
\hline Other bias? & Low risk $\quad$ We found no evidence of other bias \\
\hline
\end{tabular}

Tabernero 2015

\begin{tabular}{ll}
\hline Methods & Parallel-group RCT, double blind, multicentre, international \\
\hline Participants & People with metastatic CRC who did not respond to first-line therapy with FOLFOX + bevacizumab regi- \\
men & \\
Mean age (years): 62 \\
Males (\%): 57
\end{tabular}

Interventions

Experimental group: ramucirumab + FOLFIRI $(n=536)$

Ramucirumab (blocking monoclonal antibody targeting VEGFR2): $8 \mathrm{mg} / \mathrm{kg}$ (i.v., every 2 weeks)

Control group: placebo + FOLFIRI $(n=536)$

Co-intervention: FOLFIRI (i.v., every 2 weeks): irinotecan $\left(180 \mathrm{mg} / \mathrm{m}^{2}\right)+5 \mathrm{FU}\left(2800 \mathrm{mg} / \mathrm{m}^{2}\right)+$ leucovorin $\left(400 \mathrm{mg} / \mathrm{m}^{2}\right)$

\begin{tabular}{ll}
\hline Outcomes & OS, PFS, ORR, SAE, QoL \\
\hline Notes & Country: international (mainly Western countries) \\
& Dropouts: 15 (8 in experimental and 7 in control arm)
\end{tabular}

\section{Risk of bias}

\begin{tabular}{|c|c|c|}
\hline Bias & Authors' judgement & Support for judgement \\
\hline $\begin{array}{l}\text { Random sequence genera- } \\
\text { tion (selection bias) }\end{array}$ & Low risk & Computerized randomization system \\
\hline $\begin{array}{l}\text { Allocation concealment } \\
\text { (selection bias) }\end{array}$ & Low risk & Randomization by means of a voice response system \\
\hline $\begin{array}{l}\text { Blinding of participants } \\
\text { and personnel (perfor- } \\
\text { mance bias) } \\
\text { All outcomes }\end{array}$ & Low risk & Double-blind trial \\
\hline $\begin{array}{l}\text { Blinding of outcome as- } \\
\text { sessment (detection bias) } \\
\text { All outcomes }\end{array}$ & Unclear risk & Unreported \\
\hline
\end{tabular}

Incomplete outcome data Low risk We found no evidence of attrition bias
(attrition bias)


Tabernero 2015 (Continued)

Efficacy outcomes

Incomplete outcome data Low risk $\quad$ We found no evidence of attrition bias
(attrition bias)

Safety and QoL outcomes

\begin{tabular}{lll}
$\begin{array}{l}\text { Selective reporting (re- } \\
\text { porting bias) }\end{array}$ & Low risk & We found no evidence of reporting bias \\
\hline Other bias? & Low risk & We found no evidence of other bias \\
\hline
\end{tabular}

Tsavaris 2003

\begin{tabular}{ll}
\hline Methods & Parallel-group RCT, open label (?), multicentre, national \\
\hline Participants & People with metastatic CRC who did not respond to first-line therapy with 5FU \\
& Mean age (years): 63 \\
& Males (\%): 56
\end{tabular}

Interventions Experimental group: irinotecan schedule-1 $(n=60)$

Irinotecan schedule-1 (single dose): $350 \mathrm{mg} / \mathrm{m}^{2}$ (i.v. every 3 weeks)

Control group: irinotecan schedule-2 $(n=60)$

Irinotecan schedule-2: (fractionated): $175 \mathrm{mg} / \mathrm{m}^{2}$ (i.v. days 1 and 10 every 3 weeks)

\begin{tabular}{ll}
\hline Outcomes & OS, PFS, ORR, SAE \\
\hline Notes & Country: Greece \\
& Dropouts: none reported \\
\hline
\end{tabular}

\section{Risk of bias}

\begin{tabular}{lll}
\hline Bias & Authors' judgement & Support for judgement \\
\hline $\begin{array}{l}\text { Random sequence genera- } \\
\text { tion (selection bias) }\end{array}$ & Low risk & $\begin{array}{l}\text { "Patients were allocated to the two treatment groups by a simple randomiza- } \\
\text { tion method (closed envelopes)." }\end{array}$ \\
\hline $\begin{array}{l}\text { Allocation concealment } \\
\text { (selection bias) }\end{array}$ & Low risk & $\begin{array}{l}\text { "Patients were allocated to the two treatment groups by a simple randomiza- } \\
\text { tion method (closed envelopes)." }\end{array}$ \\
\hline $\begin{array}{l}\text { Blinding of participants } \\
\begin{array}{l}\text { and personnel (perfor- } \\
\text { mance bias) }\end{array}\end{array}$ & Unclear risk & Open-label trial (?) \\
$\begin{array}{l}\text { All outcomes } \\
\begin{array}{l}\text { Blinding of outcome as- } \\
\text { sessment (detection bias) } \\
\text { All outcomes }\end{array}\end{array}$ & Unclear risk & Open-label trial (?) \\
\hline $\begin{array}{l}\text { Incomplete outcome data } \\
\text { (attrition bias) } \\
\text { Efficacy outcomes }\end{array}$ & Low risk & We found no evidence of attrition bias \\
\hline \hline
\end{tabular}


Tsavaris 2003 (Continued)

Incomplete outcome data Low risk We found no evidence of attrition bias
(attrition bias)

Safety and QoL outcomes

Selective reporting (re- Low risk We found no evidence of reporting bias
porting bias)

\begin{tabular}{ll}
\hline Other bias? $\quad$ Low risk $\quad$ We found no evidence of other bias \\
\hline
\end{tabular}

Van Cutsem 2011

\begin{tabular}{ll}
\hline Methods & Parallel-group RCT, double blind, multicentre, international \\
\hline Participants & People with metastatic CRC who did not respond to first-line therapy with FOLFIRI \\
& Mean age (years): 60 \\
& Males (\%): 58 \\
\hline
\end{tabular}

Interventions $\quad$ Experimental group: FOLFOX + vatalanib $(n=426)$

Vatalanib (also known as PTK787; small molecule tyrosine kinase inhibitor targeting VEGFR): 1250 mg/ day, orally

Control group: FOLFOX + placebo $(n=429)$

Co-intervention: FOLFOX (i.v., every 2 weeks): oxaliplatin $\left(85 \mathrm{mg} / \mathrm{m}^{2}\right)+5 \mathrm{FU}\left(2000 \mathrm{mg} / \mathrm{m}^{2}\right)+$ leucovorin $\left(400 \mathrm{mg} / \mathrm{m}^{2}\right)$

\begin{tabular}{ll}
\hline Outcomes & OS, PFS, SAE \\
\hline Notes & Country: international (Western countries) \\
& Dropouts: none reported \\
\hline
\end{tabular}

\section{Risk of bias}

\begin{tabular}{|c|c|c|}
\hline Bias & Authors' judgement & Support for judgement \\
\hline $\begin{array}{l}\text { Random sequence genera- } \\
\text { tion (selection bias) }\end{array}$ & Low risk & Randomization by means of an interactive voice response system \\
\hline $\begin{array}{l}\text { Allocation concealment } \\
\text { (selection bias) }\end{array}$ & Low risk & Randomization by means of an interactive voice response system \\
\hline $\begin{array}{l}\text { Blinding of participants } \\
\text { and personnel (perfor- } \\
\text { mance bias) } \\
\text { All outcomes }\end{array}$ & Low risk & Double-blind trial \\
\hline $\begin{array}{l}\text { Blinding of outcome as- } \\
\text { sessment (detection bias) } \\
\text { All outcomes }\end{array}$ & Unclear risk & Unreported \\
\hline
\end{tabular}

Incomplete outcome data Low risk $\quad$ We found no evidence of attrition bias
(attrition bias)


Van Cutsem 2011 (Continued)

Efficacy outcomes

Incomplete outcome data Low risk $\quad$ We found no evidence of attrition bias
(attrition bias)

Safety and QoL outcomes

\begin{tabular}{lll}
$\begin{array}{l}\text { Selective reporting (re- } \\
\text { porting bias) }\end{array}$ & Low risk & Response rates unreported \\
\hline Other bias? & Low risk & We found no evidence of other bias \\
\hline
\end{tabular}

\section{Van Cutsem 2012}

\begin{tabular}{ll}
\hline Methods & Parallel-group RCT, double blind, multicentre, international \\
\hline Participants & People with metastatic CRC who did not respond to first-line therapy with oxaliplatin-based regimen \\
& Mean age (years): 60 \\
Males (\%): 63 \\
\hline
\end{tabular}

Interventions $\quad$ Experimental group: FOLFIRI + aflibercept $(n=612)$

Aflibercept (also known as VEGF trap; blocking fusion protein targeting VEGF): 4 mg/kg (i.v., every 2 weeks)

Control group: FOLFIRI + placebo $(n=614)$

Co-intervention: FOLFIRI (i.v., every 2 weeks): irinotecan $\left(180 \mathrm{mg} / \mathrm{m}^{2}\right)+5 \mathrm{FU}\left(2800 \mathrm{mg} / \mathrm{m}^{2}\right)+$ leucovorin $\left(400 \mathrm{mg} / \mathrm{m}^{2}\right)$

\begin{tabular}{ll}
\hline Outcomes & OS, PFS, ORR, SAE \\
\hline Notes & Country: international (mainly Western countries) \\
& Dropouts: none reported \\
\hline
\end{tabular}

\section{Risk of bias}

\begin{tabular}{|c|c|c|}
\hline Bias & Authors' judgement & Support for judgement \\
\hline $\begin{array}{l}\text { Random sequence genera- } \\
\text { tion (selection bias) }\end{array}$ & Low risk & Randomization by means of an interactive voice response system \\
\hline $\begin{array}{l}\text { Allocation concealment } \\
\text { (selection bias) }\end{array}$ & Low risk & Randomization by means of an interactive voice response system \\
\hline $\begin{array}{l}\text { Blinding of participants } \\
\text { and personnel (perfor- } \\
\text { mance bias) } \\
\text { All outcomes }\end{array}$ & Low risk & Double-blind trial \\
\hline $\begin{array}{l}\text { Blinding of outcome as- } \\
\text { sessment (detection bias) } \\
\text { All outcomes }\end{array}$ & Unclear risk & Unreported \\
\hline
\end{tabular}


Van Cutsem 2012 (Continued)

Incomplete outcome data Low risk We found no evidence of attrition bias

(attrition bias)

Efficacy outcomes

\begin{tabular}{lll}
$\begin{array}{l}\text { Incomplete outcome data } \\
\text { (attrition bias) } \\
\text { Safety and QoL outcomes }\end{array}$ & Low risk & We found no evidence of attrition bias \\
\hline $\begin{array}{l}\text { Selective reporting (re- } \\
\text { porting bias) }\end{array}$ & Low risk & We found no evidence of reporting bias
\end{tabular}

Other bias? Low risk We found no evidence of other bias

Viéitez 2011

\begin{tabular}{ll}
\hline Methods & Parallel-group RCT, double blind, multicentre, national \\
\hline Participants & People with metastatic CRC who did not respond to first-line therapy with 5FU-based regimen \\
& Mean age (years): 60 \\
& Males (\%): 58 \\
\hline
\end{tabular}

Interventions

Experimental group: raltitrexed + gefitinib $(n=38)$

Raltitrexed: $3 \mathrm{mg} / \mathrm{m}^{2}$ (i.v., every 3 weeks)

Gefitinib: $250 \mathrm{mg} /$ day (orally)

Control group: raltitrexed $(n=38)$

Raltitrexed: $3 \mathrm{mg} / \mathrm{m}^{2}$ (i.v., every 3 weeks)

\begin{tabular}{ll}
\hline Outcomes & OS, PFS, ORR, SAE \\
\hline Notes & Country: Spain \\
& Dropouts: none reported
\end{tabular}

\section{Risk of bias}

Bias Authors' judgement Support for judgement

Random sequence genera- Unclear risk Unreported
tion (selection bias)

\begin{tabular}{lll}
\hline $\begin{array}{l}\text { Allocation concealment } \\
\text { (selection bias) }\end{array}$ & Unclear risk & Unreported \\
\hline $\begin{array}{l}\text { Blinding of participants } \\
\text { and personnel (perfor- }\end{array}$ & Low risk & Double-blind trial \\
$\begin{array}{l}\text { mance bias) } \\
\text { All outcomes }\end{array}$ & \\
\hline
\end{tabular}

Blinding of outcome as- Unclear risk Unreported
sessment (detection bias)

All outcomes 
Viéitez 2011 (Continued)

Incomplete outcome data Low risk We found no evidence of attrition bias
(attrition bias)

Efficacy outcomes

\begin{tabular}{lll}
\hline $\begin{array}{l}\text { Incomplete outcome data } \\
\text { (attrition bias) } \\
\text { Safety and QoL outcomes }\end{array}$ & Low risk & We found no evidence of attrition bias \\
\hline $\begin{array}{l}\text { Selective reporting (re- } \\
\text { porting bias) }\end{array}$ & Low risk & We found no evidence of reporting bias \\
\hline Other bias? & Low risk & We found no evidence of other bias \\
\hline
\end{tabular}

Élez 2015

\begin{tabular}{ll}
\hline Methods & Parallel-group RCT (3-arm), open label, multicentre, international \\
\hline Participants & $\begin{array}{l}\text { People with KRAS wild-type metastatic CRC who did not respond to first-line therapy with oxali- } \\
\text { platin-containing regimen } \\
\text { Mean age (years): } 60 \\
\text { Males (\%): } 61\end{array}$
\end{tabular}

\begin{tabular}{ll}
\hline Interventions & Experimental group: abituzumab low dose + cetuximab + irinotecan $(\mathrm{n}=73)$ \\
& Abituzumab (blocking monoclonal antibody targeting integrin-alphaV): $500 \mathrm{mg}$ (i.v., every 2 weeks) \\
& Control group: cetuximab + irinotecan $(\mathrm{n}=72)$ \\
& Irinotecan (i.v., every 2 weeks): $180 \mathrm{mg} / \mathrm{m}^{2}$ \\
& Co-intervention: cetuximab (blocking monoclonal antibody targeting EGFR): 400 (first dose) and then \\
& $250 \mathrm{mg} / \mathrm{m}^{2}$ (i.v., weekly) \\
\hline Outcomes & OS, PFS, ORR, SAE \\
\hline Notes & Country: international (Western countries) \\
Dropouts: none reported
\end{tabular}

\section{Risk of bias}

\begin{tabular}{lll}
\hline Bias & Authors' judgement & Support for judgement \\
\hline $\begin{array}{l}\text { Random sequence genera- } \\
\text { tion (selection bias) }\end{array}$ & Unclear risk & Unreported \\
\hline $\begin{array}{l}\text { Allocation concealment } \\
\text { (selection bias) }\end{array}$ & Low risk & Centralized randomization \\
\hline $\begin{array}{l}\text { Blinding of participants } \\
\text { and personnel (perfor- } \\
\text { mance bias) }\end{array}$ & High risk \\
All outcomes & & Open-label trial \\
\hline
\end{tabular}


Élez 2015 (Continued)

Blinding of outcome as-
sessment (detection bias)

All outcomes

\begin{tabular}{lll}
\hline $\begin{array}{l}\text { Incomplete outcome data } \\
\text { (attrition bias) } \\
\text { Efficacy outcomes }\end{array}$ & Low risk & We found no evidence of attrition bias \\
\hline $\begin{array}{l}\text { Incomplete outcome data } \\
\text { (attrition bias) } \\
\text { Safety and QoL outcomes }\end{array}$ & Low risk & We found no evidence of attrition bias \\
\hline $\begin{array}{l}\text { Selective reporting (re- } \\
\text { porting bias) }\end{array}$ & Low risk & We found no evidence of reporting bias \\
\hline \begin{tabular}{l} 
Other bias? \\
\hline
\end{tabular} & Low risk & We found no evidence of other bias \\
\hline
\end{tabular}

5FU: 5-fluorouracil; CRC: colorectal cancer; EGFR: epidermal growth factor receptor; FOLFIRI: 5FU plus leucovorin plus irinotecan; FOLFOX: 5FU plus leucovorin plus oxaliplatin; i.v.: intravenous; $n$ : number of participants; ORR: overall response rate; OS: overall survival; PFS: progression-free survival; QoL: quality of life; RCT: randomized controlled trial; SAE: severe adverse effect; VEGF: vascular endothelial growth factor; XELOX: capecitabine + oxaliplatin.

\section{Characteristics of excluded studies [ordered by study ID]}

\begin{tabular}{|c|c|}
\hline Study & Reason for exclusion \\
\hline Amado 2008 & Third (or higher)-line treatment (on results described in Van Cutsem 2007) \\
\hline Aranda 1998 & First-line treatment \\
\hline Chau 2004 & Subgroup analysis of Lal 2004 trial \\
\hline Chibaudel 2016 & Non-comparative study \\
\hline Comella 2000 & First-line treatment \\
\hline Comella 2002 & First-line treatment \\
\hline Cunningham 2004 & Third (or higher)-line treatment \\
\hline Ducreux 2011 & Comparison of first- to second-line sequence of regimens \\
\hline Garrett 2013 & Third (or higher)-line treatment \\
\hline Grothey 2013 & Third (or higher)-line treatment \\
\hline Hendlisz 2010 & Hepatic arterial infusion \\
\hline Hurwitz 2004 & First-line treatment \\
\hline Jonker 2007 & Third (or higher)-line treatment \\
\hline Kabbinavar 2003 & First-line treatment \\
\hline Kemeny 1993 & Hepatic arterial infusion \\
\hline
\end{tabular}




\begin{tabular}{|c|c|}
\hline Study & Reason for exclusion \\
\hline Koopman 2007 & Comparison of first- to second-line sequence of regimens \\
\hline Labianca 2011 & First-line treatment (continuous vs intermittent) \\
\hline Lacouture 2010 & Trial focusing on skin toxicity \\
\hline Lal 2004 & Only participants responding to second-line therapy were randomized to 2 different treatments \\
\hline Levi 1997 & First-line treatment \\
\hline Lin 2014 & Third (or higher)-line treatment \\
\hline Mandalá 2009 & First-line treatment \\
\hline Maughan 2003 & Only participants responding (or stable) after first-line treatment \\
\hline Mayer 2015 & Third (or higher)-line treatment \\
\hline Muro 2016 & No suitable data (abstract only) \\
\hline Rao 2004 & Third (or higher)-line treatment \\
\hline Reidy 2010 & Third (or higher)-line treatment \\
\hline Rougier 2002 & Third (or higher)-line treatment; no survival data \\
\hline Saltz 2000 & First-line treatment \\
\hline Saltz 2007 & Third (or higher)-line treatment \\
\hline Seymour 2007 & Comparison of first- to second-line sequence of regimens \\
\hline Siu 2013 & Third (or higher)-line treatment \\
\hline Tournigand 2004 & Comparison of first- to second-line sequence of regimens \\
\hline Tournigand 2006 & First-line treatment (continuous vs intermittent) \\
\hline Tsavaris 2007 & First-line treatment \\
\hline Van Cutsem 2005 & $\begin{array}{l}\text { Comparison of standard dose irinotecan }\left(350 \mathrm{mg} / \mathrm{m}^{2} \text { ) with a variable dosage ( } 250 \text { or } 350 \text { or } 500\right. \\
\mathrm{mg} / \mathrm{m}^{2} \text { ) according to participant tolerance }\end{array}$ \\
\hline Van Cutsem 2007 & Third (or higher)-line treatment \\
\hline Van Cutsem 2012_bis & $\begin{array}{l}\text { Randomization of a subgroup of participants (those with low toxicity after cetuximab administra- } \\
\text { tion) }\end{array}$ \\
\hline Van Cutsem 2014 & Third (or higher)-line treatment (most participants) \\
\hline Yasui 2015 & Duplicate of Muro 2010 \\
\hline Yoshino 2012 & Third (or higher)-line treatment \\
\hline
\end{tabular}




\section{DATA AND ANALYSES}

\section{Comparison 1. All}

\begin{tabular}{|c|c|c|c|c|}
\hline Outcome or subgroup title & No. of studies & $\begin{array}{l}\text { No. of partici- } \\
\text { pants }\end{array}$ & Statistical method & Effect size \\
\hline $\begin{array}{l}1 \text { Overall survival (OS)_modern } \\
\text { chemotherapy (CTX) vs } 5 \text {-fluo- } \\
\text { rouracil ( } 5 \mathrm{FU})\end{array}$ & 1 & & Hazard Ratio (Random, 95\% Cl) & $0.69[0.51,0.94]$ \\
\hline $\begin{array}{l}2 \text { Progression-free survival } \\
\text { (PFS)_modern CTX vs 5FU }\end{array}$ & 3 & & Hazard Ratio (Fixed, 95\% Cl) & $0.84[0.73,0.96]$ \\
\hline 2.1 FOLFOX irinotecan (irino) & 2 & & Hazard Ratio (Fixed, 95\% Cl) & $0.59[0.49,0.73]$ \\
\hline 2.2 Oxaliplatin & 1 & & Hazard Ratio (Fixed, 95\% Cl) & $1.11[0.93,1.33]$ \\
\hline $\begin{array}{l}3 \text { Overall response rate (OR- } \\
\text { R)_modern CTX vs } 5 F U\end{array}$ & 3 & 866 & Risk Ratio (IV, Fixed, 95\% CI) & $2.96[1.66,5.27]$ \\
\hline $\begin{array}{l}4 \text { Serious adverse events } \\
\text { (SAE)_modern CTX vs 5FU }\end{array}$ & 3 & 843 & Risk Ratio (IV, Fixed, 95\% CI) & $1.39[1.22,1.58]$ \\
\hline $\begin{array}{l}5 \text { OS_irino combination (com- } \\
\text { bo) }\end{array}$ & 6 & & Hazard Ratio (Random, 95\% Cl) & $0.91[0.79,1.04]$ \\
\hline 6 PFS_irino combo & 6 & & Hazard Ratio (Random, 95\% Cl) & $0.68[0.60,0.76]$ \\
\hline 7 ORR_irino combo & 6 & 2577 & Risk Ratio (IV, Random, 95\% CI) & $2.87[2.10,3.93]$ \\
\hline 8 SAE_irino combo & 6 & 2510 & Risk Ratio (IV, Random, 95\% CI) & $1.18[0.96,1.45]$ \\
\hline $\begin{array}{l}9 \text { OS_bevacizumab (beva) com- } \\
\text { bo }\end{array}$ & 4 & & Hazard Ratio (Random, 95\% Cl) & $0.79[0.70,0.88]$ \\
\hline 10 PFS_beva combo & 4 & & Hazard Ratio (Random, 95\% Cl) & $0.67[0.60,0.75]$ \\
\hline 11 ORR_beva combo & 4 & 1714 & Risk Ratio (IV, Random, 95\% CI) & $1.72[1.23,2.43]$ \\
\hline 12 SAE_beva combo & 4 & 1708 & Risk Ratio (IV, Random, 95\% Cl) & $1.07[0.93,1.25]$ \\
\hline 13 OS_FOLFIRI targeted & 7 & & Hazard Ratio (Random, 95\% Cl) & $0.84[0.77,0.91]$ \\
\hline 14 PFS_FOLFIRI targeted & 7 & & Hazard Ratio (Random, 95\% Cl) & $0.78[0.71,0.87]$ \\
\hline 15 ORR_FOLFIRI targeted & 7 & 3192 & Risk Ratio (IV, Random, 95\% CI) & $2.07[1.31,3.28]$ \\
\hline 16 SAE_FOLFIRI targeted & 7 & 3341 & Risk Ratio (IV, Random, 95\% CI) & $1.30[1.17,1.45]$ \\
\hline 17 OS_FOLFOX targeted & 2 & & Hazard Ratio (Fixed, 95\% Cl) & $0.92[0.82,1.04]$ \\
\hline 18 PFS_FOLFOX targeted & 2 & & Hazard Ratio (Fixed, 95\% Cl) & $0.76[0.66,0.86]$ \\
\hline 19 ORR_FOLFOX targeted & 1 & 578 & Risk Ratio (IV, Random, 95\% CI) & $2.64[1.71,4.06]$ \\
\hline
\end{tabular}




\begin{tabular}{|c|c|c|c|c|}
\hline Outcome or subgroup title & No. of studies & $\begin{array}{l}\text { No. of partici- } \\
\text { pants }\end{array}$ & Statistical method & Effect size \\
\hline 20 SAE_FOLFOX targeted & 2 & 1414 & Risk Ratio (IV, Fixed, 95\% CI) & $1.20[1.13,1.28]$ \\
\hline 21 OS_irino fraction & 2 & & Hazard Ratio (Fixed, 95\% Cl) & $0.86[0.71,1.05]$ \\
\hline 22 PFS_irino fraction & 2 & & Hazard Ratio (Fixed, 95\% Cl) & $0.90[0.71,1.14]$ \\
\hline 23 ORR_irino fraction & 2 & 205 & Risk Ratio (IV, Fixed, 95\% CI) & $0.83[0.45,1.53]$ \\
\hline $24 \mathrm{SAE}$ _irino fraction & 3 & 489 & Risk Ratio (IV, Fixed, 95\% CI) & $0.97[0.87,1.10]$ \\
\hline $\begin{array}{l}25 \text { OS_FOLFIRI + beva vs other } \\
\text { targeted }\end{array}$ & 2 & & Hazard Ratio (Fixed, 95\% Cl) & $1.15[0.86,1.53]$ \\
\hline $\begin{array}{l}26 \text { PFS_FOLFIRI + beva vs other } \\
\text { targeted }\end{array}$ & 2 & & Hazard Ratio (Fixed, 95\% Cl) & $1.10[0.81,1.50]$ \\
\hline $\begin{array}{l}27 \text { ORR_FOLFIRI + beva vs other } \\
\text { targeted }\end{array}$ & 2 & 267 & Risk Ratio (IV, Fixed, 95\% CI) & $1.43[0.94,2.19]$ \\
\hline $\begin{array}{l}28 \text { SAE_FOLFIRI + beva vs other } \\
\text { targeted }\end{array}$ & 2 & 279 & Risk Ratio (IV, Fixed, 95\% CI) & $1.53[1.10,2.11]$ \\
\hline $\begin{array}{l}29 \text { OS_FOLFOX + beva vs other } \\
\text { targeted }\end{array}$ & 2 & & Hazard Ratio (Fixed, 95\% Cl) & $1.14[0.81,1.61]$ \\
\hline $\begin{array}{l}30 \text { PFS_FOLFOX + beva vs other } \\
\text { targeted }\end{array}$ & 2 & & Hazard Ratio (Fixed, 95\% Cl) & $1.26[0.83,1.91]$ \\
\hline $\begin{array}{l}31 \text { ORR_FOLFOX + beva vs other } \\
\text { targeted }\end{array}$ & 2 & 170 & Risk Ratio (IV, Fixed, 95\% CI) & $0.77[0.46,1.29]$ \\
\hline $\begin{array}{l}32 \text { SAE_FOLFOX + beva vs other } \\
\text { targeted }\end{array}$ & 2 & 169 & Risk Ratio (IV, Fixed, 95\% CI) & $1.27[1.03,1.55]$ \\
\hline
\end{tabular}

Analysis 1.1. Comparison 1 All, Outcome 1 Overall survival

(OS)_modern chemotherapy (CTX) vs 5-fluorouracil (5FU).

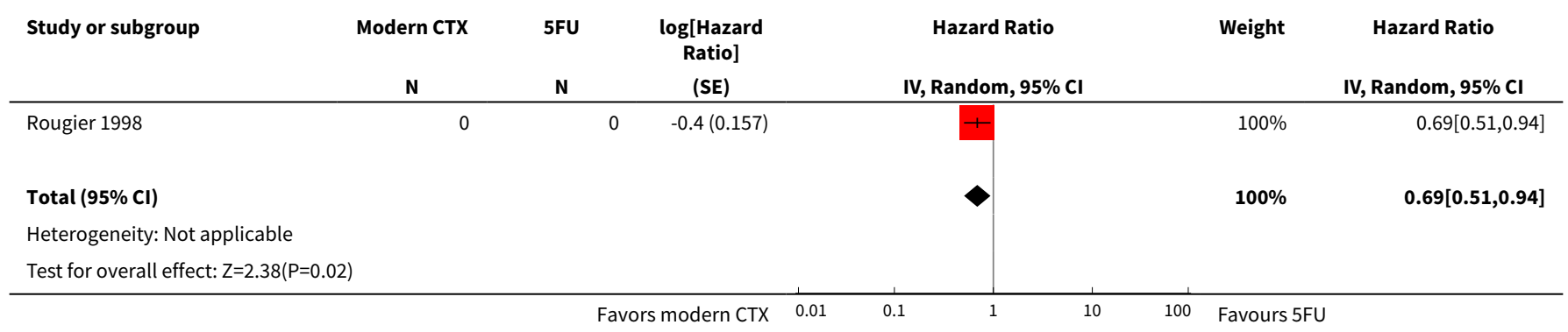


Analysis 1.2. Comparison 1 All, Outcome 2 Progression-free survival (PFS)_modern CTX vs 5FU.

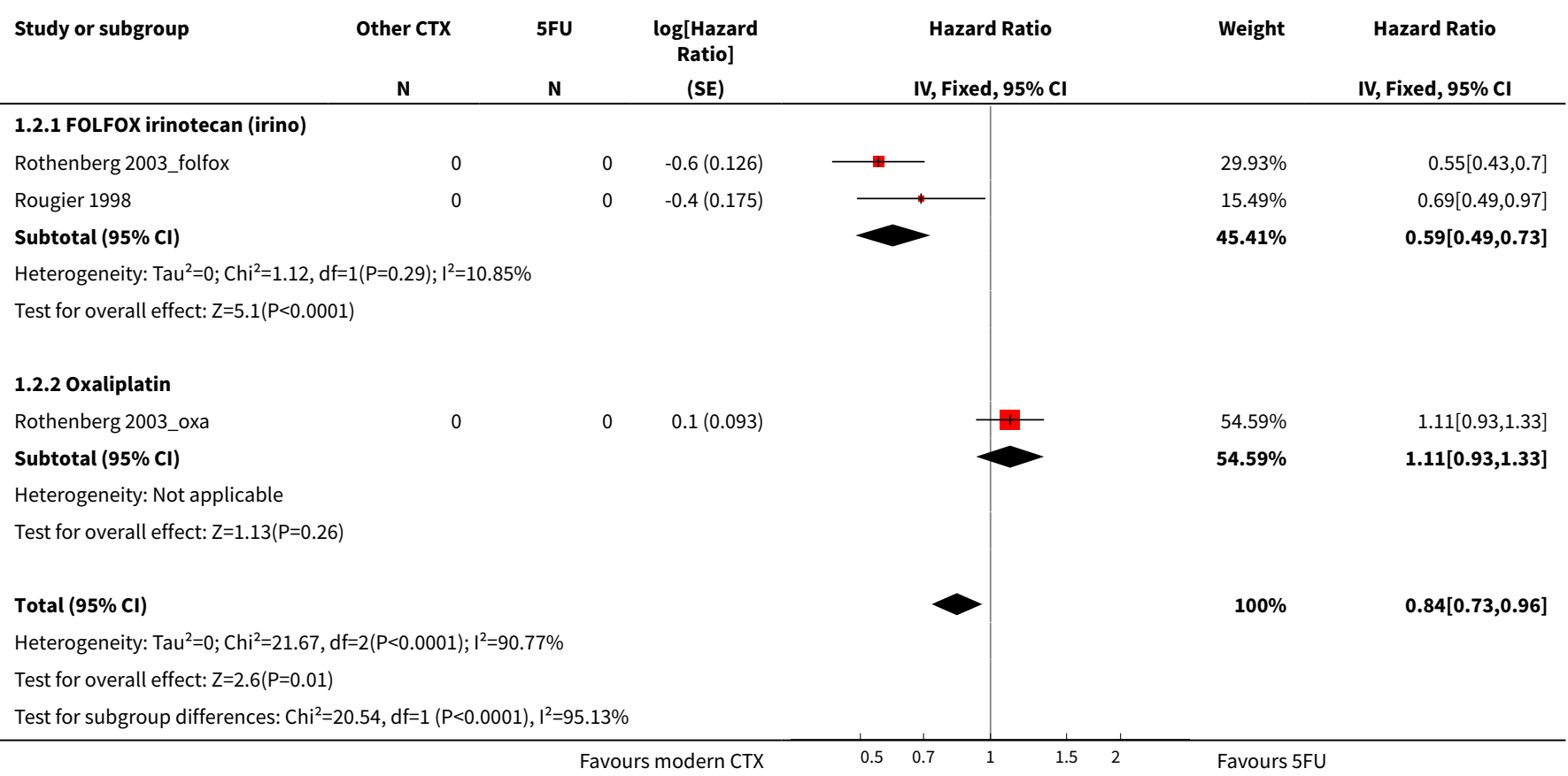

Analysis 1.3. Comparison 1 All, Outcome 3 Overall response rate (ORR)_modern CTX vs 5FU.

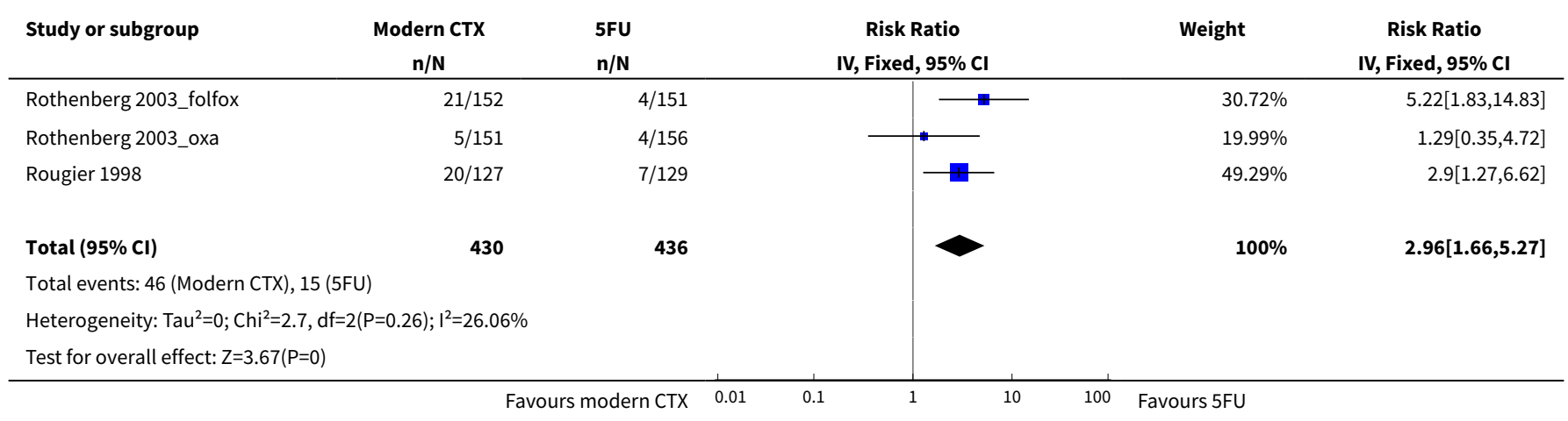

Analysis 1.4. Comparison 1 All, Outcome 4 Serious adverse events (SAE)_modern CTX vs 5FU.

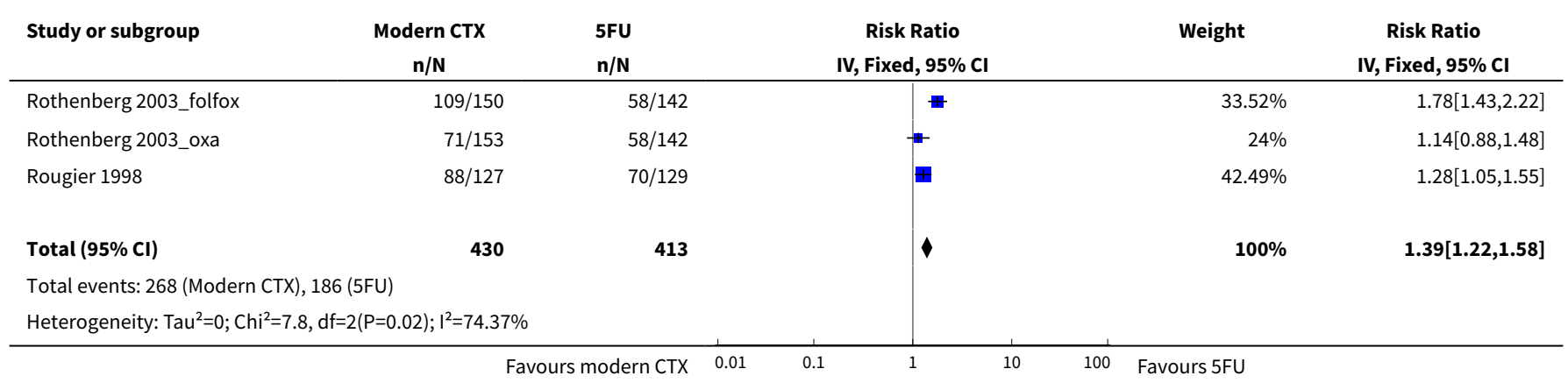




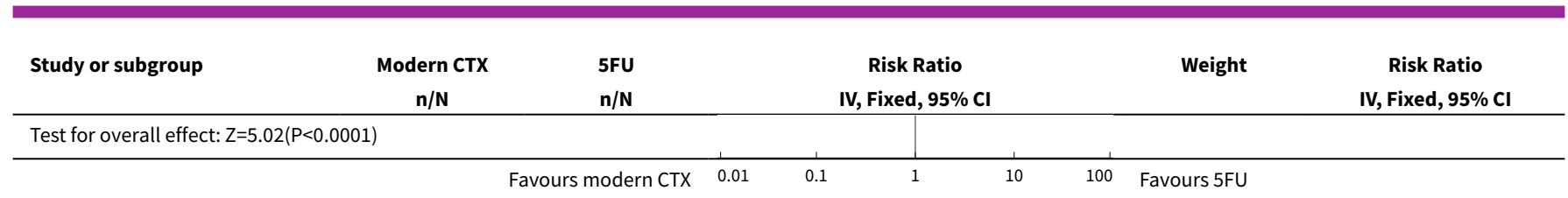

Analysis 1.5. Comparison 1 All, Outcome 5 OS_irino combination (combo).

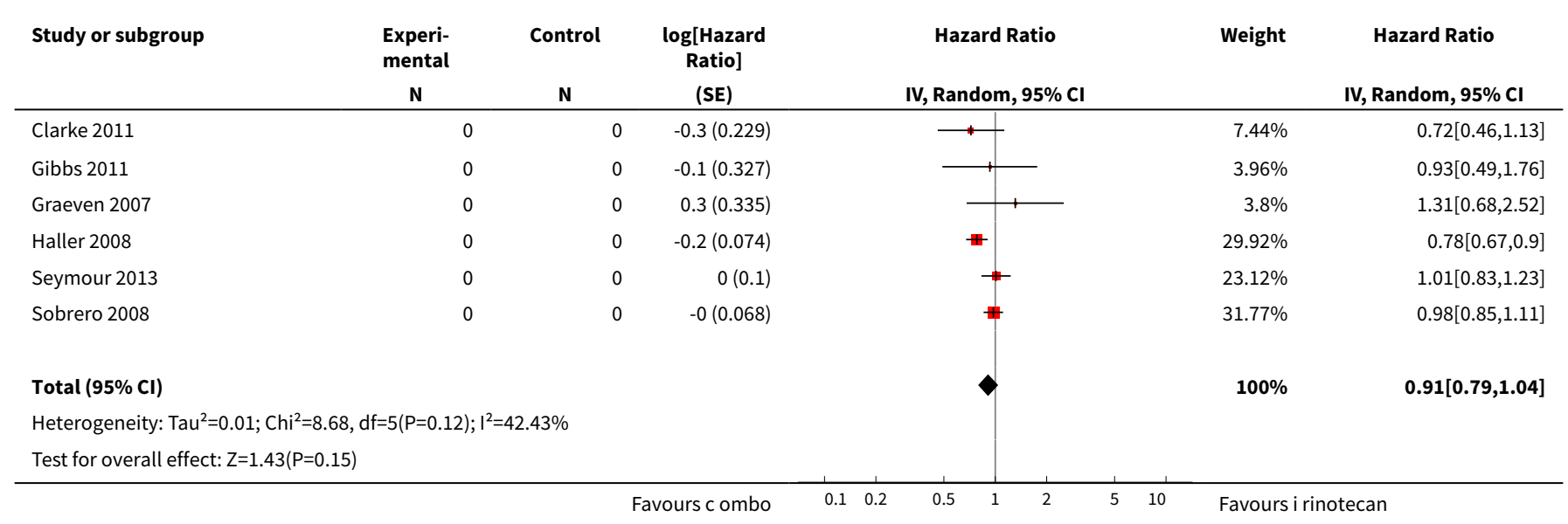

Analysis 1.6. Comparison 1 All, Outcome 6 PFS_irino combo.

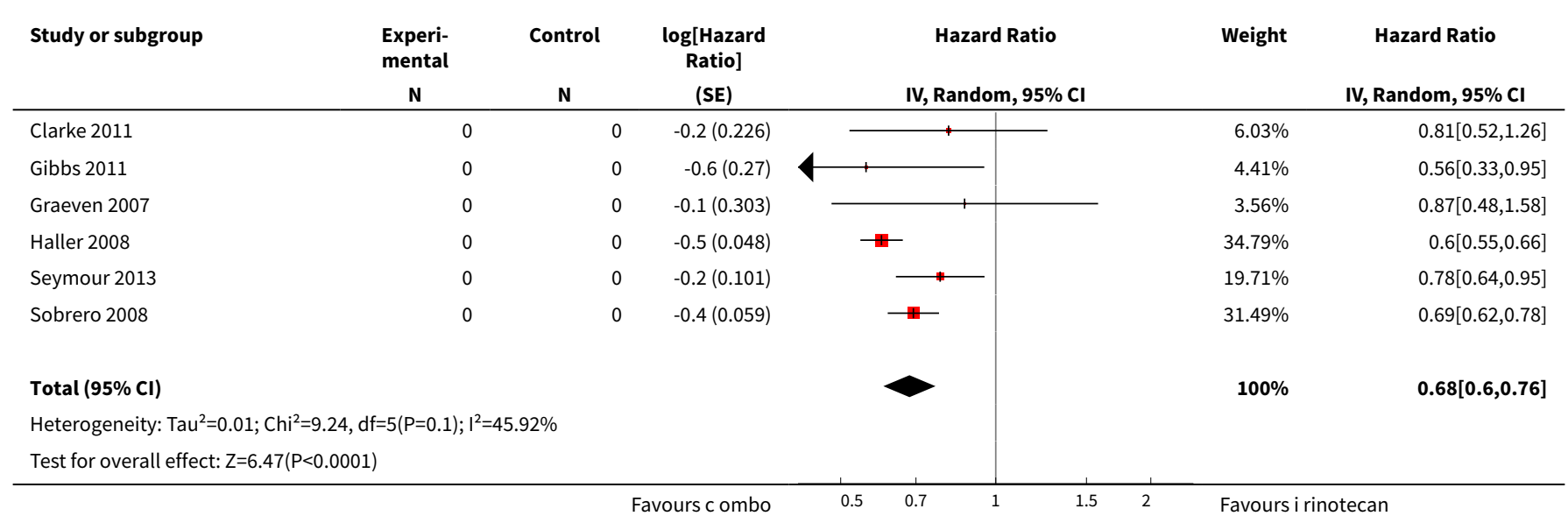

Analysis 1.7. Comparison 1 All, Outcome 7 ORR_irino combo.

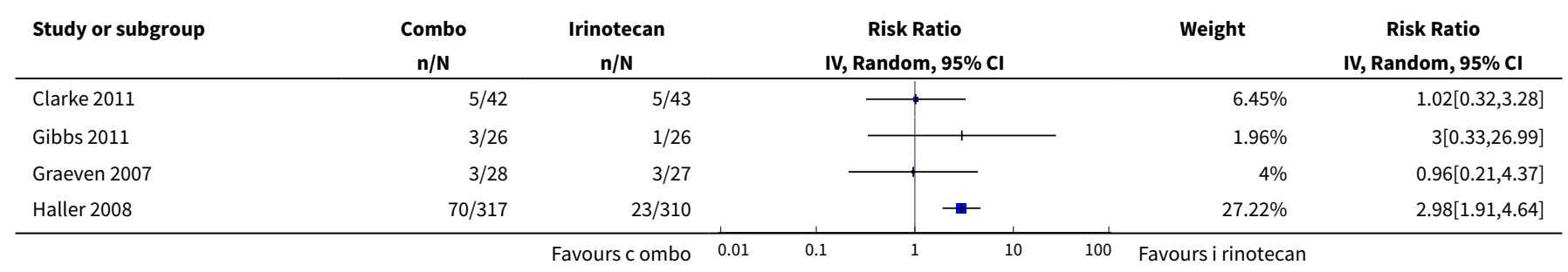




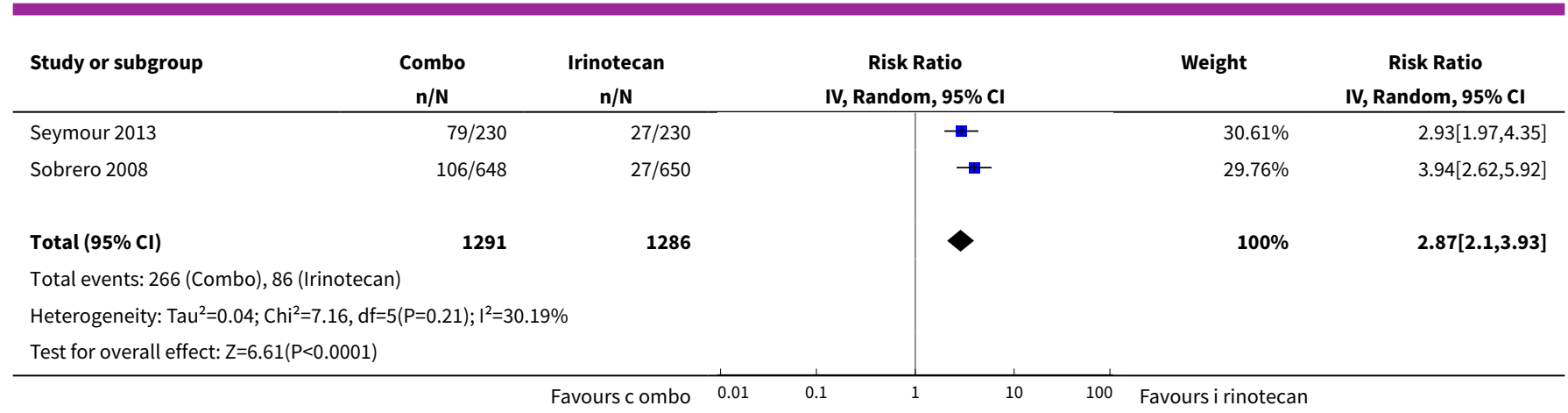

Analysis 1.8. Comparison 1 All, Outcome 8 SAE_irino combo.

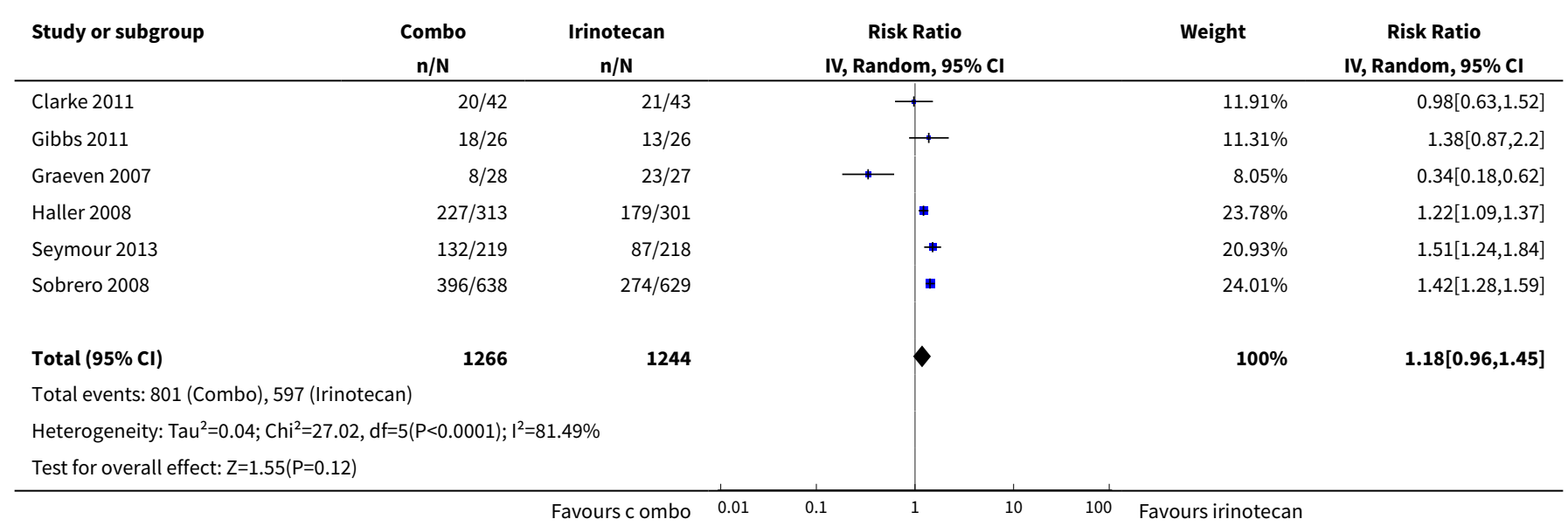

Analysis 1.9. Comparison 1 All, Outcome 9 OS_bevacizumab (beva) combo.

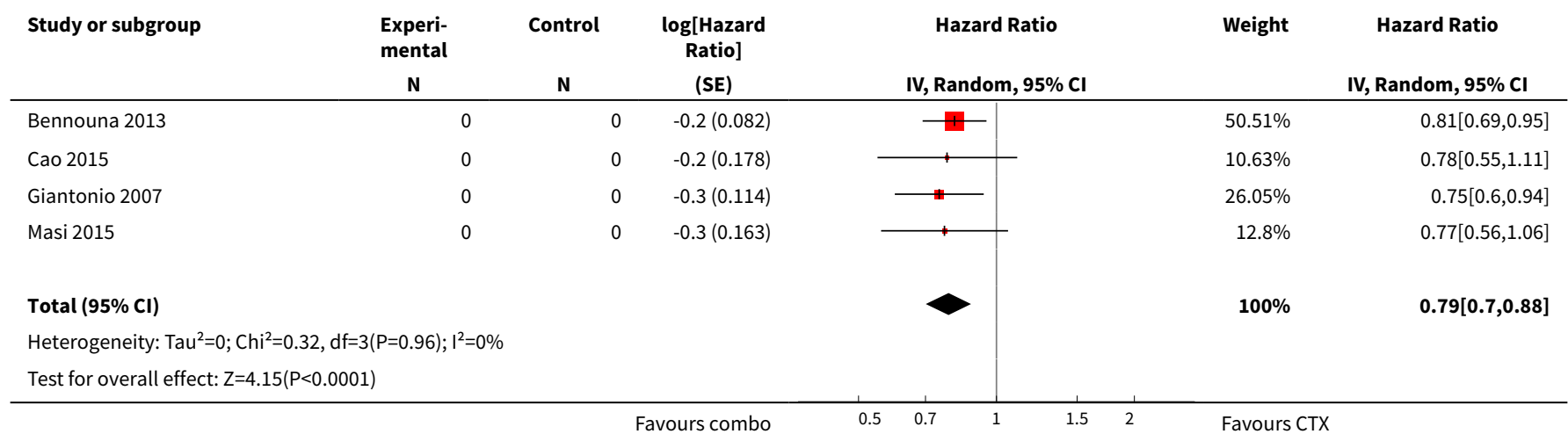


Analysis 1.10. Comparison 1 All, Outcome 10 PFS_beva combo.

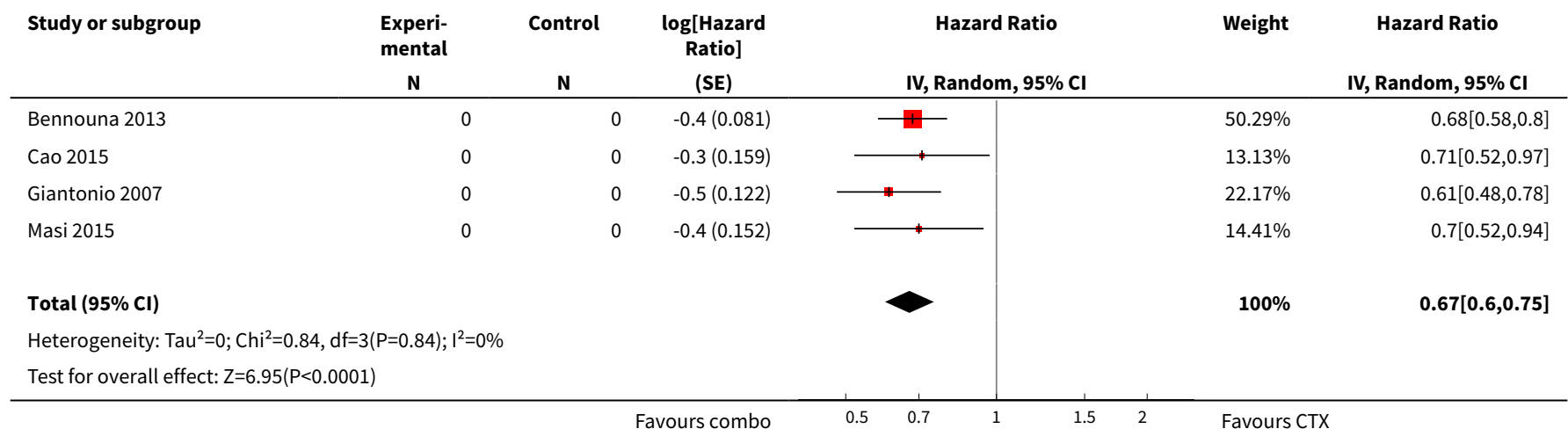

Analysis 1.11. Comparison 1 All, Outcome 11 ORR_beva combo.

\begin{tabular}{|c|c|c|c|c|c|}
\hline Study or subgroup & $\begin{array}{c}\text { Beva + CTX } \\
n / N \\
\end{array}$ & $\begin{array}{l}\text { CTX } \\
n / N\end{array}$ & $\begin{array}{c}\text { Risk Ratio } \\
\text { IV, Random, } 95 \% \mathrm{Cl}\end{array}$ & Weight & $\begin{array}{c}\text { Risk Ratio } \\
\text { IV, Random, } 95 \% \mathrm{CI}\end{array}$ \\
\hline Bennouna 2013 & $22 / 404$ & $16 / 406$ & $\rightarrow-$ & $19.31 \%$ & $1.38[0.74,2.59]$ \\
\hline Cao 2015 & $31 / 65$ & $22 / 77$ & $\rightarrow-$ & $29.3 \%$ & $1.67[1.08,2.58]$ \\
\hline Giantonio 2007 & $65 / 287$ & $25 / 291$ & $\rightarrow$ & $29.55 \%$ & $2.64[1.71,4.06]$ \\
\hline Masi 2015 & $21 / 92$ & $17 / 92$ & - & $21.85 \%$ & $1.24[0.7,2.19]$ \\
\hline \multicolumn{6}{|c|}{ Total events: 139 (Beva + CTX), 80 (СTX) } \\
\hline \multicolumn{6}{|c|}{ Heterogeneity: $\operatorname{Tau}^{2}=0.05 ; \mathrm{Chi}^{2}=5.46, \mathrm{df}=3(\mathrm{P}=0.14) ; \mathrm{I}^{2}=45.1 \%$} \\
\hline \multicolumn{6}{|c|}{ Test for overall effect: $Z=3.13(P=0)$} \\
\hline
\end{tabular}

Analysis 1.12. Comparison 1 All, Outcome 12 SAE_beva combo.

\begin{tabular}{|c|c|c|c|c|c|}
\hline Study or subgroup & $\begin{array}{c}\text { Beva + CTX } \\
n / N \\
\end{array}$ & $\begin{array}{l}\text { CTX } \\
n / N\end{array}$ & $\begin{array}{c}\text { Risk Ratio } \\
\text { IV, Random, } 95 \% \mathrm{CI}\end{array}$ & Weight & $\begin{array}{c}\text { Risk Ratio } \\
\text { IV, Random, } 95 \% \mathrm{CI}\end{array}$ \\
\hline Bennouna 2013 & $255 / 401$ & $235 / 409$ & $\mathbf{m}$ & $33.12 \%$ & $1.11[0.99,1.24]$ \\
\hline Cao 2015 & $41 / 65$ & $58 / 77$ & - & $20.94 \%$ & $0.84[0.67,1.05]$ \\
\hline Giantonio 2007 & $216 / 287$ & $174 / 285$ & $\mathbf{H}$ & $32.84 \%$ & $1.23[1.1,1.38]$ \\
\hline Masi 2015 & $40 / 92$ & $38 / 92$ & $\rightarrow$ & $13.1 \%$ & $1.05[0.75,1.47]$ \\
\hline \multicolumn{6}{|c|}{ Total events: 552 (Beva + CTX), 505 (СТX) } \\
\hline \multicolumn{6}{|c|}{ Heterogeneity: $\mathrm{Tau}^{2}=0.01 ; \mathrm{Chi}^{2}=9.27, \mathrm{df}=3(\mathrm{P}=0.03) ; \mathrm{I}^{2}=67.63 \%$} \\
\hline \multicolumn{6}{|c|}{ Test for overall effect: $\mathrm{Z}=0.95(\mathrm{P}=0.34)$} \\
\hline
\end{tabular}


Analysis 1.13. Comparison 1 All, Outcome 13 OS_FOLFIRI targeted.

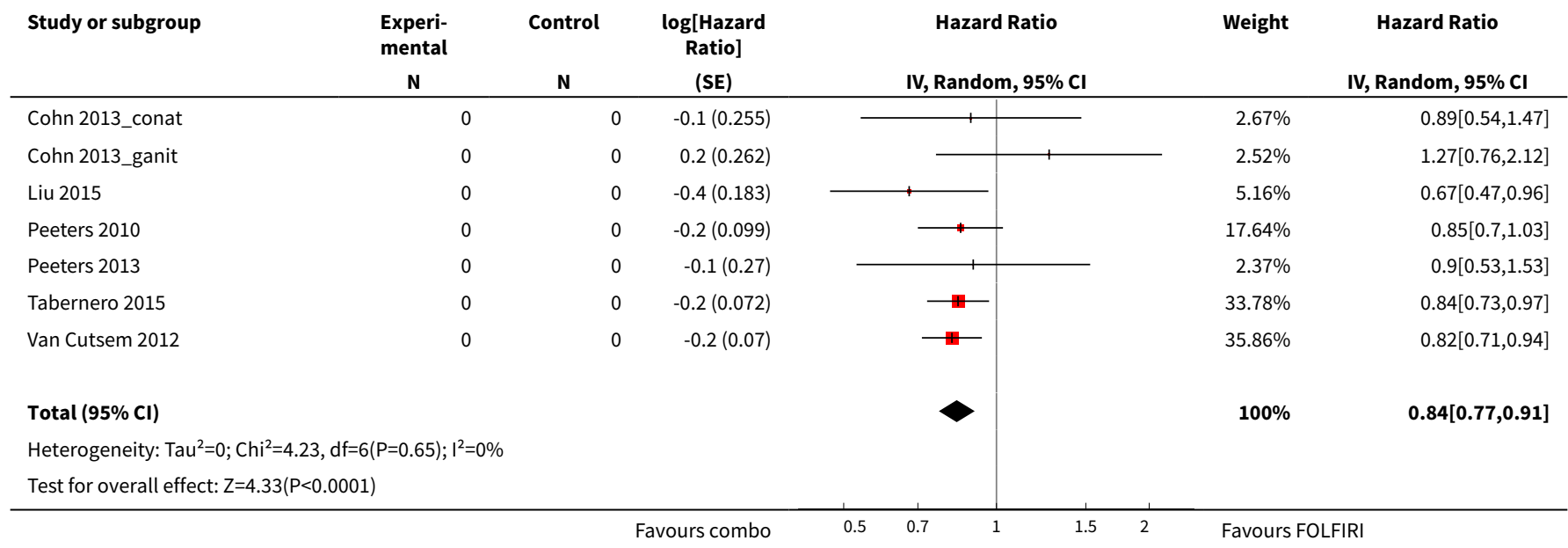

Analysis 1.14. Comparison 1 All, Outcome 14 PFS_FOLFIRI targeted.

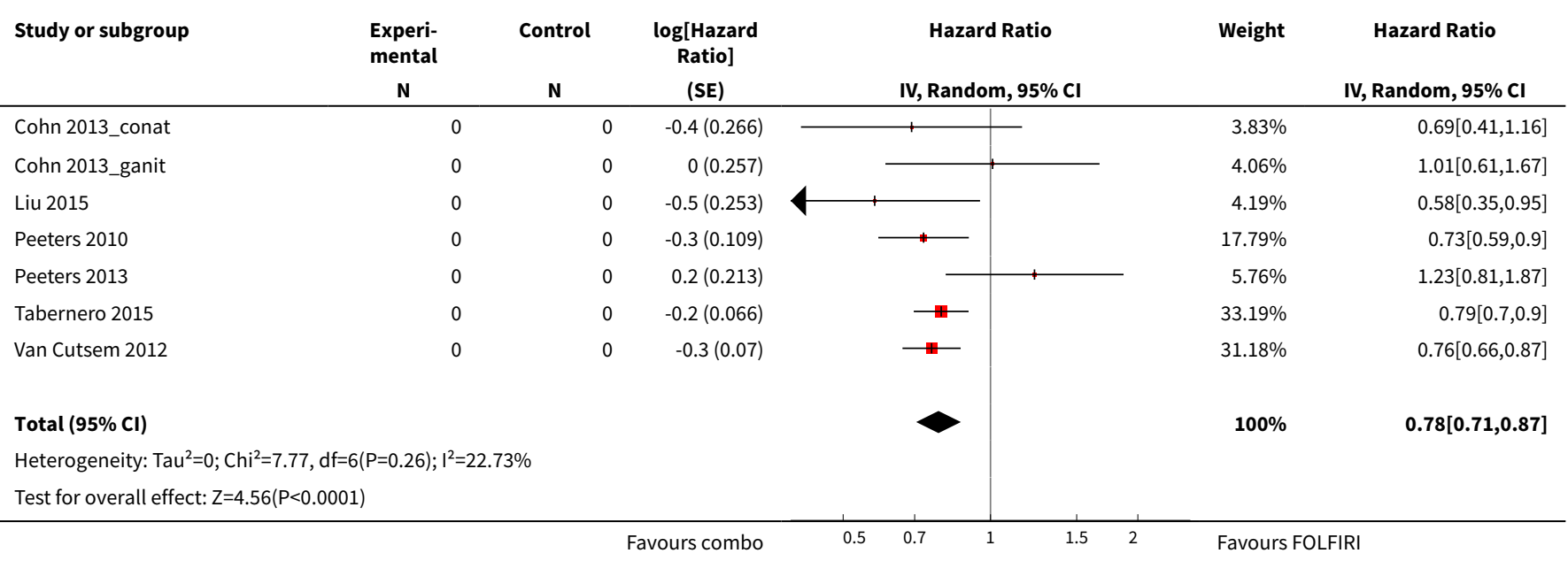

Analysis 1.15. Comparison 1 All, Outcome 15 ORR_FOLFIRI targeted.

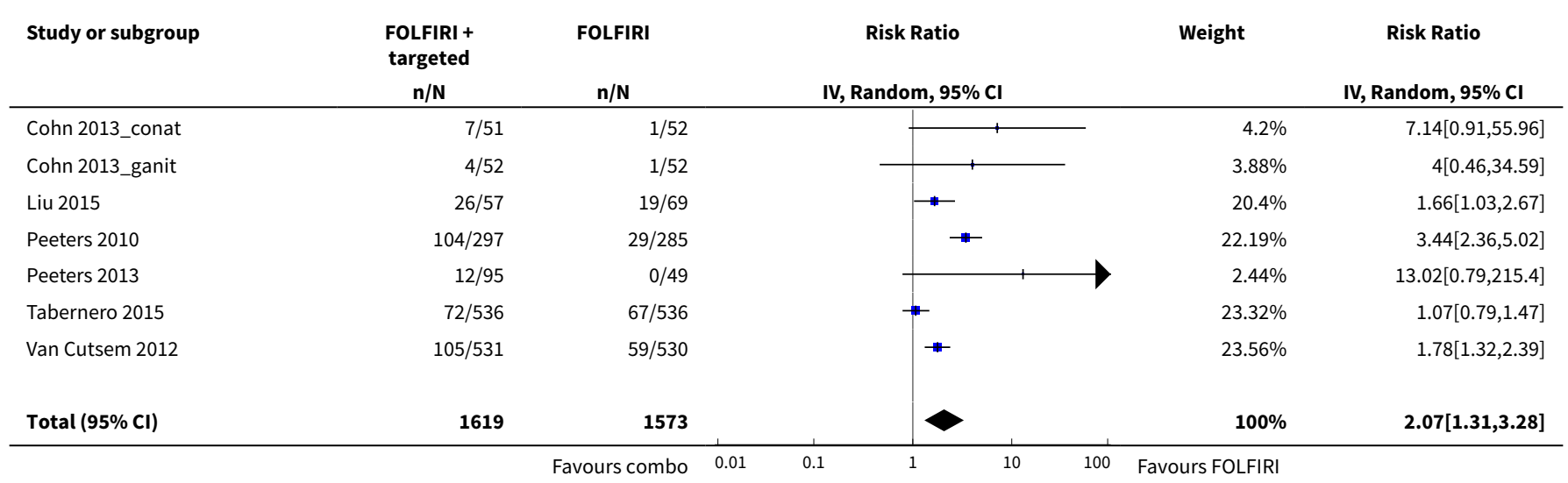




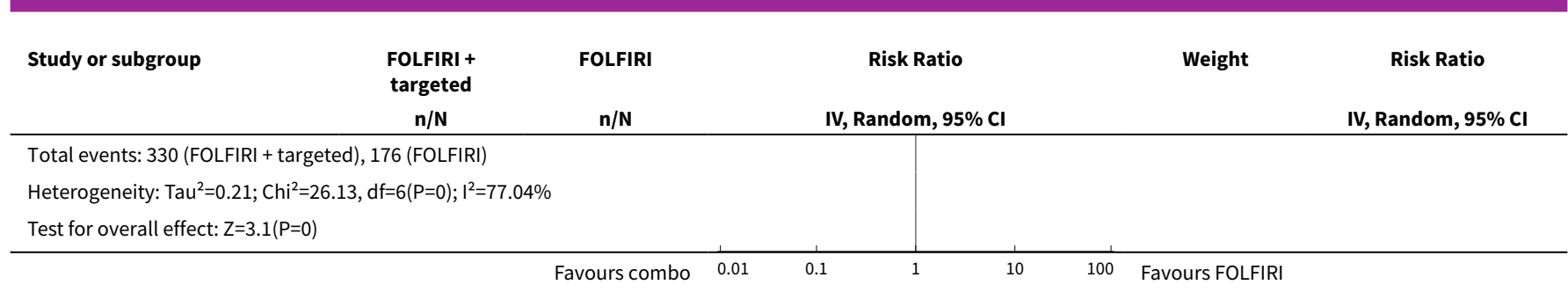

Analysis 1.16. Comparison 1 All, Outcome 16 SAE_FOLFIRI targeted.

\begin{tabular}{|c|c|c|c|c|c|}
\hline Study or subgroup & $\begin{array}{c}\text { FOLFIRI + } \\
\text { targeted } \\
\mathrm{n} / \mathrm{N} \\
\end{array}$ & $\begin{array}{c}\text { FOLFIRI } \\
\text { n/N }\end{array}$ & IV, Random, 95\% CI & Weight & $\begin{array}{c}\text { Risk Ratio } \\
\text { IV, Random, 95\% Cl }\end{array}$ \\
\hline Cohn 2013_conat & $36 / 50$ & $24 / 51$ & $\rightarrow$ & $7.32 \%$ & $1.53[1.09,2.15]$ \\
\hline Cohn 2013_ganit & $28 / 51$ & $24 / 51$ & $\rightarrow$ & $6.05 \%$ & $1.17[0.8,1.71]$ \\
\hline Liu 2015 & $53 / 57$ & $40 / 69$ & + & $13.37 \%$ & $1.6[1.3,1.99]$ \\
\hline Peeters 2010 & $219 / 302$ & $152 / 294$ & * & $20.23 \%$ & $1.4[1.23,1.6]$ \\
\hline Tabernero 2015 & $189 / 529$ & $164 / 528$ & + & $16.58 \%$ & $1.15[0.97,1.36]$ \\
\hline Van Cutsem 2012 & $510 / 611$ & $378 / 605$ & - & $25.82 \%$ & $1.34[1.24,1.43]$ \\
\hline Total $(95 \% \mathrm{Cl})$ & 1694 & 1647 & $\checkmark$ & $100 \%$ & $1.3[1.17,1.45]$ \\
\hline \multicolumn{6}{|c|}{ Total events: 1093 (FOLFIRI + targeted), 814 (FOLFIRI) } \\
\hline \multicolumn{6}{|c|}{ Heterogeneity: $\operatorname{Tau}^{2}=0.01 ; \mathrm{Chi}^{2}=14.17, \mathrm{df}=6(\mathrm{P}=0.03) ; \mathrm{I}^{2}=57.66 \%$} \\
\hline
\end{tabular}

Analysis 1.17. Comparison 1 All, Outcome 17 OS_FOLFOX targeted.

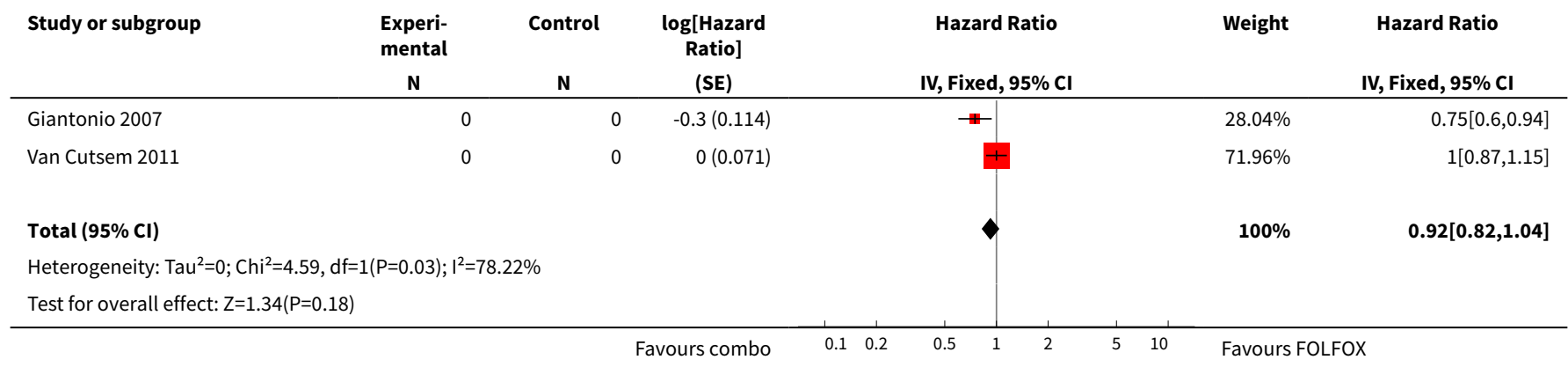

Analysis 1.18. Comparison 1 All, Outcome 18 PFS_FOLFOX targeted.

\begin{tabular}{|c|c|c|c|c|c|c|c|}
\hline \multirow[t]{2}{*}{ Study or subgroup } & \multirow{2}{*}{$\begin{array}{c}\text { Experi- } \\
\text { mental } \\
\mathbf{N}\end{array}$} & \multirow{2}{*}{$\begin{array}{l}\text { Control } \\
\text { N }\end{array}$} & \multirow{2}{*}{$\begin{array}{l}\log [\text { Hazard } \\
\text { Ratio] } \\
\text { (SE) }\end{array}$} & \multicolumn{2}{|c|}{ Hazard Ratio } & \multirow[t]{2}{*}{ Weight } & \multirow{2}{*}{$\begin{array}{c}\text { Hazard Ratio } \\
\text { IV, Fixed, } 95 \% \mathrm{CI}\end{array}$} \\
\hline & & & & IV, Fi & $\mathrm{Cl}$ & & \\
\hline Giantonio 2007 & 0 & 0 & $-0.5(0.122)$ & $\square$ & & $29.81 \%$ & $0.61[0.48,0.78]$ \\
\hline Van Cutsem 2011 & 0 & 0 & $-0.2(0.08)$ & & & $70.19 \%$ & $0.83[0.71,0.97]$ \\
\hline
\end{tabular}




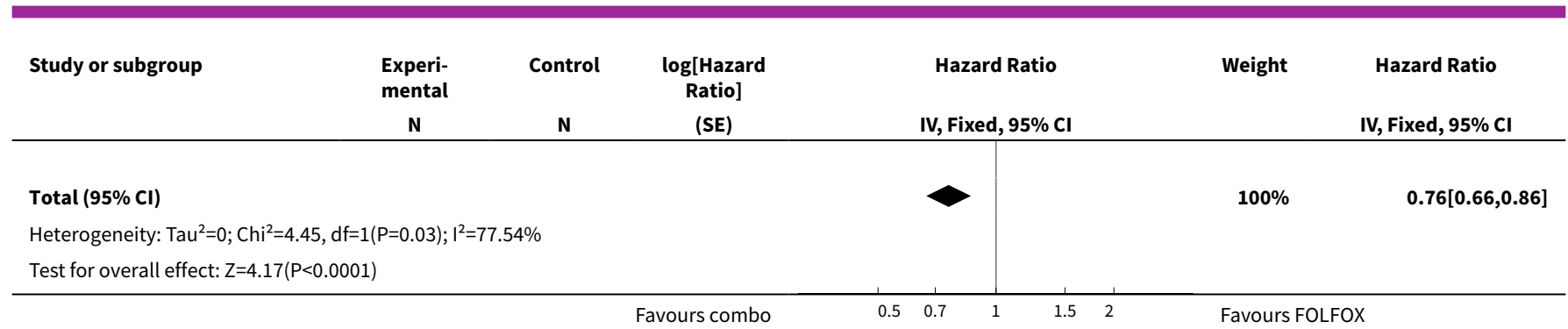

Analysis 1.19. Comparison 1 All, Outcome 19 ORR_FOLFOX targeted.

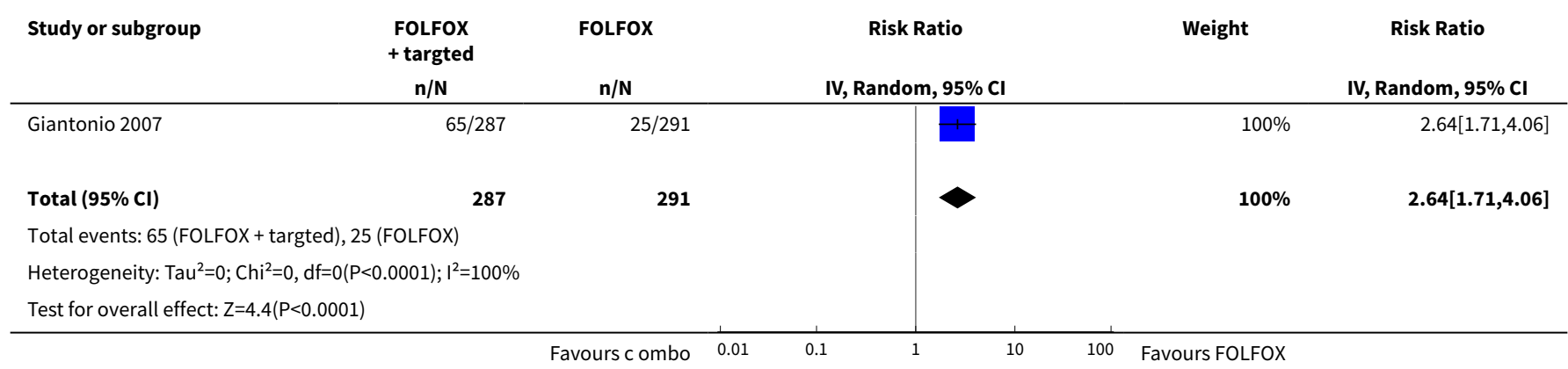

Analysis 1.20. Comparison 1 All, Outcome 20 SAE_FOLFOX targeted.

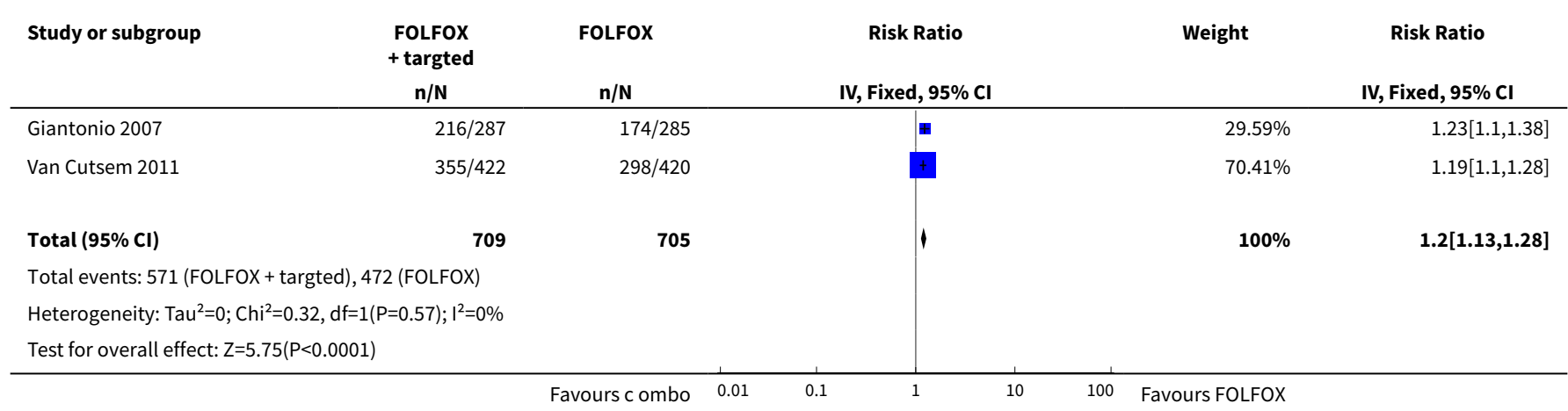

Analysis 1.21. Comparison 1 All, Outcome 21 OS_irino fraction.

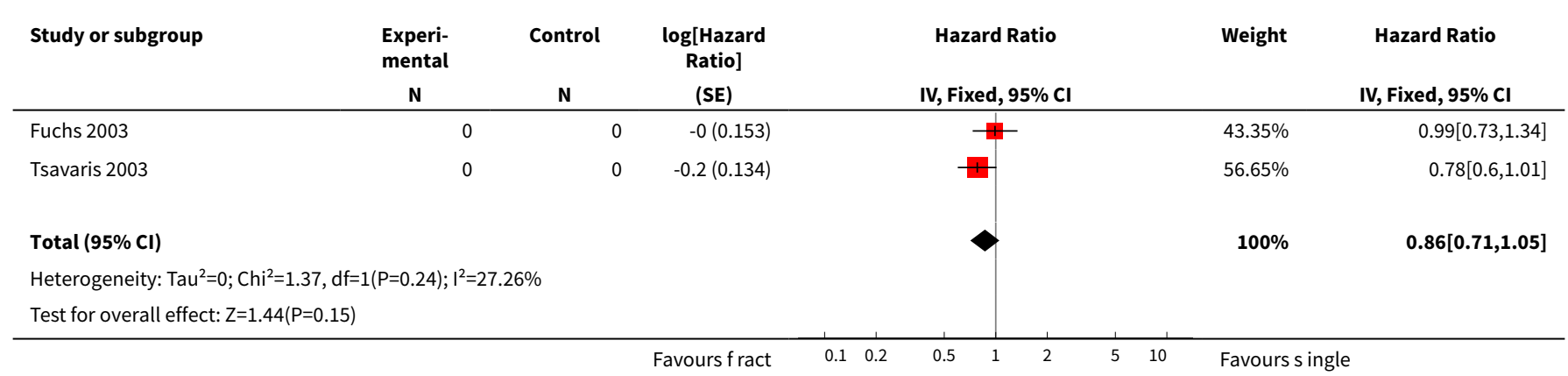


Analysis 1.22. Comparison 1 All, Outcome 22 PFS_irino fraction.

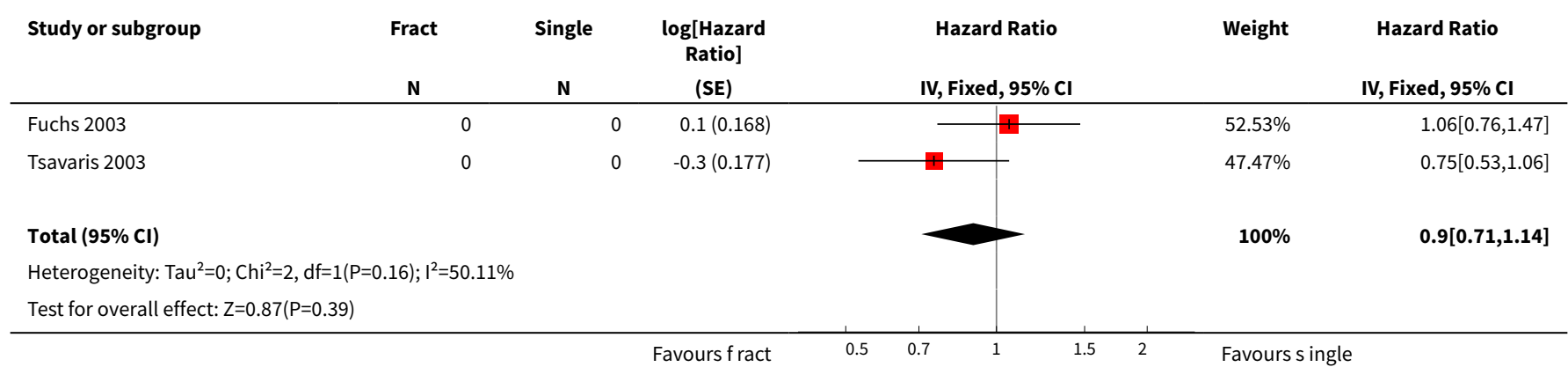

Analysis 1.23. Comparison 1 All, Outcome 23 ORR_irino fraction.

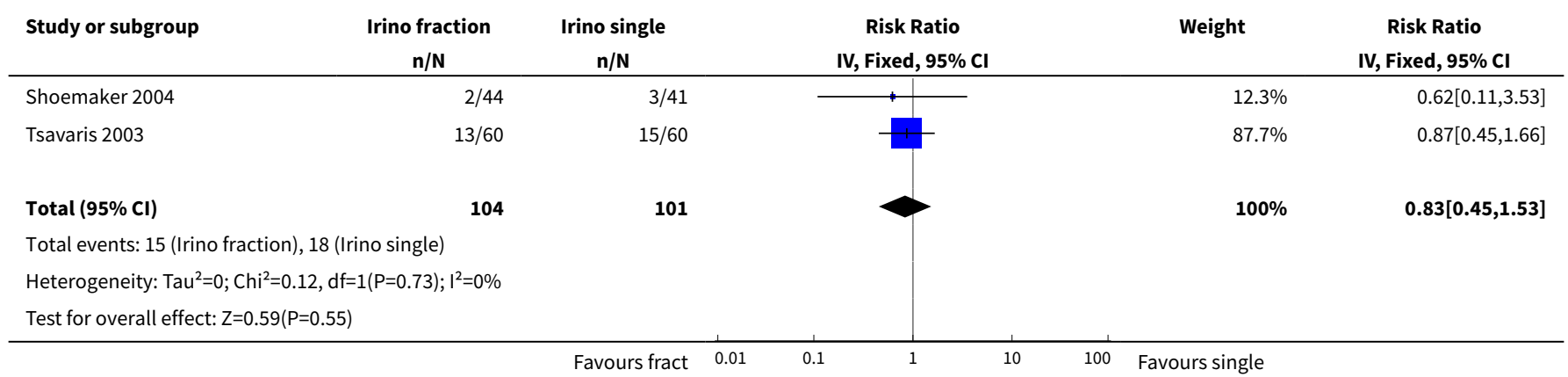

Analysis 1.24. Comparison 1 All, Outcome 24 SAE_irino fraction.

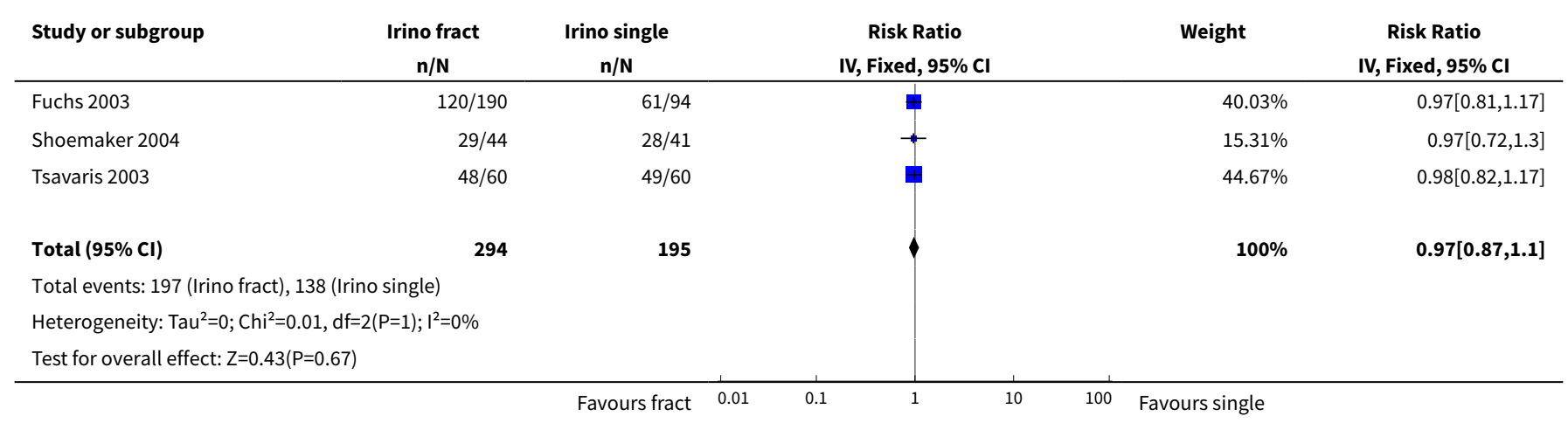


Analysis 1.25. Comparison 1 All, Outcome 25 OS_FOLFIRI + beva vs other targeted.

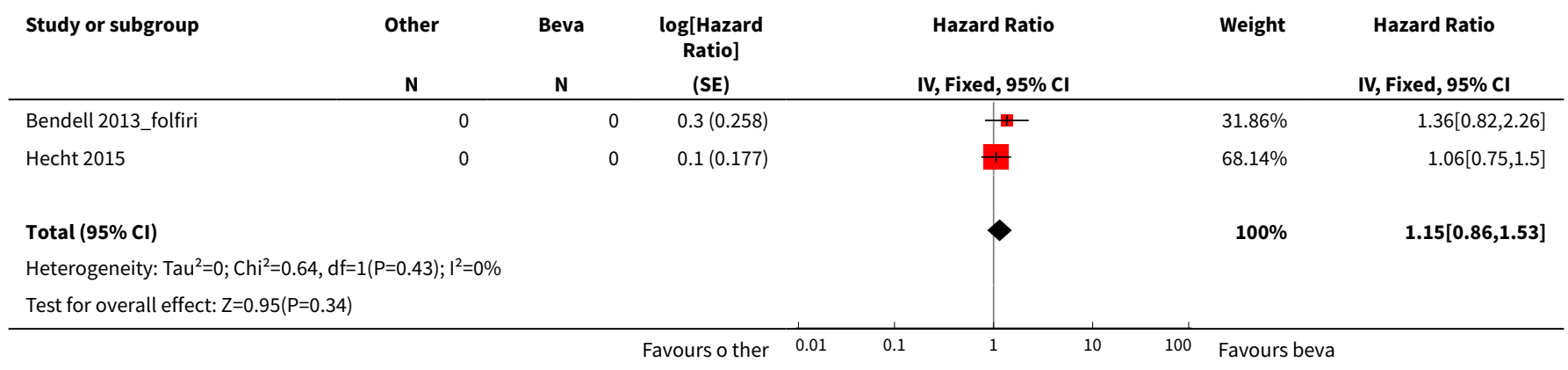

Analysis 1.26. Comparison 1 All, Outcome 26 PFS_FOLFIRI + beva vs other targeted.

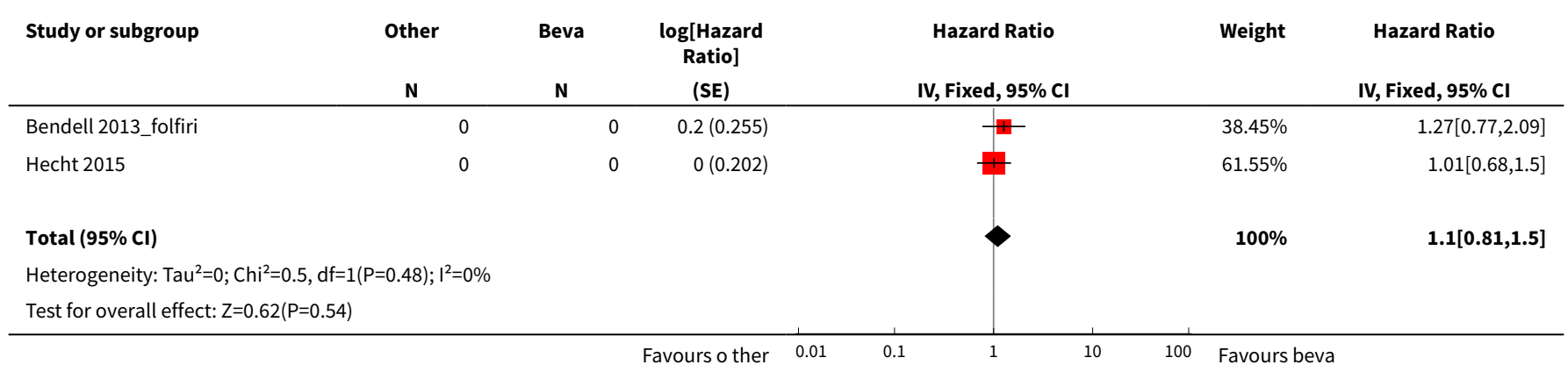

Analysis 1.27. Comparison 1 All, Outcome 27 ORR_FOLFIRI + beva vs other targeted.

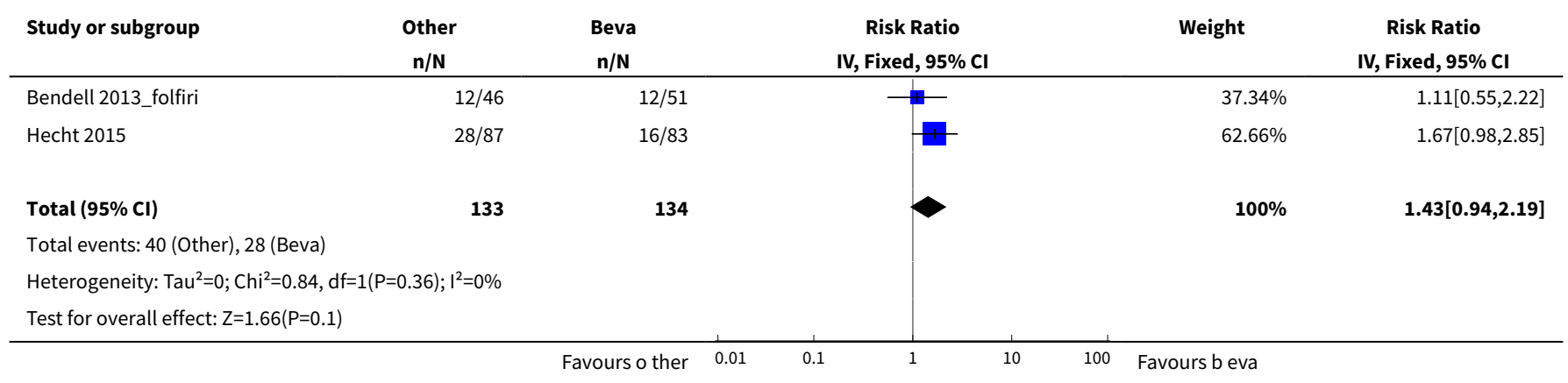

Analysis 1.28. Comparison 1 All, Outcome 28 SAE_FOLFIRI + beva vs other targeted.

\begin{tabular}{|c|c|c|c|c|c|}
\hline Study or subgroup & $\begin{array}{c}\text { Other } \\
\mathrm{n} / \mathrm{N}\end{array}$ & $\begin{array}{l}\text { Beva } \\
n / N\end{array}$ & $\begin{array}{c}\text { Risk Ratio } \\
\text { IV, Fixed, 95\% CI }\end{array}$ & Weight & $\begin{array}{c}\text { Risk Ratio } \\
\text { IV, Fixed, 95\% CI }\end{array}$ \\
\hline Bendell 2013_folfiri & $17 / 46$ & $9 / 51$ & $\longrightarrow$ & $21.47 \%$ & $2.09[1.04,4.23]$ \\
\hline Total $(95 \% \mathrm{CI})$ & 137 & 142 & & $100 \%$ & $1.53[1.1,2.11]$ \\
\hline
\end{tabular}




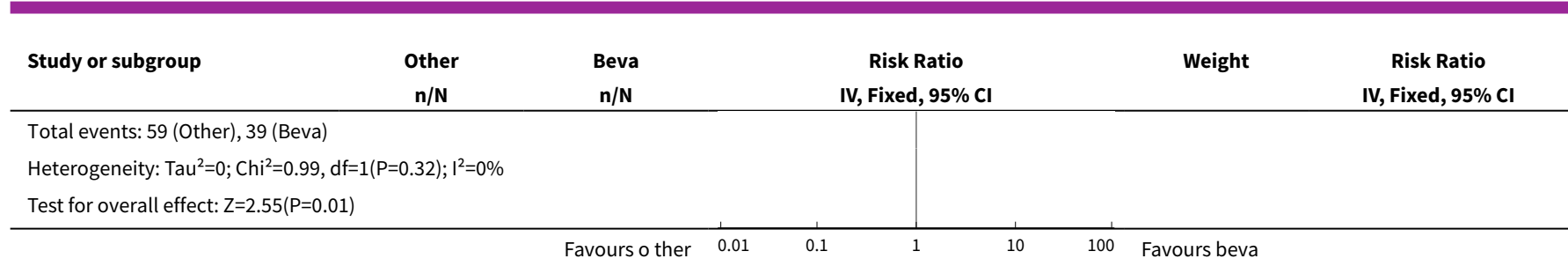

Analysis 1.29. Comparison 1 All, Outcome 29 OS_FOLFOX + beva vs other targeted.

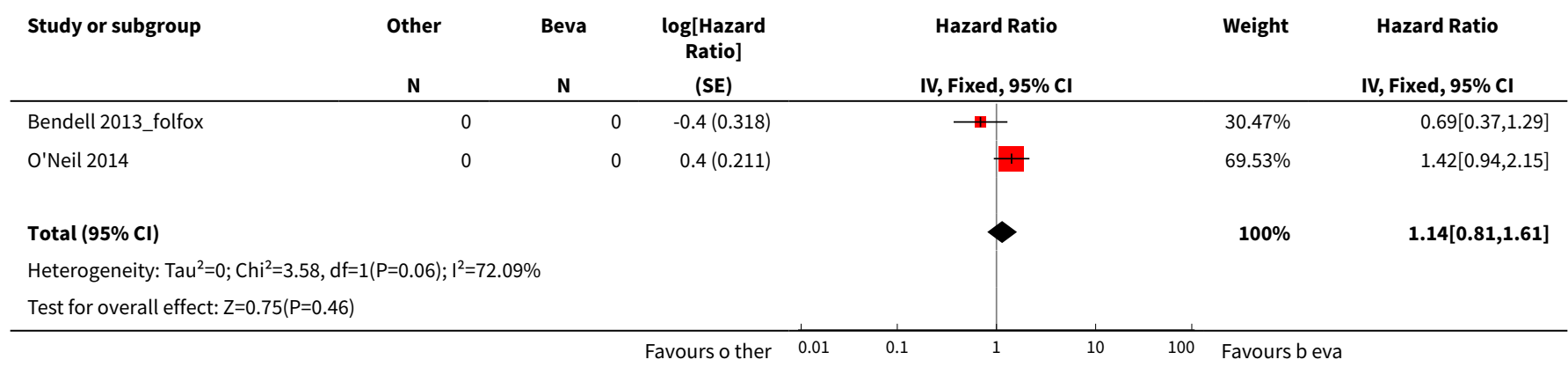

Analysis 1.30. Comparison 1 All, Outcome 30 PFS_FOLFOX + beva vs other targeted.

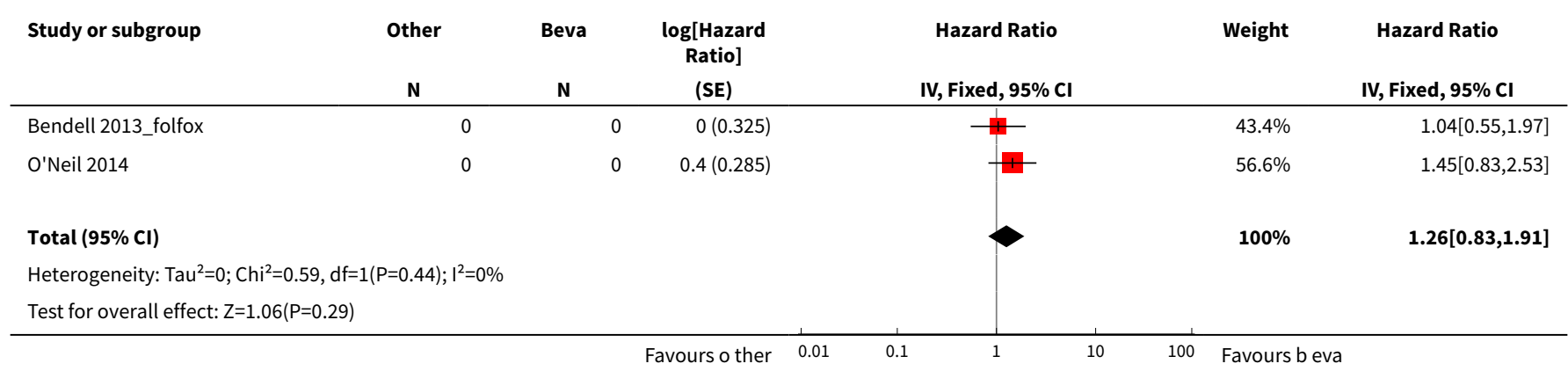

Analysis 1.31. Comparison 1 All, Outcome 31 ORR_FOLFOX + beva vs other targeted.

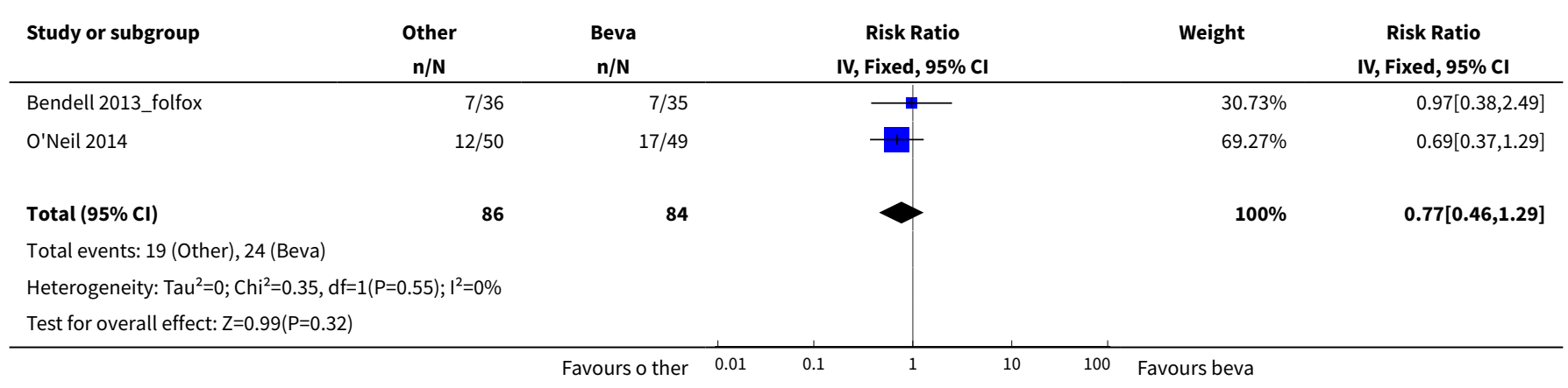


Analysis 1.32. Comparison 1 All, Outcome 32 SAE_FOLFOX + beva vs other targeted.

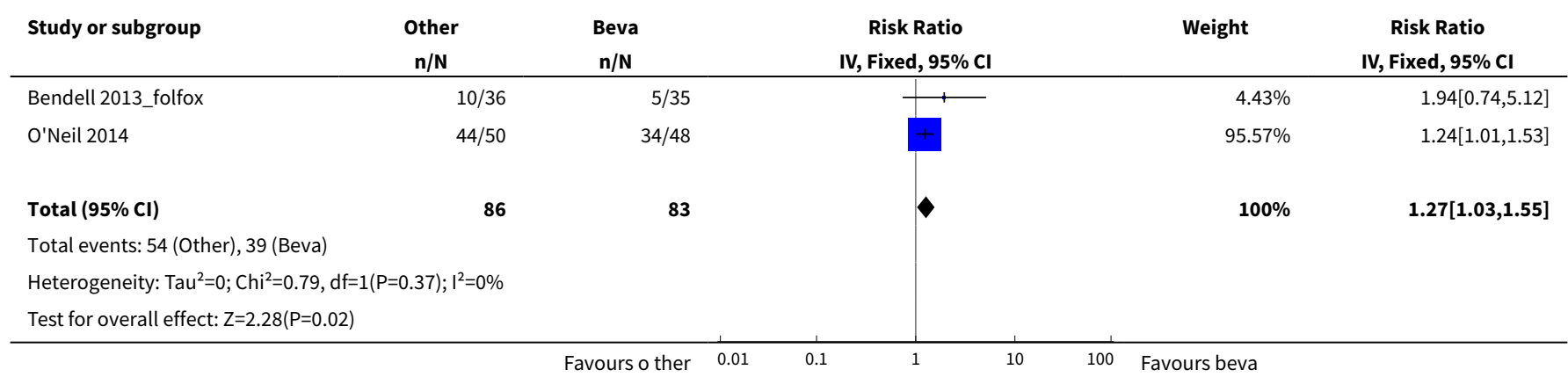

\section{ADDITIONAL TABLES}

Table 1. List of abbreviations

\begin{tabular}{|c|c|}
\hline Acronym & Full name \\
\hline $5 F U$ & 5-fluorouracil \\
\hline Ang1 & Angiopoietin-1 \\
\hline Ang2 & Angiopoietin-2 \\
\hline CRC & Colorectal cancer \\
\hline CTX & Chemotherapy \\
\hline DR5 & Death receptor 5 \\
\hline EGFR & Epithelial growth factor receptor \\
\hline FOLFIRI & Fluorouracil + irinotecan + leucovorin \\
\hline FOLFOX & Fluorouracil + oxaliplatin + leucovorin \\
\hline $\mathrm{HR}$ & Hazard ratio \\
\hline IGF1R & Insulin-like growth factor 1 receptor \\
\hline IRIS & S-1 + irinotecan \\
\hline i.v. & Intravenous \\
\hline KRAS & Name of a gene whose product acts downstream of EGFR \\
\hline ORR & Overall response rate \\
\hline OS & Overall survival \\
\hline PDGFR & Platelet derived growth factor receptor \\
\hline PFS & Progression-free survival \\
\hline
\end{tabular}


Table 1. List of abbreviations (Continued)

\begin{tabular}{ll} 
QoL & Quality of life \\
\hline RCT & Randomized controlled trial \\
\hline RR & Risk ratio \\
\hline SAE & Severe adverse event \\
\hline VEGF & Vascular endothelium growth factor \\
\hline VEGFR & VEGF receptor \\
\hline XELOX & Capecitabine + oxaliplatin \\
\hline
\end{tabular}

Table 2. Main features of anticancer agents

\begin{tabular}{|c|c|c|c|}
\hline $\begin{array}{l}\text { Name (abbrevia- } \\
\text { tion) }\end{array}$ & Class & Mechanism of action & $\begin{array}{l}\text { Route of adminis- } \\
\text { tration }\end{array}$ \\
\hline 5-fluorouracil (5FU) & $\begin{array}{l}\text { Chemotherapy } \\
\text { agent }\end{array}$ & $\begin{array}{l}\text { Antimetabolite (pyrimidine analogue) inhibiting RNA synthesis } \\
\text { and the enzyme thymidylate synthase (which converts dUMP to } \\
\text { dTMP which in turn is needed for the synthesis of DNA) }\end{array}$ & Intravenous \\
\hline Oxaliplatin & $\begin{array}{l}\text { Chemotherapy } \\
\text { agent }\end{array}$ & $\begin{array}{l}\text { Alkylating agent binding covalently to DNA, which in turn in- } \\
\text { hibits DNA replication or causes DNA breaks }\end{array}$ & Intravenous \\
\hline Irinotecan & $\begin{array}{l}\text { Chemotherapy } \\
\text { agent }\end{array}$ & $\begin{array}{l}\text { Inhibits the enzyme topoisomerase-I, which is involved in DNA } \\
\text { replication or transcription }\end{array}$ & Intravenous \\
\hline Mitomycin-C & $\begin{array}{l}\text { Chemotherapy } \\
\text { agent }\end{array}$ & $\begin{array}{l}\text { Alkylating agent binding covalently to DNA, which in turn in- } \\
\text { hibits DNA replication or causes DNA breaks }\end{array}$ & Intravenous \\
\hline Raltitrexed & $\begin{array}{l}\text { Chemotherapy } \\
\text { agent }\end{array}$ & $\begin{array}{l}\text { Antimetabolite that inhibits the enzyme thymidylate synthase } \\
\text { (which converts dUMP to dTMP which in turn is needed for the } \\
\text { synthesis of DNA) }\end{array}$ & Intravenous \\
\hline Capecitabine & $\begin{array}{l}\text { Chemotherapy } \\
\text { agent }\end{array}$ & $\begin{array}{l}\text { It is a prodrug of 5FU: one within the cells, it is transformed into } \\
\text { the active drug }\end{array}$ & Oral \\
\hline S-1 & $\begin{array}{l}\text { Chemotherapy } \\
\text { agent }\end{array}$ & $\begin{array}{l}\text { Antimetabolite (pyrimidine analogue) inhibiting RNA synthesis } \\
\text { and the enzyme thymidylate synthase (which converts dUMP to } \\
\text { dTMP which in turn is needed for the synthesis of DNA) }\end{array}$ & Oral \\
\hline Bevacizumab & Targeted drug & $\begin{array}{l}\text { Monoclonal antibody blocking VEGF (a ligand of VEGFR, a re- } \\
\text { ceptor involved in angiogenesis) }\end{array}$ & Intravenous \\
\hline Cetuximab & Targeted drug & $\begin{array}{l}\text { Monoclonal antibody blocking EGFR (a receptor involved in cell } \\
\text { proliferation); best works against KRAS wild-type tumours }\end{array}$ & Intravenous \\
\hline Panituzumab & Targeted drug & $\begin{array}{l}\text { Monoclonal antibody blocking EGFR (a receptor involved in cell } \\
\text { proliferation); best works against KRAS wild-type tumours }\end{array}$ & Intravenous \\
\hline Conatumumab & Targeted drug & $\begin{array}{l}\text { Monoclonal antibody activating DR5 (a receptor involved in cell } \\
\text { apoptosis) }\end{array}$ & Intravenous \\
\hline
\end{tabular}


Table 2. Main features of anticancer agents (Continued)

\begin{tabular}{lllll} 
Ganitumab & Targeted drug & $\begin{array}{l}\text { Monoclonal antibody blocking IGF1R (a receptor involved in cell } \\
\text { proliferation) }\end{array}$ & Intravenous \\
\hline Ramucirumab & Targeted drug & $\begin{array}{l}\text { Monoclonal antibody blocking VEGFR (a receptor involved in } \\
\text { angiogenesis) }\end{array}$ & Intravenous \\
\hline Abituzumab & Targeted drug & $\begin{array}{l}\text { Monoclonal antibody blocking integrin-alphaV (a molecule in- } \\
\text { volved in cell adhesion) }\end{array}$ & Intravenous \\
\hline Trebananib & Targeted drug & $\begin{array}{l}\text { Recombinant protein blocking Ang1 and Ang2 (ligands of Tie2, } \\
\text { a receptor involved in angiogenesis) }\end{array}$ & Intravenous \\
\hline Aflibercept & Targeted drug & $\begin{array}{l}\text { Recombinant protein blocking VEGF (a ligand of VEGFR, a re- } \\
\text { ceptor involved in angiogenesis) }\end{array}$ & Intravenous \\
\hline Vatalanib & Targeted drug & $\begin{array}{l}\text { Small molecule inhibitor of multiple tyrosine kinases such as } \\
\text { VEGFR (a receptor involved in angiogenesis) and PDGFR (a re- } \\
\text { ceptor involved in cell proliferation) }\end{array}$ & Oral \\
\hline Gefitinib & Targeted drug & $\begin{array}{l}\text { Small molecule inhibitor of tyrosine kinase EGFR (a receptor } \\
\text { involved in cell proliferation); best works against EGFR mutat- } \\
\text { ed/KRAS wild-type tumours }\end{array}$ & Oral
\end{tabular}

Ang1: angiopoietin-1, Ang2: angiopoietin-2; DR5: death receptor 5; dTMP: deoxythymidine monophosphate; dUMP: deoxyuridine monophosphate; IGF1R: insulin-like growth factor 1 receptor; PDGFR: platelet-derived growth factor receptor; RNA: ribonucleic acid; VEGF: vascular endothelial growth factor; VEGFR: VEGF receptor.

Table 3. Summary of studies' results

\begin{tabular}{|c|c|c|c|c|c|}
\hline Study & Comparison & $\begin{array}{l}\text { OS (HR, 95\% } \\
\mathrm{Cl})\end{array}$ & $\begin{array}{l}\text { PFS (HR, 95\% } \\
\mathrm{Cl})\end{array}$ & $\begin{array}{l}\text { ORR (RR, 95\% } \\
\mathrm{Cl})\end{array}$ & $\begin{array}{l}\text { SAE (RR, 95\% } \\
\text { CI) }\end{array}$ \\
\hline $\begin{array}{l}\text { Bendell } \\
\text { 2013_folfiri }\end{array}$ & $\begin{array}{l}\text { Axitinib + FOLFIRI vs bevacizumab + } \\
\text { FOLFIRI }\end{array}$ & $\begin{array}{l}1.36(0.82 \text { to } \\
2.26)\end{array}$ & $\begin{array}{l}1.27(0.77 \text { to } \\
2.09)\end{array}$ & $\begin{array}{l}1.11(0.55 \text { to } \\
2.22)\end{array}$ & $\begin{array}{l}2.09(1.04 \text { to } \\
4.23)\end{array}$ \\
\hline $\begin{array}{l}\text { Bendell } \\
\text { 2013_folfox }\end{array}$ & $\begin{array}{l}\text { Axitinib + FOLFOX vs bevacizumab + } \\
\text { FOLFOX }\end{array}$ & $\begin{array}{l}0.69(0.37 \text { to } \\
1.29)\end{array}$ & $\begin{array}{l}1.04(0.55 \text { to } \\
1.97)\end{array}$ & $\begin{array}{l}0.97(0.38 \text { to } \\
2.49)\end{array}$ & $\begin{array}{l}1.94(0.74 \text { to } \\
5.12)\end{array}$ \\
\hline $\begin{array}{l}\text { Bennouna } \\
2013\end{array}$ & $\begin{array}{l}\text { Bevacizumab + chemotherapy vs } \\
\text { chemotherapy }\end{array}$ & $\begin{array}{l}0.81(0.69 \text { to } \\
0.95)\end{array}$ & $\begin{array}{l}0.68(0.58 \text { to } \\
0.80)\end{array}$ & $\begin{array}{l}1.38(0.74 \text { to } \\
2.59)\end{array}$ & $\begin{array}{l}1.11(0.99 \text { to } \\
1.24)\end{array}$ \\
\hline Cao 2015 & Bevacizumab + FOLFIRI vs FOLFIRI & $\begin{array}{l}0.78 \text { (0.55 to } \\
1.11)\end{array}$ & $\begin{array}{l}0.71(0.52 \text { to } \\
0.97)\end{array}$ & $\begin{array}{l}1.67 \text { (1.08 to } \\
2.58)\end{array}$ & $\begin{array}{l}0.84 \text { (0.67 to } \\
1.05)\end{array}$ \\
\hline Clarke 2011 & FOLFIRI vs irinotecan & $\begin{array}{l}0.72 \text { ( } 0.46 \text { to } \\
1.13)\end{array}$ & $\begin{array}{l}0.81 \text { ( } 0.52 \text { to } \\
1.26)\end{array}$ & $\begin{array}{l}1.02 \text { ( } 0.32 \text { to } \\
3.28)\end{array}$ & $\begin{array}{l}0.98 \text { ( } 0.63 \text { to } \\
1.52)\end{array}$ \\
\hline $\begin{array}{l}\text { Cohn } \\
\text { 2013_conat }\end{array}$ & Conatumumab + FOLFIRI vs FOLFIRI & $\begin{array}{l}0.89 \text { (0.54 to } \\
1.47)\end{array}$ & $\begin{array}{l}0.69 \text { ( } 0.41 \text { to } \\
1.16)\end{array}$ & $\begin{array}{l}7.14 \text { (0.91 to } \\
55.96)\end{array}$ & $\begin{array}{l}1.53 \text { (1.09 to } \\
2.15)\end{array}$ \\
\hline $\begin{array}{l}\text { Cohn } \\
\text { 2013_ganit }\end{array}$ & Ganitumab + FOLFIRI vs FOLFIRI & $\begin{array}{l}1.27 \text { ( } 0.76 \text { to } \\
2.12)\end{array}$ & $\begin{array}{l}1.01 \text { ( } 0.61 \text { to } \\
1.67)\end{array}$ & $\begin{array}{l}4.00(0.46 \text { to } \\
34.59)\end{array}$ & $\begin{array}{l}1.17 \text { ( } 0.80 \text { to } \\
1.71 \text { ) }\end{array}$ \\
\hline $\begin{array}{l}\text { Cunningham } \\
1998\end{array}$ & Irinotecan vs best supportive care & $\begin{array}{l}0.58(0.43 \text { to } \\
0.80)\end{array}$ & Not available & Not available & $\begin{array}{l}1.19(1.01 \text { to } \\
1.40)\end{array}$ \\
\hline
\end{tabular}


Table 3. Summary of studies' results (Continued)

\begin{tabular}{|c|c|c|c|c|c|}
\hline Élez 2015 & $\begin{array}{l}\text { Abituzumab + cetuximab + irinotecan } \\
\text { vs cetuximab + irinotecan }\end{array}$ & $\begin{array}{l}0.83(0.54 \text { to } \\
1.28)\end{array}$ & $\begin{array}{l}1.13(0.78 \text { to } \\
1.64)\end{array}$ & $\begin{array}{l}1.04(0.61 \text { to } \\
1.78)\end{array}$ & $\begin{array}{l}0.91(0.60 \text { to } \\
1.38)\end{array}$ \\
\hline Fuchs 2003 & $\begin{array}{l}\text { Irinotecan schedule } 1 \text { vs irinotecan } \\
\text { schedule } 2\end{array}$ & $\begin{array}{l}0.99(0.73 \text { to } \\
1.34)\end{array}$ & $\begin{array}{l}1.06(0.76 \text { to } \\
1.47)\end{array}$ & Not available & $\begin{array}{l}0.97(0.81 \text { to } \\
1.17)\end{array}$ \\
\hline $\begin{array}{l}\text { Giantonio } \\
2007\end{array}$ & Bevacizumab + FOLFOX vs FOLFOX & $\begin{array}{l}0.75 \text { ( } 0.60 \text { to } \\
0.94)\end{array}$ & $\begin{array}{l}0.61(0.48 \text { to } \\
0.78)\end{array}$ & $\begin{array}{l}2.64(1.71 \text { to } \\
4.06)\end{array}$ & $\begin{array}{l}1.23(1.10 \text { to } \\
1.38)\end{array}$ \\
\hline Gibbs 2011 & Hyaluronan + irinotecan vs irinotecan & $\begin{array}{l}0.93(0.49 \text { to } \\
1.76)\end{array}$ & $\begin{array}{l}0.56(0.33 \text { to } \\
0.95)\end{array}$ & $\begin{array}{l}3.00(0.33 \text { to } \\
26.99)\end{array}$ & $\begin{array}{l}1.38(0.87 \text { to } \\
2.20)\end{array}$ \\
\hline Graeven 2007 & FOLFIRI vs irinotecan & $\begin{array}{l}1.31(0.68 \text { to } \\
2.52)\end{array}$ & $\begin{array}{l}0.87(0.48 \text { to } \\
1.58)\end{array}$ & $\begin{array}{l}0.96(0.21 \text { to } \\
4.37)\end{array}$ & $\begin{array}{l}0.34(0.18 \text { to } \\
0.62)\end{array}$ \\
\hline Haller 2008 & Oxaliplatin + irinotecan vs irinotecan & $\begin{array}{l}0.78(0.67 \text { to } \\
0.90)\end{array}$ & $\begin{array}{l}0.60(0.55 \text { to } \\
0.66)\end{array}$ & $\begin{array}{l}2.98(1.91 \text { to } \\
4.64)\end{array}$ & $\begin{array}{l}1.22(1.09 \text { to } \\
1.37)\end{array}$ \\
\hline Hecht 2015 & $\begin{array}{l}\text { Panitumumab + FOLFIRI vs beva- } \\
\text { cizumab + FOLFIRI }\end{array}$ & $\begin{array}{l}1.06(0.75 \text { to } \\
1.50)\end{array}$ & $\begin{array}{l}1.01(0.68 \text { to } \\
1.50)\end{array}$ & $\begin{array}{l}1.67(0.98 \text { to } \\
2.85)\end{array}$ & $\begin{array}{l}1.40(0.97 \text { to } \\
2.02)\end{array}$ \\
\hline Iwamoto 2015 & $\begin{array}{l}\text { Bevacizumab schedule } 1+\text { FOLFIRI vs } \\
\text { bevacizumab schedule } 2+\text { FOLFIRI }\end{array}$ & $\begin{array}{l}1.08(0.75 \text { to } \\
1.56)\end{array}$ & $\begin{array}{l}0.95(0.75 \text { to } \\
1.20)\end{array}$ & $\begin{array}{l}1.04(0.58 \text { to } \\
1.86)\end{array}$ & $\begin{array}{l}1.07(0.92 \text { to } \\
1.26)\end{array}$ \\
\hline Kim 2009 & FOLFOX vs irinotecan & $\begin{array}{l}0.92 \text { ( } 0.79 \text { to } \\
1.07)\end{array}$ & $\begin{array}{l}0.72 \text { ( } 0.60 \text { to } \\
0.88)\end{array}$ & $\begin{array}{l}1.80(1.26 \text { to } \\
2.56)\end{array}$ & $\begin{array}{l}1.13 \text { (0.99 to } \\
1.29)\end{array}$ \\
\hline Liu 2015 & $\begin{array}{l}\text { Panitumumab + bevacizumab + } \\
\text { FOLFIRI vs FOLFIRI }\end{array}$ & $\begin{array}{l}0.67(0.47 \text { to } \\
0.96)\end{array}$ & $\begin{array}{l}0.58(0.35 \text { to } \\
0.95)\end{array}$ & $\begin{array}{l}1.66(1.03 \text { to } \\
2.67)\end{array}$ & $\begin{array}{l}1.60(1.30 \text { to } \\
1.99)\end{array}$ \\
\hline Masi 2015 & $\begin{array}{l}\text { Bevacizumab + chemotherapy vs } \\
\text { chemotherapy }\end{array}$ & $\begin{array}{l}0.77(0.56 \text { to } \\
1.06)\end{array}$ & $\begin{array}{l}0.70(0.52 \text { to } \\
0.94)\end{array}$ & $\begin{array}{l}1.24(0.70 \text { to } \\
2.19)\end{array}$ & $\begin{array}{l}1.05(0.75 \text { to } \\
1.47)\end{array}$ \\
\hline Muro 2010 & IRIS vs FOLFIRI & $\begin{array}{l}0.91(0.71 \text { to } \\
1.16)\end{array}$ & $\begin{array}{l}1.08(0.86 \text { to } \\
1.34)\end{array}$ & $\begin{array}{l}1.13(0.72 \text { to } \\
1.77)\end{array}$ & $\begin{array}{l}1.00(0.84 \text { to } \\
1.18)\end{array}$ \\
\hline O'Neil 2014 & $\begin{array}{l}\text { Linifanib + FOLFOX vs bevacizumab + } \\
\text { FOLFOX }\end{array}$ & $\begin{array}{l}1.42(0.94 \text { to } \\
2.15)\end{array}$ & $\begin{array}{l}1.45(0.83 \text { to } \\
2.53)\end{array}$ & $\begin{array}{l}0.69(0.37 \text { to } \\
1.29)\end{array}$ & $\begin{array}{l}1.24(1.01 \text { to } \\
1.53)\end{array}$ \\
\hline Peeters 2010 & Panitumumab + FOLFIRI vs FOLFIRI & $\begin{array}{l}0.85(0.70 \text { to } \\
1.03)\end{array}$ & $\begin{array}{l}0.73(0.59 \text { to } \\
0.90)\end{array}$ & $\begin{array}{l}3.44(2.36 \text { to } \\
5.02)\end{array}$ & $\begin{array}{l}1.40(1.23 \text { to } \\
1.60)\end{array}$ \\
\hline Peeters 2013 & Trebananib + FOLFIRI vs FOLFIRI & $\begin{array}{l}0.90 \text { (0.53 to } \\
1.53)\end{array}$ & $\begin{array}{l}1.23 \text { (0.81 to } \\
1.87)\end{array}$ & $\begin{array}{l}13.02 \text { (0.79 to } \\
215.40)\end{array}$ & $\begin{array}{l}0.94 \text { (0.73 to } \\
1.22)\end{array}$ \\
\hline Price 2014 & Panitumumab vs cetuximab & $\begin{array}{l}0.97 \text { ( } 0.84 \text { to } \\
1.12)\end{array}$ & $\begin{array}{l}1.00 \text { (0.88 to } \\
1.14)\end{array}$ & $\begin{array}{l}1.11 \text { ( } 0.87 \text { to } \\
1.42)\end{array}$ & $\begin{array}{l}1.06 \text { (0.93 to } \\
1.20)\end{array}$ \\
\hline $\begin{array}{l}\text { Rothenberg } \\
\text { 2003_folfox }\end{array}$ & FOLFOX vs $5 F U$ & Not available & $\begin{array}{l}0.55(0.43 \text { to } \\
0.70)\end{array}$ & $\begin{array}{l}5.22(1.83 \text { to } \\
14.83)\end{array}$ & $\begin{array}{l}1.78 \text { (1.43 to } \\
2.22)\end{array}$ \\
\hline $\begin{array}{l}\text { Rothenberg } \\
\text { 2003_oxa }\end{array}$ & Oxaliplatin vs 5FU & Not available & $\begin{array}{l}1.11 \text { (0.93 to } \\
1.33)\end{array}$ & $\begin{array}{l}1.29 \text { ( } 0.35 \text { to } \\
4.72)\end{array}$ & $\begin{array}{l}1.14 \text { (0.88 to } \\
1.48)\end{array}$ \\
\hline $\begin{array}{l}\text { Rothenberg } \\
2008\end{array}$ & XELOX vs FOLFOX & $\begin{array}{l}1.02 \text { ( } 0.86 \text { to } \\
1.22)\end{array}$ & $\begin{array}{l}0.97 \text { ( } 0.83 \text { to } \\
1.13)\end{array}$ & $\begin{array}{l}1.11 \text { (0.60 to } \\
2.07)\end{array}$ & $\begin{array}{l}0.75 \text { (0.68 to } \\
0.82)\end{array}$ \\
\hline
\end{tabular}


Table 3. Summary of studies' results (Continued)

\begin{tabular}{|c|c|c|c|c|c|}
\hline Rougier 1998 & Irinotecan vs $5 \mathrm{FU}$ & $\begin{array}{l}0.69 \text { ( } 0.51 \text { to } \\
0.94)\end{array}$ & $\begin{array}{l}0.69 \text { ( } 0.49 \text { to } \\
0.97)\end{array}$ & $\begin{array}{l}2.90(1.27 \text { to } \\
6.62)\end{array}$ & $\begin{array}{l}1.28(1.05 \text { to } \\
1.55)\end{array}$ \\
\hline $\begin{array}{l}\text { Scheithauer } \\
2002\end{array}$ & $\begin{array}{l}\text { Mitomycin + oxaliplatin vs mitomycin } \\
+ \text { irinotecan }\end{array}$ & Not available & Not available & $\begin{array}{l}1.32(0.47 \text { to } \\
3.71)\end{array}$ & $\begin{array}{l}1.62(0.93 \text { to } \\
2.83)\end{array}$ \\
\hline Seymour 2013 & $\begin{array}{l}\text { Panitumumab + irinotecan vs irinote- } \\
\text { can }\end{array}$ & $\begin{array}{l}1.01(0.83 \text { to } \\
1.23)\end{array}$ & $\begin{array}{l}0.78(0.64 \text { to } \\
0.95)\end{array}$ & $\begin{array}{l}2.93(1.97 \text { to } \\
4.35)\end{array}$ & $\begin{array}{l}1.51(1.24 \text { to } \\
1.84)\end{array}$ \\
\hline $\begin{array}{l}\text { Shoemaker } \\
2004\end{array}$ & $\begin{array}{l}\text { Single-dose irinotecan vs fractionat- } \\
\text { ed irinotecan }\end{array}$ & Not available & Not available & $\begin{array}{l}0.62(0.11 \text { to } \\
3.53)\end{array}$ & $\begin{array}{l}0.97(0.72 \text { to } \\
1.30)\end{array}$ \\
\hline Sobrero 2008 & Cetuximab + irinotecan vs irinotecan & $\begin{array}{l}0.98 \text { (0.85 to } \\
1.11)\end{array}$ & $\begin{array}{l}0.69(0.62 \text { to } \\
0.78)\end{array}$ & $\begin{array}{l}3.94(2.62 \text { to } \\
5.92)\end{array}$ & $\begin{array}{l}1.42(1.28 \text { to } \\
1.59)\end{array}$ \\
\hline $\begin{array}{l}\text { Tabernero } \\
2015\end{array}$ & Ramucirumab + FOLFIRI vs FOLFIRI & $\begin{array}{l}0.84(0.73 \text { to } \\
0.97)\end{array}$ & $\begin{array}{l}0.79(0.70 \text { to } \\
0.90)\end{array}$ & $\begin{array}{l}1.07(0.79 \text { to } \\
1.47)\end{array}$ & $\begin{array}{l}1.15(0.97 \text { to } \\
1.36)\end{array}$ \\
\hline Tsavaris 2003 & $\begin{array}{l}\text { Single-dose irinotecan vs fractionat- } \\
\text { ed irinotecan }\end{array}$ & $\begin{array}{l}0.78(0.60 \text { to } \\
1.01)\end{array}$ & $\begin{array}{l}0.75(0.53 \text { to } \\
1.06)\end{array}$ & $\begin{array}{l}0.87(0.45 \text { to } \\
1.66)\end{array}$ & $\begin{array}{l}0.98(0.82 \text { to } \\
1.17)\end{array}$ \\
\hline $\begin{array}{l}\text { Van Cutsem } \\
2011\end{array}$ & Vatalanib + FOLFOX vs FOLFOX & $\begin{array}{l}1.00(0.87 \text { to } \\
1.15)\end{array}$ & $\begin{array}{l}0.83(0.71 \text { to } \\
0.97)\end{array}$ & Not available & $\begin{array}{l}1.19(1.10 \text { to } \\
1.28)\end{array}$ \\
\hline $\begin{array}{l}\text { Van Cutsem } \\
2012\end{array}$ & Aflibercept + FOLFIRI vs FOLFIRI & $\begin{array}{l}0.82(0.71 \text { to } \\
0.94)\end{array}$ & $\begin{array}{l}0.76 \text { ( } 0.66 \text { to } \\
0.87)\end{array}$ & $\begin{array}{l}1.78(1.32 \text { to } \\
2.39)\end{array}$ & $\begin{array}{l}1.34(1.24 \text { to } \\
1.43)\end{array}$ \\
\hline Viéitez 2011 & Gefitinib + raltitrexed vs raltitrexed & $\begin{array}{l}0.99(0.55 \text { to } \\
1.78)\end{array}$ & $\begin{array}{l}1.23(0.81 \text { to } \\
1.87)\end{array}$ & $\begin{array}{l}1.00(0.15 \text { to } \\
6.74)\end{array}$ & $\begin{array}{l}1.67(0.43 \text { to } \\
6.49)\end{array}$ \\
\hline
\end{tabular}

$\mathrm{Cl}$ : confidence interval; FOLFIRI: fluorouracil + irinotecan + leucovorin; FOLFOX: fluorouracil + oxaliplatin + leucovorin; HR: hazard ratio; ORR: overall response rate; OS: overall survival; PFS: progression-free survival; RR: risk ratio; SAE: severe adverse effects.

\section{APPEN DICES}

\section{Appendix 1. CENTRAL search strategy}

\section{CENTRAL search strategy 2016, Issue 4}

\#1 MeSH descriptor: [Colorectal Neoplasms] explode all trees

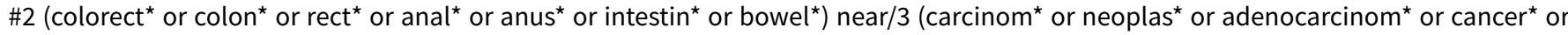
tumor* or tumour* or sarcom*):ti,ab,kw

\#3 \#1 or \#2

\#4 MeSH descriptor: [Chemotherapy, Adjuvant] explode all trees

\#5 MeSH descriptor: [Salvage Therapy] explode all trees

\#6 MeSH descriptor: [Drug Resistance] explode all trees

\#7 chemotherap* or salvage therapy or drug resistance:ti,ab,kw

\#8 MeSH descriptor: [Antibodies, Monoclonal, Humanized] explode all trees

\#9 MeSH descriptor: [Receptor, Epidermal Growth Factor] explode all trees

\#10 MeSH descriptor: [Receptors, Vascular Endothelial Growth Factor] explode all trees 
\#11 MeSH descriptor: [Protein Kinase Inhibitors] explode all trees

\#12 MeSH descriptor: [Antineoplastic Combined Chemotherapy Protocols] explode all trees

\#13 (vascular endothelial growth factor or VEGF or VEGFR or FGFR or fibroblast growth factor or target* therap* or antibod* or tyrosine kinase receptor inhibitor or oxaliplatin or cetuximab or irinotecan or camptothecin or protein kinase inhibitor or capecitabine or fluorouracil or leucovorin or conatumumab or panituzumab or bevacizumab or raltitrexed or aflibercept or sorafenib or cediranib or axitinib)

$\# 14 \# 4$ or \#5 or \#6 or \#7 or \#8 or \#9 or \#10 or \#11 or \#12 or \#13

\#15 (second line or second-line)

$\# 16 \# 14$ and \#15

\#17 ((resistant or refractory) adj5 (cisplatin or carboplatin or anthracycline or doxorubicin or platinum))

$\# 18 \# 16$ or \#17

$\# 19 \# 3$ and \#18

\section{Appendix 2. MEDLINE search strategy}

\section{Ovid MEDLINE 1950 to 18 May 2016}

1. exp Colorectal Neoplasms/

2. ((colorect ${ }^{\star}$ or colon ${ }^{\star}$ or rect ${ }^{\star}$ or anal ${ }^{\star}$ or anus ${ }^{\star}$ or intestin ${ }^{\star}$ or bowel ${ }^{\star}$ ) adj3 (carcinom ${ }^{\star}$ or neoplas or adenocarcinom $^{\star}$ or cancer $^{\star}$ or tumor ${ }^{\star}$ or tumour ${ }^{\star}$ or sarcom*)).mp.

3. 1 or 2

4. exp Salvage Therapy/

5. exp Drug Resistance/

6. (chemotherap* or salvage therapy or drug resistance).mp.

7. Antibodies/ or exp Antibodies, Monoclonal, Humanized/

8. exp Epidermal Growth Factor/

9. exp Vascular Endothelial Growth Factors/

10. exp Protein Kinase Inhibitors/

11. exp Antineoplastic Combined Chemotherapy Protocols/

12. (vascular endothelial growth factor or VEGF or VEGFR or FGFR or fibroblast growth factor or epidermal growth factor or EGR or EGFR or ErbB-1 or HER1).mp.

13. (target ${ }^{\star}$ therap* or antibod* or tyrosine kinase receptor inhibitor or oxaliplatin or cetuximab or irinotecan or camptothecin or protein kinase inhibitor or capecitabine or fluorouracil or leucovorin or conatumumab or panituzumab or bevacizumab or raltitrexed or aflibercept or sorafenib or cediranib or axitinib).mp.

14. or/4-13

15. (second line or second-line).mp.

16. 14 and 15

17. ((resistant or refractory) adj5 (cisplatin or carboplatin or anthracycline or doxorubicin or platinum)).mp.

18. 16 or 17

19. 3 and 18

20. randomized controlled trial.pt. 
21. controlled clinical trial.pt.

22. randomized.ab.

23. placebo.ab.

24. clinical trials as topic.sh.

25. randomly.ab.

26. trial.ti.

27.20 or 21 or 22 or 23 or 24 or 26

28. exp animals/ not humans.sh.

29. 27 not 28

30. 19 and 29

\section{Appendix 3. MEDLINE In-process \& Other Non-Indexed Citations search strategy}

\section{Ovid MEDLINE In-process \& Other Non-indexed Citations 1946 to 18 May 2016}

1. exp Colorectal Neoplasms/

2. ((colorect* or colon ${ }^{\star}$ or rect ${ }^{\star}$ or anal ${ }^{\star}$ or anus ${ }^{\star}$ or intestin* or bowel $\left.^{\star}\right)$ adj3 $\left(\right.$ carcinom $^{\star}$ or neoplas or adenocarcinom $^{\star}$ or cancer or $^{\star}$ tumor $^{\star}$ or tumour ${ }^{\star}$ or sarcom*)).mp.

3. 1 or 2

4. exp Salvage Therapy/

5. exp Drug Resistance/

6. (chemotherap^ or salvage therapy or drug resistance).mp.

7. Antibodies/ or exp Antibodies, Monoclonal, Humanized/

8. exp Epidermal Growth Factor/

9. exp Vascular Endothelial Growth Factors/

10. exp Protein Kinase Inhibitors/

11. exp Antineoplastic Combined Chemotherapy Protocols/

12. (vascular endothelial growth factor or VEGF or VEGFR or FGFR or fibroblast growth factor or epidermal growth factor or EGR or EGFR or ErbB-1 or HER1).mp.

13. (target $^{\star}$ therap $^{\star}$ or antibod ${ }^{\star}$ or tyrosine kinase receptor inhibitor or oxaliplatin or cetuximab or irinotecan or camptothecin or protein kinase inhibitor or capecitabine or fluorouracil or leucovorin or conatumumab or panituzumab or bevacizumab or raltitrexed or aflibercept or sorafenib or cediranib or axitinib).mp.

14. or/4-13

15. (second line or second-line).mp.

16. 14 and 15

17. ((resistant or refractory) adj5 (cisplatin or carboplatin or anthracycline or doxorubicin or platinum)).mp.

18. 16 or 17

19. 3 and 18

20. random* or placebo or trial or blind ${ }^{\star}$ or meta-analys ${ }^{\star}$ or meta analys ${ }^{\star}$

21. 19 and 20

Second-line systemic therapy for metastatic colorectal cancer (Review)

Copyright ๑ 2017 The Cochrane Collaboration. Published by John Wiley \& Sons, Ltd. 


\section{Appendix 4. EMBASE search strategy}

\section{Ovid EMBASE 1974 to 18 May 2016}

1. exp colon tumor/

2. exp rectum tumor/

3. ((colorect ${ }^{\star}$ or colon ${ }^{\star}$ or rect ${ }^{\star}$ or anal ${ }^{\star}$ or anus ${ }^{\star}$ or intestin* or bowel $\left.^{\star}\right)$ adj3 (carcinom ${ }^{\star}$ or neoplas ${ }^{\star}$ or adenocarcinom ${ }^{\star}$ or cancer $^{\star}$ or $^{*}$ tumor $^{\star}$ or tumour $^{\star}$ or sarcom*)).mp.

4. 1 or 2 or 3

5. $\exp$ CHEMOTHERAPY/

6. exp salvage therapy/

7. exp drug resistance/

8. (chemotherap* or salvage therapy or drug resistance).mp.

9. exp monoclonal antibody/ or antibody/

10. exp epidermal growth factor/

11. (vascular endothelial growth factor or VEGF or VEGFR or FGFR or fibroblast growth factor or epidermal growth factor or EGR or EGFR or ErbB-1 or HER1).mp.

12. exp protein kinase inhibitor/

13. exp antineoplastic agent/

14. (target* therap* or antibod* or tyrosine kinase receptor inhibitor or oxaliplatin or cetuximab or irinotecan or camptothecin or protein kinase inhibitor or capecitabine or fluorouracil or leucovorin or conatumumab or panituzumab or bevacizumab or raltitrexed or aflibercept or sorafenib or cediranib or axitinib).mp.

15. or/5-14

16. (second line or second-line).mp.

17. 15 and 16

18. ((resistant or refractory) adj5 (cisplatin or carboplatin or anthracycline or doxorubicin or platinum)).mp.

19. 17 or 18

20. 4 and 19

21. CROSSOVER PROCEDURE.sh.

22. DOUBLE-BLIND PROCEDURE.sh.

23. SINGLE-BLIND PROCEDURE.sh.

24. (crossover ${ }^{\star}$ or cross over $\left.{ }^{\star}\right)$.ti,ab.

25. placebo*.ti,ab.

26. (doubl ${ }^{\star}$ adj blind $\left.{ }^{\star}\right)$.ti,ab.

27. allocat ${ }^{\star} \cdot \mathrm{ti}, \mathrm{ab}$.

28. trial.ti.

29. RANDOMIZED CONTROLLED TRIAL.sh.

30. random*.ti,ab.

31.21 or 22 or 23 or 24 or 25 or 26 or 27 or 28 or 29 or 30

Second-line systemic therapy for metastatic colorectal cancer (Review) 
32. (exp animal/ or exp invertebrate/ or animal.hw. or nonhuman/) not (exp human/ or human cell/ or (human or humans or man or men or women).ti.)

33. 31 not 32

34. 20 and 33

Appendix 5. Criteria for judging risk of bias in the 'Risk of bias' assessment tool

\section{Random sequence generation}

Selection bias (biased allocation to interventions) due to inadequate generation of a randomized sequence.

Criteria for a judgement of 'low risk' of bias.
The investigators describe a random component in the sequence generation process such as:

- referring to a random number table;

- using a computer random number generator;

- coin tossing;

- shuffling cards or envelopes;

- throwing dice;

- drawing of lots;

- minimization*.

*Minimization may be implemented without a random element, and this is considered to be equivalent to being random.

Criteria for the judgement of 'high risk' of bias.
The investigators describe a non-random component in the sequence generation process. Usually, the description would involve some systematic, non-random approach, for example:

- sequence generated by odd or even date of birth;

- sequence generated by some rule based on date (or day) of admission;

- sequence generated by some rule based on hospital or clinic record number;

- Other non-random approaches happen much less frequently than the systematic approaches mentioned above and tend to be obvious. They usually involve judgement or some method of non-random categorization of participants, for example:

- allocation by judgement of the clinician;

- allocation by preference of the participant;

- allocation based on the results of a laboratory test or a series of tests;

- allocation by availability of the intervention.
Criteria for the judgement of 'unclear risk' of bias.
Insufficient information about the sequence generation process to permit judgement of 'low risk' or 'high risk'.

\section{Allocation concealment}

Selection bias (biased allocation to interventions) due to inadequate concealment of allocations prior to assignment.

Criteria for a judgement of 'low risk' of bias.
Participants and investigators enrolling participants could not foresee assignment because 1 of the following, or an equivalent method, was used to conceal allocation:

- central allocation (including telephone, web-based and pharmacy-controlled randomization);

- sequentially numbered drug containers of identical appearance;

- sequentially numbered, opaque, sealed envelopes.
Criteria for the judgement of 'high risk' of bias.
Participants or investigators enrolling participants could possibly foresee assignments and thus introduce selection bias, such as allocation based on:

- using an open random allocation schedule (e.g. a list of random numbers); 
- assignment envelopes were used without appropriate safeguards (e.g. if envelopes were unsealed or nonopaque or not sequentially numbered);

- alternation or rotation;

- date of birth;

- case record number;

- any other explicitly unconcealed procedure.

Criteria for the judgement of 'unclear risk' of bias.
Insufficient information to permit judgement of 'low risk' or 'high risk'. This is usually the case if the method of concealment is not described or not described in sufficient detail to allow a definite judgement - for example, if the use of assignment envelopes is described, but it remains unclear whether envelopes were sequentially numbered, opaque and sealed.

\section{Blinding of participants and personnel}

Performance bias due to knowledge of the allocated interventions by participants and personnel during the study.

$\begin{array}{ll}\begin{array}{l}\text { Criteria for a judgement of } \\ \text { 'low risk' of bias. }\end{array} & \text { Any } 1 \text { of the following: } \\ & \text { no blinding or incomplete blinding, but the review authors judge that the outcome is not likely to } \\ \text { be influenced by lack of blinding; } & \text { blinding of participants and key study personnel ensured, and unlikely that the blinding could } \\ & \text { have been broken. }\end{array}$

Criteria for the judgement of 'high risk' of bias.

\section{Any 1 of the following:}

- no blinding or incomplete blinding, and the outcome is likely to be influenced by lack of blinding

- blinding of key study participants and personnel attempted, but likely that the blinding could have been broken, and the outcome is likely to be influenced by lack of blinding.

\section{Criteria for the judgement of} 'unclear risk' of bias.

\section{Any 1 of the following:}

- insufficient information to permit judgement of 'low risk' or 'high risk';

- the study did not address this outcome.

\section{Blinding of outcome assessment}

Detection bias due to knowledge of the allocated interventions by outcome assessors.

\section{Criteria for a judgement of} 'low risk' of bias.

\section{Any 1 of the following:}

- no blinding of outcome assessment, but the review authors judge that the outcome measurement is not likely to be influenced by lack of blinding;

- blinding of outcome assessment ensured, and unlikely that the blinding could have been broken.

\section{Criteria for the judgement of} 'high risk' of bias.

\section{Any 1 of the following:}

- no blinding of outcome assessment, and the outcome measurement is likely to be influenced by lack of blinding;

- blinding of outcome assessment, but likely that the blinding could have been broken, and the outcome measurement is likely to be influenced by lack of blinding.

\author{
Criteria for the judgement of \\ 'unclear risk' of bias.
}

\section{Any 1 of the following:}

- insufficient information to permit judgement of 'low risk' or 'high risk';

- the study did not address this outcome.

\section{lincomplete outcome data}

Attrition bias due to amount, nature or handling of incomplete outcome data. 
(Continued)

Criteria for a judgement of 'low risk' of bias.
Any 1 of the following:

- no missing outcome data;

- reasons for missing outcome data unlikely to be related to true outcome (for survival data, censoring unlikely to be introducing bias);

- missing outcome data balanced in numbers across intervention groups, with similar reasons for missing data across groups;

- for dichotomous outcome data, the proportion of missing outcomes compared with observed event risk not enough to have a clinically relevant impact on the intervention effect estimate;

- for continuous outcome data, plausible effect size (difference in means or standardized difference in means) among missing outcomes not enough to have a clinically relevant impact on observed effect size;

- missing data have been imputed using appropriate methods.
Criteria for the judgement of high risk' of bias.
Any 1 of the following:

- reason for missing outcome data likely to be related to true outcome, with either imbalance in numbers or reasons for missing data across intervention groups;

- for dichotomous outcome data, the proportion of missing outcomes compared with observed event risk enough to induce clinically relevant bias in intervention effect estimate;

- for continuous outcome data, plausible effect size (difference in means or standardized difference in means) among missing outcomes enough to induce clinically relevant bias in observed effect size;

- 'as-treated' analysis done with substantial departure of the intervention received from that assigned at randomization;

- potentially inappropriate application of simple imputation.
Criteria for the judgement of 'unclear risk' of bias.
Any 1 of the following:

- insufficient reporting of attrition/exclusions to permit judgement of 'low risk' or 'high risk' (e.g. number randomized not stated, no reasons for missing data provided);

- the study did not address this outcome.

\section{Selective reporting}

Reporting bias due to selective outcome reporting.

Criteria for a judgement of 'low risk' of bias.

\section{Any of the following:}

- the study protocol is available and all of the study's prespecified (primary and secondary) outcomes that are of interest in the review have been reported in the prespecified way;

- the study protocol is not available but it is clear that the published reports include all expected outcomes, including those that were prespecified (convincing text of this nature may be uncommon).
Criteria for the judgement of 'high risk' of bias.
Any 1 of the following:

- not all of the study's prespecified primary outcomes have been reported;

- 1 or more primary outcomes is reported using measurements, analysis methods or subsets of the data (e.g. subscales) that were not prespecified;

- 1 or more reported primary outcomes were not prespecified (unless clear justification for their reporting is provided, such as an unexpected adverse effect);

- 1 or more outcomes of interest in the review are reported incompletely so that they cannot be entered in a meta-analysis;

- the study report does not include results for a key outcome that would be expected to have been reported for such a study. 
(Continued)

Criteria for the judgement of 'unclear risk' of bias.
Insufficient information to permit judgement of 'low risk' or 'high risk'. It is likely that the majority of studies will fall into this category.

\section{Other bias}

Bias due to problems not covered elsewhere in the table.

\section{Criteria for a judgement of The study appears to be free of other sources of bias.}

'low risk' of bias.

Criteria for the judgement of

'high risk' of bias.
There is at least 1 important risk of bias. For example, the study:

- had a potential source of bias related to the specific study design used; or

- has been claimed to have been fraudulent; or

- had some other problem.
Criteria for the judgement of 'unclear risk' of bias.
There may be a risk of bias, but there is either:

- insufficient information to assess whether an important risk of bias exists; or

- insufficient rationale or evidence that an identified problem will introduce bias.

\section{WHAT'S NEW}

\begin{tabular}{lll}
\hline Date & Event & Description \\
\hline 18 May 2016 & $\begin{array}{l}\text { New citation required and conclusions } \\
\text { have changed }\end{array}$ & $\begin{array}{l}\text { New search performed and 27 new studies incorporated in the } \\
\text { review. }\end{array}$ \\
\hline
\end{tabular}

\section{H I S T O R Y}

Protocol first published: Issue 1, 2008

Review first published: Issue 2, 2009

\begin{tabular}{lll}
\hline Date & Event & Description \\
\hline 5 December 2008 & Amended & Substantive amendment: review finalised \\
\hline 14 May 2008 & Amended & Converted to new review format. \\
\hline 16 September 2007 & $\begin{array}{l}\text { New citation required and major } \\
\text { changes }\end{array}$ & Substantive amendment \\
\hline
\end{tabular}

\section{CONTRIBUTIONSOF AUTHORS}

Previous version: MR wrote the draft protocol; IS designed the search strategy; all authors helped design the review and write the review. Current version: SM and ZB updated and expanded (including targeted therapies) the previous version.

\section{DECLARATIONS OF INTEREST}

None of the authors have any known conflicts of interest to declare. 


\section{SOURCES OF SUPPORT}

\section{Internal sources}

- No sources of support supplied

\section{External sources}

- Instituto de Salud Carlos III. PI04/2309, Spain.

\section{DIFFERENCES BETWEEN PROTOCOL AND REVIEW}

The updated version included targeted therapies (which were excluded in the previous version of the protocol and review): overall, this led to the inclusion of 34 trials instead of the seven trials included in the previous version.

Future updates of this review will include targeted therapies.

\section{N DEX TERMS}

\section{Medical Subject Headings (MeSH)}

Antineoplastic Agents [ ${ }^{*}$ therapeutic use]; Antineoplastic Combined Chemotherapy Protocols [administration \& dosage] [*therapeutic use]; Bevacizumab [administration \& dosage]; Camptothecin [administration \& dosage] [analogs \& derivatives] [therapeutic use]; Colorectal Neoplasms [ ${ }^{*}$ drug therapy] [mortality] [pathology]; Fluorouracil [administration \& dosage]; Irinotecan; Leucovorin [administration \& dosage]; Organoplatinum Compounds [administration \& dosage]; Randomized Controlled Trials as Topic; Survival Rate

\section{MeSH check words}

Humans 